\title{
Peroxides with Anthelmintic, Antiprotozoal, Fungicidal and Antiviral Bioactivity: Properties, Synthesis and Reactions
}

\author{
Vera A. Vil' 1,2,3, Ivan A. Yaremenko ${ }^{1,2,3}$, Alexey I. Ilovaisky ${ }^{1}$ and Alexander O. Terent'ev ${ }^{1,2,3, *}$ \\ 1 N. D. Zelinsky Institute of Organic Chemistry, Russian Academy of Sciences, 47 Leninsky Prospekt, \\ 119991 Moscow, Russia; vil@ioc.ac.ru (V.A.V.); yaremenko@ioc.ac.ru (I.A.Y.); ilov@ioc.ac.ru (A.I.I.) \\ 2 Faculty of Chemical and Pharmaceutical Technology and Biomedical Products, D. I. Mendeleev University \\ of Chemical Technology of Russia, 9 Miusskaya Square, 125047 Moscow, Russia \\ 3 All-Russian Research Institute for Phytopathology, B. Vyazyomy, 143050 Moscow, Russia \\ * Correspondence: alterex@yandex.ru; Tel.: +7-916-385-4080
}

Received: 9 October 2017; Accepted: 30 October 2017; Published: 2 November 2017

\begin{abstract}
The biological activity of organic peroxides is usually associated with the antimalarial properties of artemisinin and its derivatives. However, the analysis of published data indicates that organic peroxides exhibit a variety of biological activity, which is still being given insufficient attention. In the present review, we deal with natural, semi-synthetic and synthetic peroxides exhibiting anthelmintic, antiprotozoal, fungicidal, antiviral and other activities that have not been described in detail earlier. The review is mainly concerned with the development of methods for the synthesis of biologically active natural peroxides, as well as its isolation from natural sources and the modification of natural peroxides. In addition, much attention is paid to the substantially cheaper biologically active synthetic peroxides. The present review summarizes 217 publications mainly from 2000 onwards.
\end{abstract}

Keywords: peroxides; anthelmintic; antiprotozoal; fungicidal; antiviral

\section{Introduction}

Peroxides are widely used in various areas of life [1-3]. Traditional and the most developed field is the application of peroxides as radical initiators in industrial processes in the manufacture of polymers from unsaturated monomers: styrenes, butadienes, chlorovinyls, ethylenes, acrylates, as well as in crosslinking of silicone rubbers, acrylonitrile-butadiene rubbers, fluororubbers, polyethylene, ethylene-propylene copolymer, etc. [4-9].

Hydrogen peroxide and peracids are active components of antiseptics and disinfectants [10-14]. Synthesis and mechanism of antiseptic action of hydrogen peroxide and the most common peracids (performic, peracetic, etc.) are elucidated in a few studies [15-17] and are not considered in this review.

Antimalarial properties of peroxides are currently intensively studied. Artemisinin (Qinghaosu) (1), a natural peroxide possessing high antimalarial activity, was isolated in 1971 from leaves of annual wormwood (Artemisia annua) in the context of the scientific program "Project 523", initiated by Chinese government in 1967 [18-20]. The Nobel Prize in Physiology or Medicine 2015 was awarded to Chinese pharmaceutical chemist Tu Youyou "for her discoveries concerning a novel therapy against Malaria" [21-23]. Considering the development of antibiotic resistance of Plasmodium to some traditional drugs, such as quinine, chloroquine, and mefloquine, and other anti-parasitic ones, pharmaceuticals based on artemisinin and its semi-synthetic derivatives-dihydroartemisinin (2), artemether (3) and artesunate (4) (Figure 1)-are currently the most effective drugs against malaria [24-30]. 
<smiles>C[C@H]1CC[C@H]2[C@@H](C)C(=O)O[C@@]3(O)O[C@@]4(C)CCC1[C@@]23OO4</smiles>

artemisinin (1)

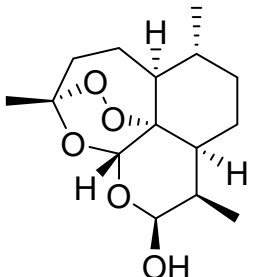

dihydroartemisinin (2)

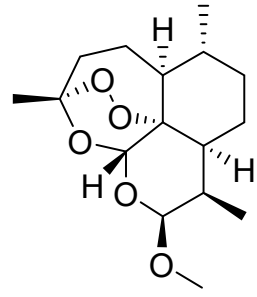

artemether (3)

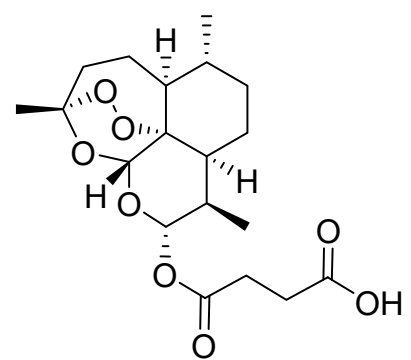

artesunate (4)

Figure 1. Artemisinin and its semi-synthetic derivatives.

The modern trend in medicinal chemistry of peroxides is the search of effective anticancer drugs. The natural and synthetic peroxides exhibiting a cytotoxic effect on cancer cells already include hundreds of compounds [31-34]. Peroxides possessing antimalarial and cytotoxic activity are the subject of numerous studies [35-42], and are not considered in this review.

In the present review, we deal with natural, semi-synthetic and synthetic peroxides exhibiting anthelmintic, antiprotozoal, fungicidal, antiviral and other activities that have not been described in detail earlier. The review is mainly concerned with the synthesis of such peroxides, as well as its isolation from natural sources and covers literature published between 1912 and 2017.

There are several review articles, where the various kinds of the biological activity of artemisinin [43-45] and artemether [46,47]; the problems of trematode infection therapy with artemisinin, its derivatives and several synthetic ozonides [48]; and antiviral activity of artemisinin and artesunate [49] are discussed. Advances in the development of anti-parasitic peroxides are described in the review of Muraleedharan [50]. A number of reviews are devoted to promising anthelmintic peroxides [51]. Some natural antiviral peroxides are mentioned in the review [52]. However, none of these articles pay sufficient attention to the methods of peroxide synthesis.

Since peroxides with a related structure have different types of activity, the systematization of this review is based on the structure of the peroxide fragment (Figure 2). The first sections consider the preparation of cyclic peroxides in order of increasing cycle and the number of oxygen atoms in it, while the last section deals with peroxides of acyclic structure. The following abbreviations are used in describing the biological activity of peroxides: minimum inhibitory concentration (MIC), minimum lethal concentration (MLC), half maximal inhibitory concentration $\left(\mathrm{IC}_{50}\right)$, concentration of inhibiting $90 \%$ of activity $\left(\mathrm{IC}_{90}\right)$, half maximal effective concentration $\left(\mathrm{EC}_{50}\right)$, and median effective dose $\left(\mathrm{ED}_{50}\right)[53,54]$.

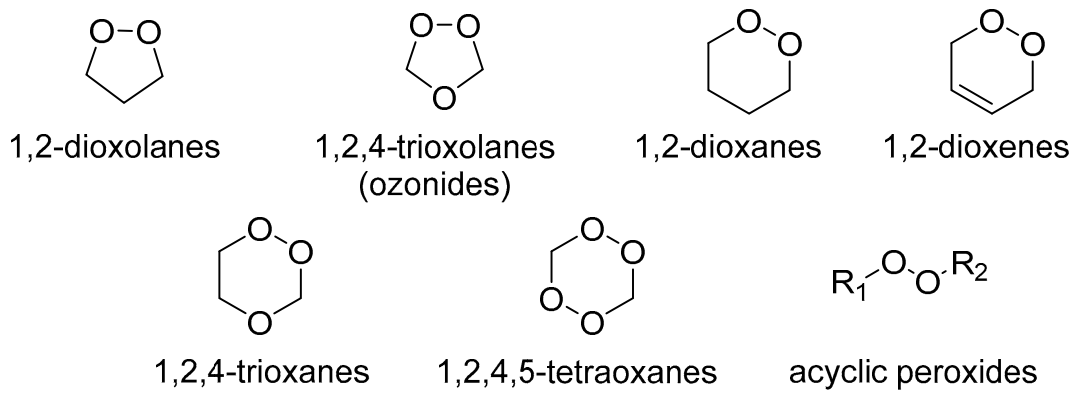

Figure 2. Reviewed cyclic and acyclic peroxides.

\section{1,2-Dioxolanes}

A number of cyclic peroxides, many of which exhibit antibacterial, antifungal and anti-cancer activity, were isolated from the marine organisms, in particular from the sponges Plakinidae [55]. Plakinic acid A (5) effectively inhibits the growth of fungi Saccharomyces cerevisiae and Penicillium atrounenetum [56]; 
plakinic acid F (7) and epi-plakinic acid $\mathrm{F}$ (8) exhibit moderate antifungal activity against Candida albicans and Aspergillus fumigatus [57]; 1,2-dioxolane acids $\mathbf{9}$ and $\mathbf{1 0}$ inhibit the growth of Candida albicans [58]; and plakortide E (11) show good activity against Trypanosoma brucei (Scheme 1) [59].
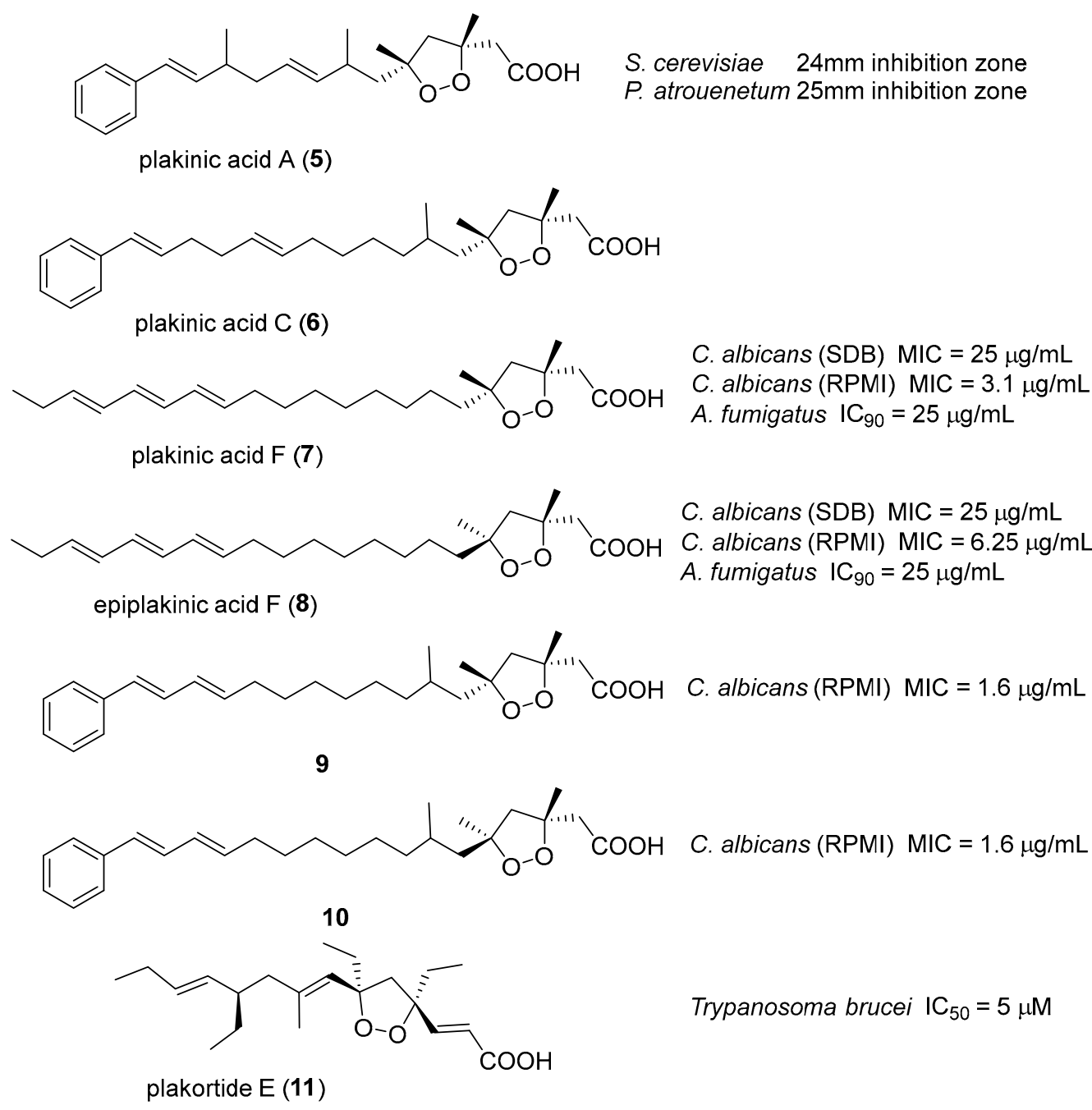

Scheme 1. Antifungal and anti-parasitic activity of 1,2-dioxolanes, isolated from the sponges Plakinidae.

The first synthesis of diastereomeric saturated analogs of plakinic acids A, C and D 17 was reported in 1996 by Bloodworth and colleagues [60]. Peroxides 17 were prepared in four steps from ketones 12. In the first step, ketone 12 was condensed with ethyl 3-methylbut-2-enoate with formation cyclic lactones $\mathbf{1 3}$ hydrolysis, which led to acids $\mathbf{1 4}$. Peroxymercuration of esters $\mathbf{1 5}$ followed by reduction with sodium borohydride afforded 1,2-dioxolanes 16 saponification, which resulted in 1,2-dioxolanes 17 with carboxylic group (Scheme 2).

The synthesis of diastereomeric 1,2-dioxolanes 22 from alkynes was described [61]. Carboalumination of alkyne 18, followed by treatment of the intermediate alkenylaluminum with acetaldehyde, resulted in an allylic alcohol that was oxidized to enone 19. Conjugate addition of $\mathrm{H}_{2} \mathrm{O}_{2}$ to 19 in the presence of $\mathrm{LiOH}$ followed by acid-catalyzed esterification of diastereomeric dioxinole by 2-methoxyethanol provided alkoxydioxolane 20. Substitution of the methoxyethoxy group in $\mathbf{2 0}$ by the action of silyl keteneacetal ethyl thioacetal in the presence of $\mathrm{TiCl}_{4}$ led to thioether 21 as a 1:1 mixture of two diastereomers. The hardly-separable cis- and trans-diastereomeric peroxides $\mathbf{2 2}$ were obtained as a result of hydrolysis with high yield (Scheme 3). 


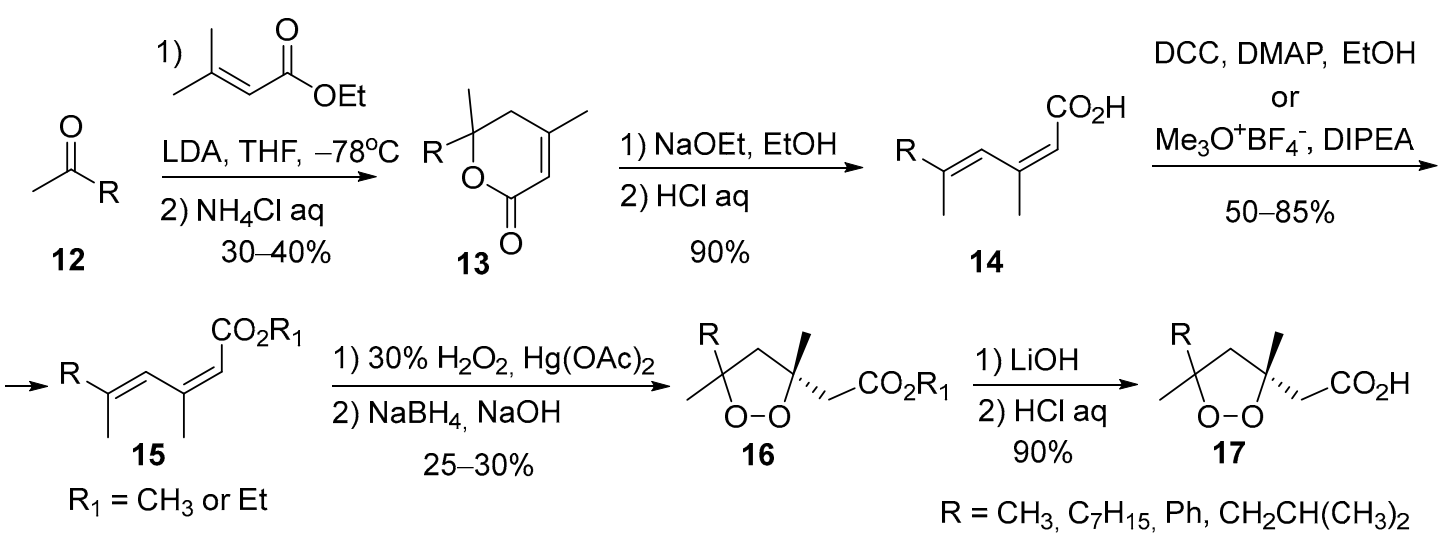

Scheme 2. The first synthesis of saturated analogs of plakinic acids $\mathbf{1 7 .}$

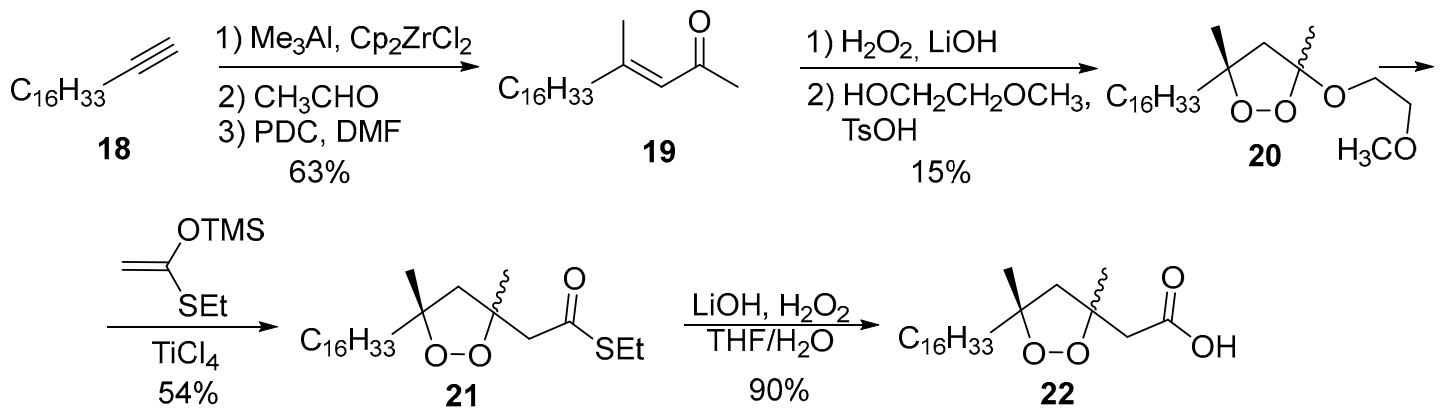

Scheme 3. The synthesis of diastereomeric analogs of plakinic acids 22.

In 2006, the first asymmetric synthesis of plakinic acids was reported [62]. The key step of side chain construction was synthesis of diastereomeric allylic alcohols $\mathbf{2 5}$ from bromobenzene. This transformation included subsequent addition Mg-organic compound to crotonaldehyde with formation of alcohol 23, Claisen homologation resulted in ester $\mathbf{2 4}$, and reaction of an intermediate aldehyde with propenyl lithium (Scheme 4).

As a result of following transformation epoxy alcohol 29a was prepared, which was oxidized into aldehyde; subsequent addition of methylmagnesium bromide resulted in isomeric secondary epoxy alcohols 30a and 30b (Scheme 5). After transformation of minor 30b into 30a, the latter was reduced to diol 31. The treatment of diol $\mathbf{3 1}$ with stoichiometric quantity of $\mathrm{TsCl}$ and excess of $t$-BuOK led to oxetane 32. The ring opening with TMSOTf provided easily separable 3-hydroxy hydroperoxides 33 and epi-33; 33 was converted into peroxy ketone 34 by subsequent silylation and oxidation. The ketone 34 was transformed into alkoxydioxolane 35, and after that into thioester 36 . The desirable plakinic acids $\mathbf{3 8}$ were prepared by hydrolysis of methyl esters $\mathbf{3 7}$. A similar strategy was used for the synthesis of stereomeric acids 39 from 3-hydroxy hydroperoxide epi-33.

A total synthesis of plakortide $\mathrm{E}$ (11) based on radical oxygenation of vinylcyclopropanes was reported [63,64]. The key intermediate 2-ethyl-1,1,2-cyclopropanetricarboxylate (42) prepared from methylene malonate (40) and $\alpha$-chloro ester 41 was transformed into lactone 43 . The treatment of the latter with oxygen, $\mathrm{Ph}_{2} \mathrm{Se}_{2}$ and AIBN furnished spiro 1,2-dioxolane 44, followed by lactone ring opening of 44 to form diol 45. The precursor of the plakortide E 49 was synthesized from the iodo-derivative of 1,2-dioxolane 47 and the halogen derivative 48 by Negishi reaction. Desilylation of alcohol 49 , subsequent oxidation and Horner-Wadsworth-Emmons olefination provided ester $\mathbf{5 1}$ which was hydrolyzed with formation of plakortide E (11) (Scheme 6) [63]. 

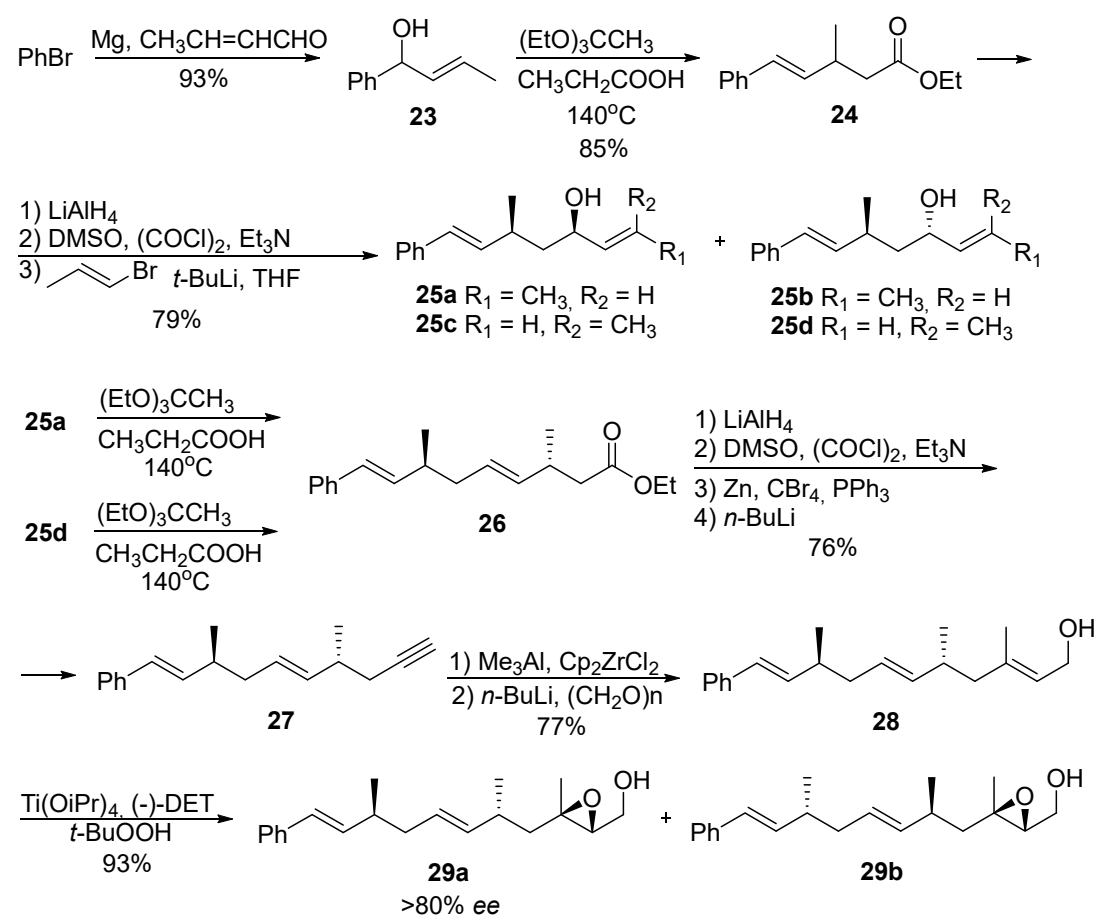

Scheme 4. Construction of asymmetric plakinic acids side chain.

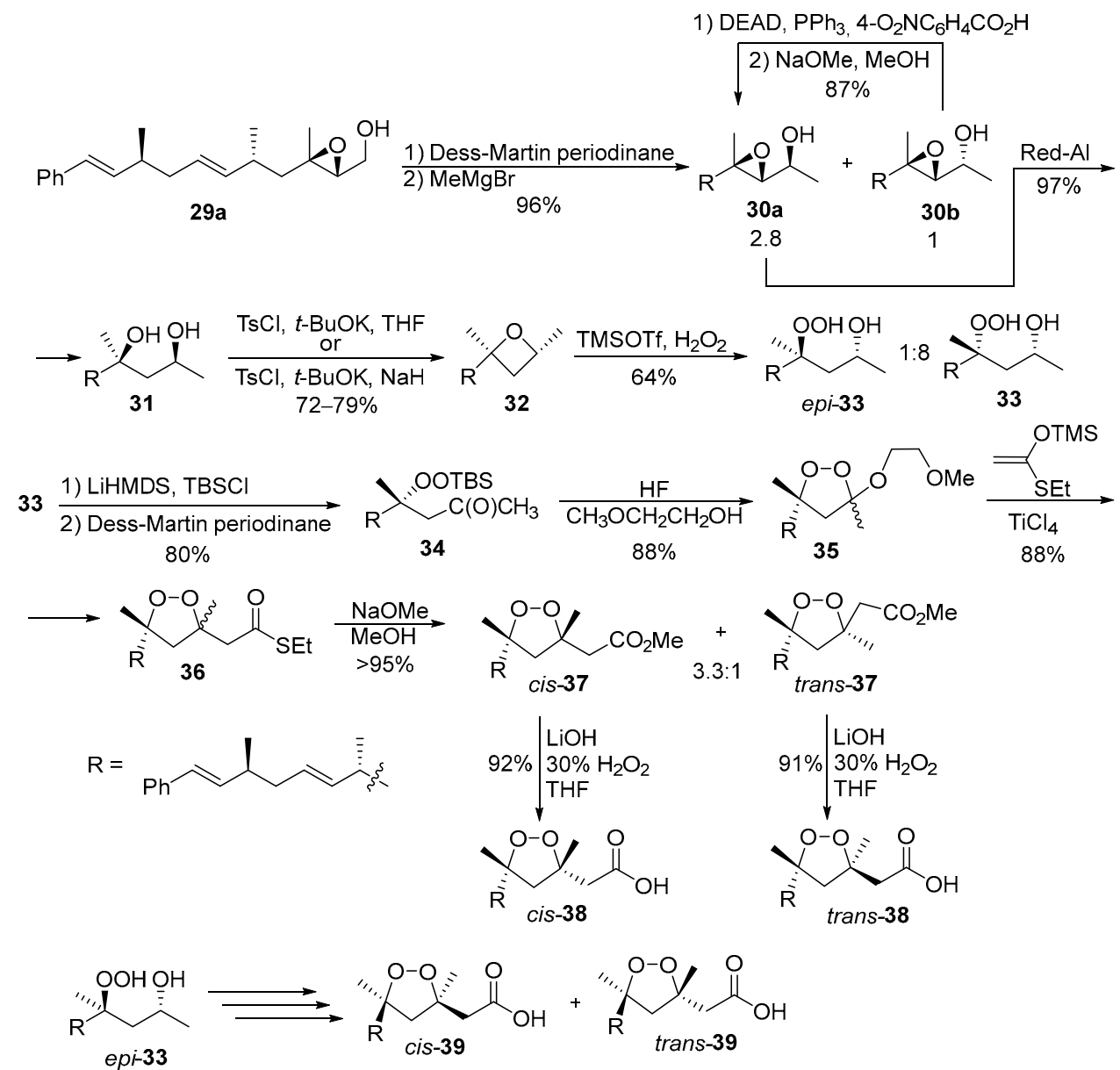

Scheme 5. Asymmetric synthesis of plakinic acids 38 and 39. 


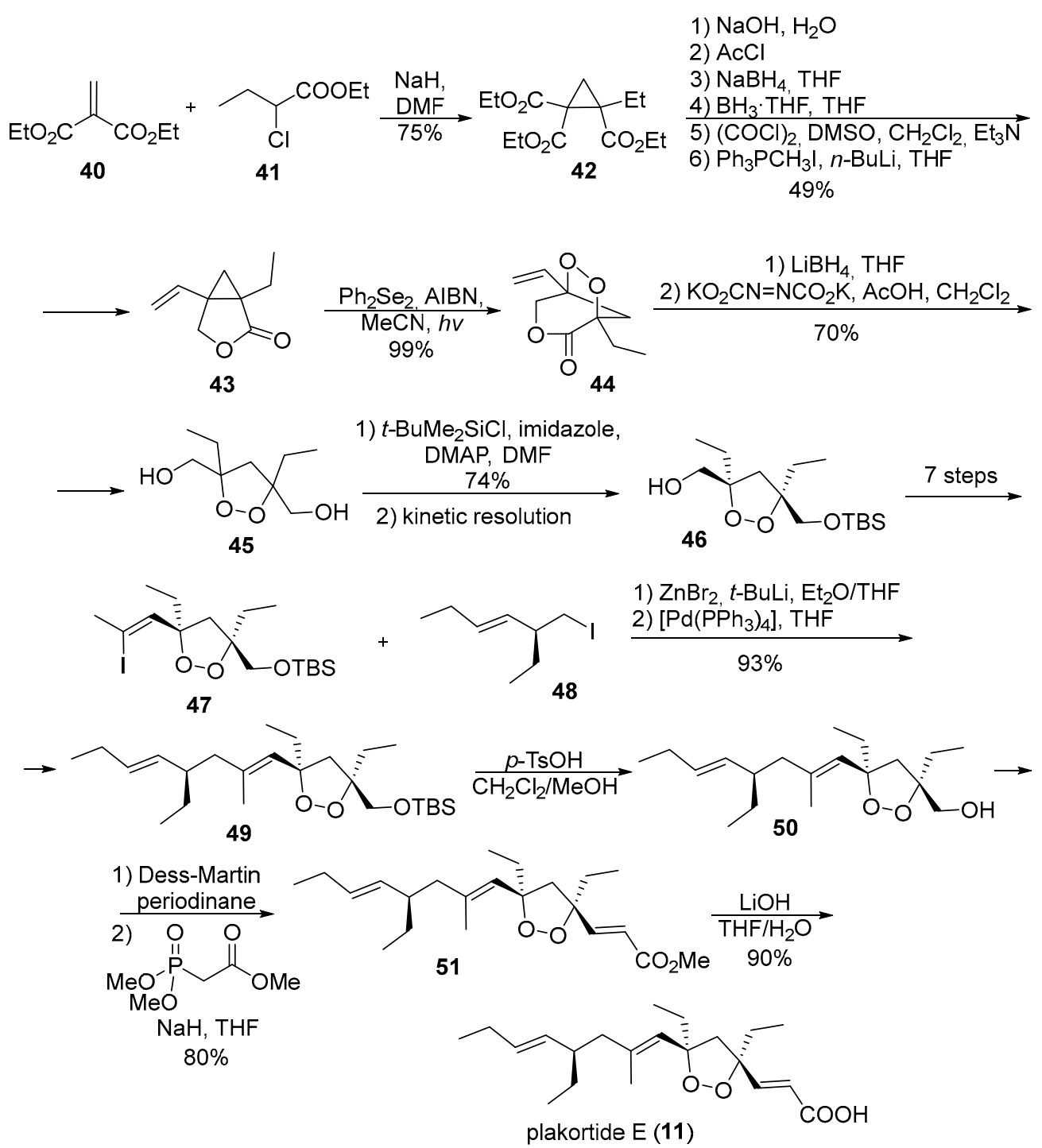

Scheme 6. Synthesis of plakortide E (11) by radical oxygenation of cyclopropanes.

A similar strategy based on the radical oxygenation of vinyl cyclopropanes was used for the synthesis of epiplakinic acid F (8) [65]. The vinyl cyclopropane 53 obtained from trans-1,2-cyclopropanedicarboxylate 52, was then converted to 1,2-dioxolane $\mathbf{5 5}$ (Scheme 7). After separation of the diastereomeric mixture isomer $\mathbf{5 5 \mathbf { b }}$ was used for further transformations.

Enantiomerically pure $\mathbf{5 5 b}$ was reduced by $\mathrm{LiBH}_{4}$ to alcohol $\mathbf{5 6}$, which was transformed to vinylether $\mathbf{5 7}$ by subsequent PCC oxidation and Wittig olefination. Oxidation of $\mathbf{5 7}$ to methyl ester $\mathbf{5 8}$, reductive ozonolysis of 58, and Wittig olefination gave predominantly the Z-isomer of vinyl iodide $\mathbf{5 9}$. The Negishi coupling of $\mathbf{5 9}$ with the halogen derivative led to the desired product $\mathbf{6 0}$. Desilylation of $\mathbf{6 0}$ followed by reduction of $\mathbf{6 1}$ resulted in saturated alcohol $\mathbf{6 2}$. The oxidation of $\mathbf{6 2}$ led to an aldehyde, the Wittig olefination of which provided the precursor 63 as a mixture of isomers. The product of photoinduced isomerization of this mixture was the trans-isomer 64 . The target epiplakinic acid F (8) was obtained by alkaline hydrolysis of ester 64 (Scheme 8). 

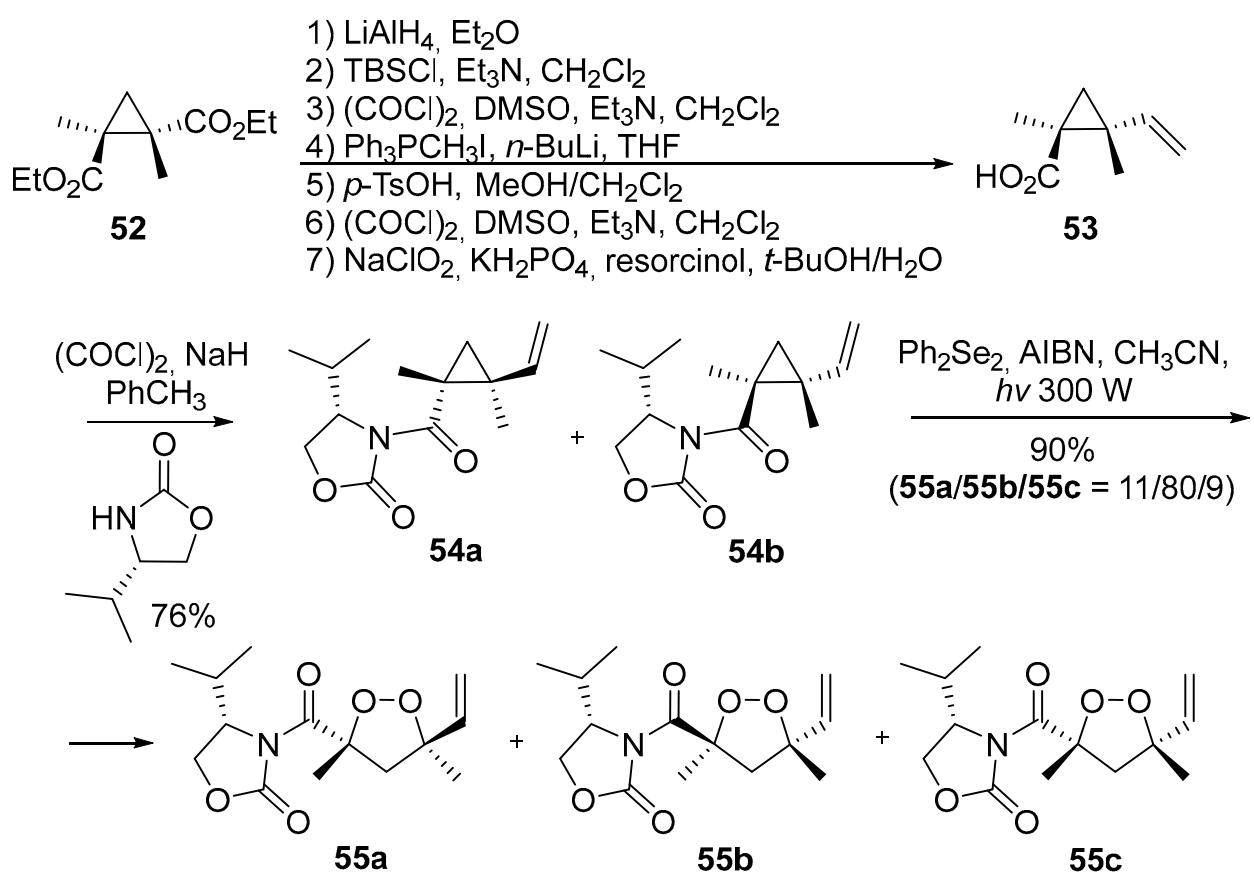

Scheme 7. Construction of 1,2-dioxolane fragment for epiplakinic acid F (8).<smiles>C=C[C@]1(C)C[C@](C)(C(=O)N2C(=O)OC[C@H]2C(C)C)OO1</smiles>

$55 b$<smiles>C=C[C@]1(C)C[C@@](C)(CO)OO1</smiles>

1) $\mathrm{PCC}, \mathrm{CH}_{2} \mathrm{Cl}_{2}$

2) NaHMDS,

$\mathrm{MeOCH}_{2} \mathrm{PPh}_{3} \mathrm{Cl}$<smiles>[B]C1(C=C)C[C@](C)(/C=C/OC)OO1</smiles>

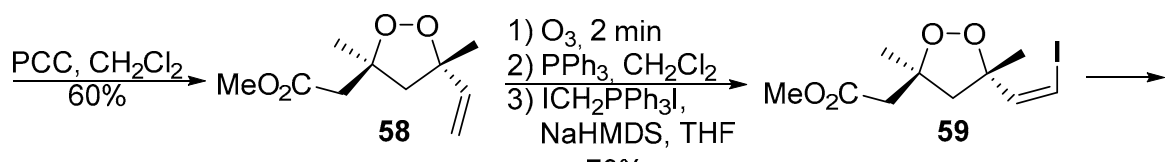

1) $\mathrm{ZnCl}_{2}, \mathrm{TBSO}_{2} \mathrm{X}_{6}$,

$t$-BuLi, $\mathrm{Et}_{2} \mathrm{O} / \mathrm{THF}$

2) $\left[\mathrm{Pd}\left(\mathrm{PPh}_{3}\right)_{4}\right], \mathrm{THF} \quad \mathrm{MeO}_{2} \mathrm{C}$

$77 \%$

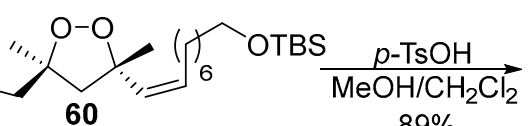

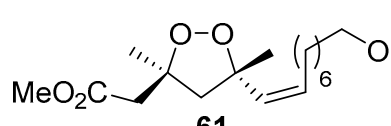

61 $\begin{aligned} & \mathrm{KO}_{2} \mathrm{CN}=\mathrm{NCO}_{2} \mathrm{~K} \\ & \mathrm{AcOH}, \mathrm{CH}_{2} \mathrm{Cl}_{2}\end{aligned} \underset{85 \%}{\stackrel{\mathrm{AeO}}{\longrightarrow}} \mathrm{MeO}_{2} \mathrm{C}$

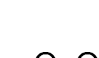

Dess-Martin periodinane $\mathrm{CH}_{2} \mathrm{Cl}_{2}$

62

$\mathrm{I}_{2}, \mathrm{CH}_{2} \mathrm{Cl}_{2}$

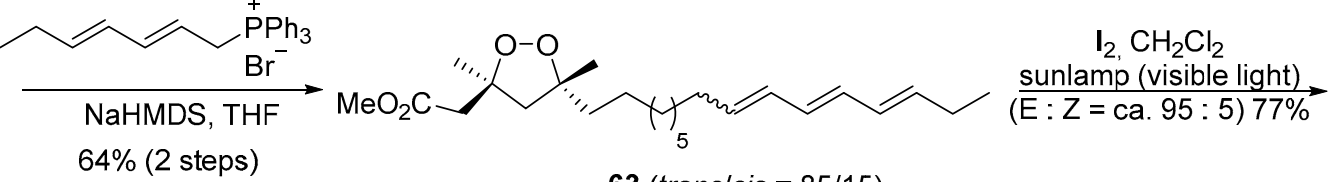

$63($ trans/cis $=85 / 15)$

$\mathrm{LiOH}$

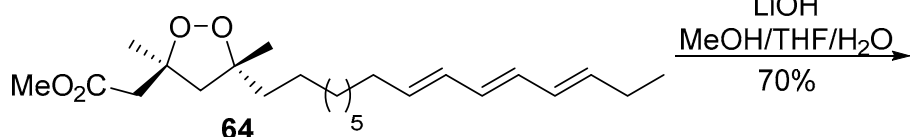

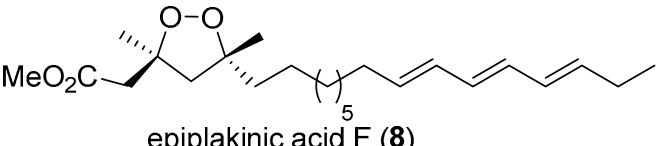

Scheme 8. Asymmetric synthesis of epiplakinic acid F (8). 
The method of the preparation of andavadoic acid (76), a natural compound isolated from the sponges of Plaxortis aff simplex, based on the Isayama-Mukaiyama reaction and subsequent cyclization was known [66]. The starting substrate was epichlorohydrin (65), which was converted to epoxide 66 by a subsequent the organomagnesium compound addition and cyclization with the help of alkaline. The regioselective opening of the epoxide cycle of 66 by the lithium salt of ethyl propiolate in the presence of $\mathrm{BF}_{3}$ resulted in the secondary alcohol 67 in almost quantitative yield. Alcohol 67 was converted into lactone 68 by reaction with $\mathrm{Me}_{2} \mathrm{CuLi}$, followed by acidification. Oxidation of lactone 68 to 69 , subsequent ring opening, oxidation of hydroxyl to the carbonyl group, and methylation resulted in epoxy ketone 70, which was then converted to epoxy alkene 71. Isayama-Mukaiyama peroxidation, the base-catalyzed cyclization of peroxide $\mathbf{7 2}$, leading to a mixture of diastereomeric 1,2-dioxolanes 73/73a followed by separation and thioacylation resulted in a peroxy thioester 74 which was converted into andavadoic acid (76) by subsequent reduction and hydrolysis of ester 75 (Scheme 9).

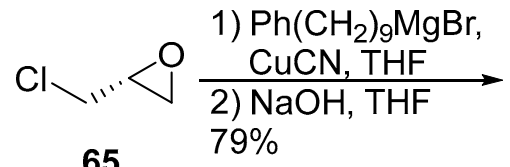
65<smiles>CCOC(=O)C#CCC(O)[Y20](c1ccccc1)c1ccccc1</smiles>
67

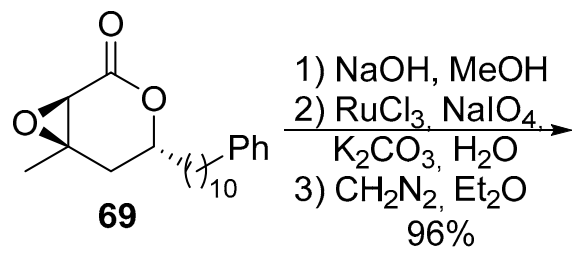

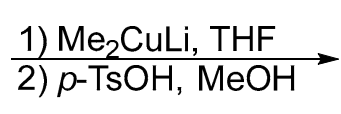
$84 \%$<smiles>[Te]=[Y8]([PbH])C1CO1</smiles>
66
1) ethyl acetylenecarboxylate

$$
\text { 2) } \mathrm{BF}_{3} \cdot \mathrm{Et}_{2} \mathrm{O}, 66
$$

$98 \%$

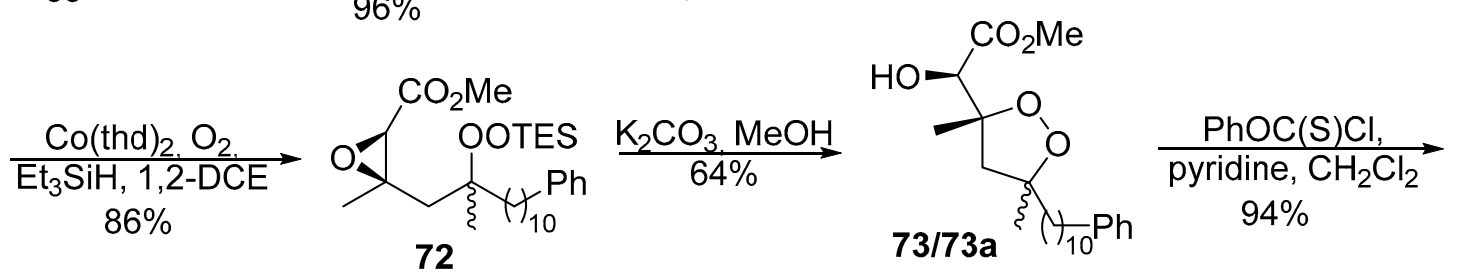

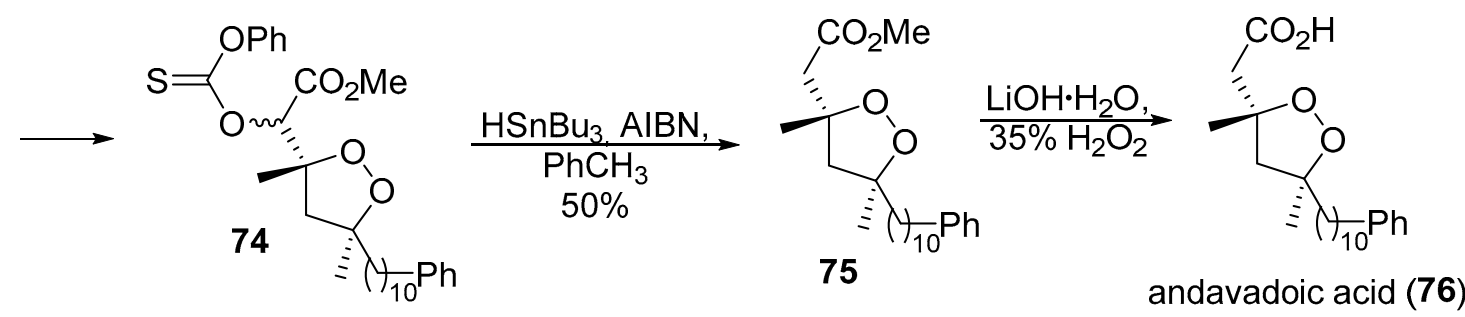

Scheme 9. Synthesis of andavadoic acid (76).

The symbiont of beetle of the southern pine (Dendroctonus frontalis), actinomycetous bacterium produces mycangimycin peroxide (77) with pronounced fungicidal activity (Scheme 10) [67]. Mycangimycin effectively inhibits growth of Candida albicans wild type, C. albicans ATCC10231, amphotericin-resistant strain C. albicans ATCC 200955, Saccharomyces cerevisiae and Ophiostoma minus [68]. 
<smiles>C=C/C=C/C=C\C=C\C=C\C=C/C=C\C[C@H]1C[C@@H](CC(=O)O)OO1</smiles>

C. albicans wild type

C. albicans ATCC 10231

C. albicans ATCC 2009550.4

S. cerevisiae

Penicillium $s p$.

O. minus

Entomocorticium $s p$.
$\operatorname{MIC}(\mu \mathrm{g} / \mathrm{mL})$

0.2

0.4

6.2

1.2

Scheme 10. Natural peroxide mycangimycin and its fungicidal activity.

Two saturated analogs of mycangimycin were synthesized from alkene $\mathbf{7 8}$ and ester $\mathbf{7 9}$ (Scheme 11) [69]. The Kulinkovich reaction of $\mathbf{7 8}$ with $\mathbf{7 9}$ resulted in cyclopropane 80, which formed 1,2-dioxolane 81 by a cobalt-catalyzed cleavage in the presence of oxygen. TfOH-catalyzed reduction of the alcohol 81 by silane led to 3,5-disubstituted 1,2-dioxolane 82. The result of desilylation and oxidation of the obtained alcohol $\mathbf{8 3}$ is the first saturated analog of mycangimycin, acid $\mathbf{8 4}$, which can be converted into ester 85 .

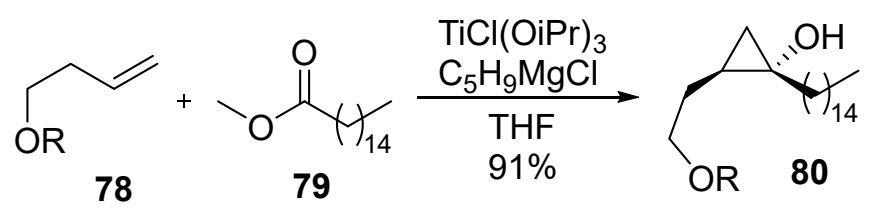

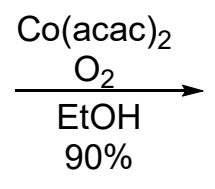<smiles>[R]OCCC1CC(O)(O)OO1</smiles>

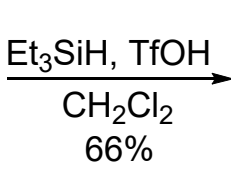<smiles>[R20]CCC1CC([AlH]C)OO1</smiles>

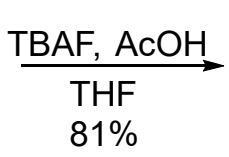<smiles>OCCC1CC([18OH])OO1</smiles>

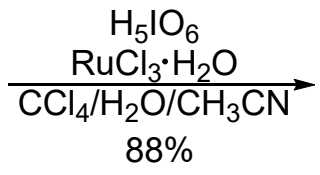<smiles>CC(C)(C)C=CC1CC(CC(=O)O)OO1</smiles><smiles>COC(=O)CC1CC([14CH3])OO1</smiles>

$\mathrm{R}=\mathrm{TBDPS}$

Scheme 11. The synthesis of saturated analogs of mycangimycin 84 and 85 .

The diterpenoid peroxide 86 , which has a weak fungicidal activity against $C$. albicans, was isolated from the liverwort Jungermannia atrobrunnea (Scheme 12) [70]. Dinardokanshone B (87), sesquiterpene peroxide, isolated from the roots and rhizomes of Nardostachys chinensis Batal. (Valerianaceae) showed significant enhancement effects on SERT activity (Scheme 12) [71].

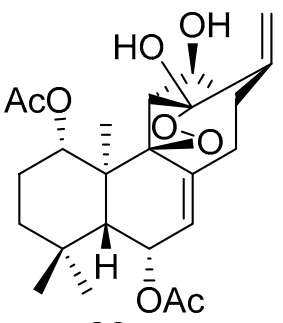

86

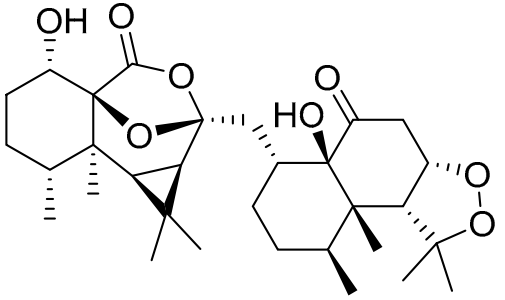

87

C. albicans MIC $=128 \mu \mathrm{g} / \mathrm{mL}$

SERT enhancement activity

Scheme 12. Terpene peroxides 86 and 87. 
Synthetic 1,2-dioxolanes 88 showed high in vitro activity against helminths Schistosoma mansoni (Scheme 13) [72].<smiles>[R]C1([R])CC([R])([R])OO1</smiles>

88

$$
\begin{gathered}
\mathrm{R}_{1}, \mathrm{R}_{2}=\mathrm{Me}, \mathrm{Bu},-\left(\mathrm{CH}_{2}\right)_{5^{-}} \\
\mathrm{R}_{3}=\mathrm{Me}, \mathrm{CH}_{2} \mathrm{CH}_{2} \mathrm{Ph} \\
\mathrm{R}=\mathrm{CH}_{2} \mathrm{CH}_{2} \mathrm{Ph}, \mathrm{Bn}
\end{gathered}
$$

NTS S. mansoni $\mathrm{IC}_{50}<20 \mu \mathrm{M}$

Scheme 13. 1,2-Dioxolanes 88 exhibiting high activity against schistosomiasis.

5,5-Dimethyl 1,2-dioxolanes 88a were prepared by peroxidation of mesityl oxide (89) in the basic medium, followed by alkylation of the free hydroxyl group of 3-hydroxy-1,2-dioxolanes 90 (Scheme 14) [73]. Synthesis of cyclohexyl derivatives $\mathbf{8 8 b}$ started from oxidation of alcohol 92 to an unsaturated ketone $\mathbf{9 3}$, followed by Isayama-Mukaiyama peroxidation with formation of 1,2-dioxolane 94 . Further protection of hydroxyl group resulted in derivatives $\mathbf{8 8 b}$ (Scheme 14) [73].
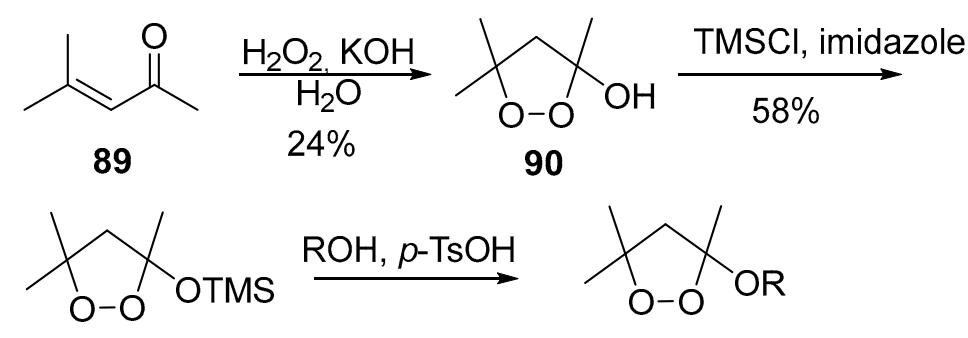

91<smiles>[R]C1(C)CC(C)(C)OO1</smiles>

$88 a$<smiles>[R]C(O)CC1=CCCCC1</smiles>

92

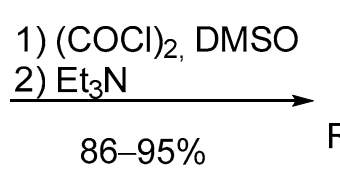
1) $(\mathrm{COCl})_{2}, \mathrm{DMSO}$ $86-95 \%$<smiles>[R3]C(=O)CC1=CCCCC1</smiles>

93
$\mathrm{Co}(\mathrm{acac})_{2}$, $\underset{5 t_{3} \mathrm{SiH}, \mathrm{O}_{2}}{\longrightarrow}$

$52-58 \%$

$\mathrm{R}_{3}=\mathrm{Me}, \mathrm{Bn}$<smiles>[R]C1(O)CC2(CCCCC2)OO1</smiles>

94

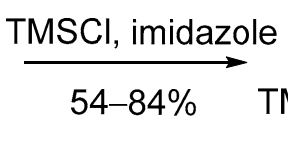

$54-84 \%$

Scheme 14. Synthesis of anthelmintic 1,2-dioxolanes 88 .<smiles>[R]C1([R])CC2(CCCCC2)OO1</smiles>

88b

The series of tricyclic monoperoxides 97 with 1,2-dioxolane moiety showed a high anti-schistosomal activity. The maximum activity was observed for compound 97a, which revealed high worm burden reductions by $82.8 \%$ in S. mansoni mouse model (Scheme 15) [74]. Peroxides 97 can be obtained from $\beta$, $\delta$-triketones 96 and hydrogen peroxide with use of either sulfuric acid [75], or boron trifluoride [76] as catalyst and co-solvent (Scheme 15). 
<smiles>[R]C(=O)C([R])(CCC(C)=O)C(C)=O</smiles><smiles>O=S(=O)(O)OCCCCCO</smiles>

or $\mathrm{H}_{2} \mathrm{O}_{2}, \mathrm{BF}_{3} \cdot \mathrm{Et}_{2} \mathrm{O}, \mathrm{Et}_{2} \mathrm{O}$ 39-91\%

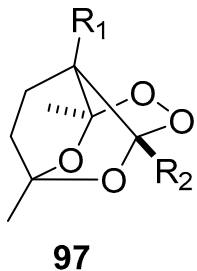

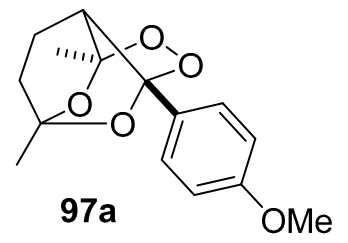

in vitro:

S. mansoni adult $\mathrm{IC}_{50}=11.7 \mu \mathrm{M}$

S. mansoni NTS $\mathrm{IC}_{50}=14.4 \mu \mathrm{M}$

in vivo:

worm burden reduction $82.8 \%$

Scheme 15. Synthesis of tricyclic monoperoxides 97 with high anti-schistosomal activity.

\section{1,2,4-Trioxolanes (Ozonides)}

Various tetrasubstituted 1,2,4-trioxolanes (ozonides) have become the breakthrough in the field of biologically active synthetic peroxides. Nowadays ozonides are considered as the most promising candidates in the treatment of helminth diseases (Scheme 16). The 100\% worm burden reductions were observed with a single oral dose of $1000 \mathrm{mg} / \mathrm{kg}$ OZ78 (98) in Echinostoma caproni-infected mice. A single dose of $100 \mathrm{mg} / \mathrm{kg}$ OZ78 (98) resulted in 100\% worm burden reductions against juvenile and adult Fasciola hepatica-mouse model [77]. Single oral doses of $100 \mathrm{mg} / \mathrm{kg}$ OZ78 (98) is efficient against adult triclabendazole-resistant $F$. hepatica-infected rats [78]. Later, the efficacy of 1,2,4-trioxolane OZ78 (98) against an experimental infection with Fasciola hepatica in sheep was confirmed $[79,80]$. It was found that the spiroadamantane fragment and the carboxyl group in the OZ78 (98) are necessary for activity against $F$. hepatica [81].

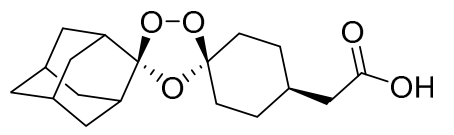

OZ78 (98)

in vivo: $100 \%$ worm burden reduction in mice Fasciola hepatica (adult and juvenile) $100 \mathrm{mg} / \mathrm{kg}$ Echinostoma caproni $1000 \mathrm{mg} / \mathrm{kg}$

in vivo: $200 \mathrm{mg} / \mathrm{kg}$

- juvenile Schistosoma mansoni

$82 \%$ worm burden reduction in mice

- adult Schistosoma mansoni

$85 \%$ worm burden reduction in hamsters

- adult Schistosoma japonicum

$94 \%$ worm burden reduction in hamsters

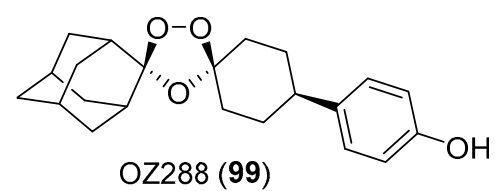

in vivo: $200 \mathrm{mg} / \mathrm{kg}$

- juvenile Schistosoma mansoni $95 \%$ worm burden reduction in mice - adult Schistosoma mansoni $52 \%$ worm burden reduction in mice

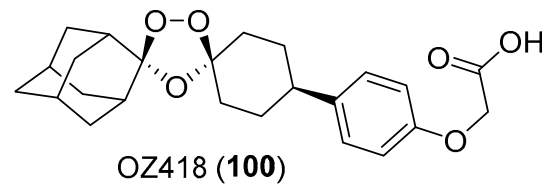

in vivo: $200 \mathrm{mg} / \mathrm{kg}$

- juvenile Schistosoma mansoni $100 \%$ worm burden reduction in mice

- adult Schistosoma mansoni $(400 \mathrm{mg} / \mathrm{kg}$ )

$80 \%$ worm burden reduction in mice

- adult Schistosoma haematobium $(400 \mathrm{mg} / \mathrm{kg})$

$86 \%$ worm burden reduction in mice

Scheme 16. Tetrasubstituted synthetic ozonides with the highest anthelmintic activity.

The ozonides OZ78 (98) and OZ288 (99) showed low toxicity and high efficiency against helminth cultures Schistosoma mansoni and S. japonicum harboured in mice and hamsters with a single oral dose of $200 \mathrm{mg} / \mathrm{kg}[82,83]$. Antichistosomal activity of OZ78 (98) against S. japonicum was confirmed in 
experiments in mice and rabbits [84]. Later, the promising ozonide OZ418 (100) with high activity against both helminths of $S$. mansoni and S. haematobium was discovered [85].

Synthesis of tetrasubstituted unsymmetrical ozonides was discovered by Griesbaum and colleagues in 1995 (Scheme 17, top) [86,87]. Later this method was used for the diastereoselective synthesis of tetrasubstituted ozonides 103. Peroxides 103 were prepared by ozonolysis of 2-adamantanone O-methyl oxime (101) in the presence of substituted cyclohexanones 102 (Scheme 17, bottom) [88,89]. 1,2,4-Trioxolane ring in compounds $\mathbf{1 0 3}$ is resistant to the action of a wide range of reagents, which allows to proceed a variety of modifications of the cyclohexane substituent [88].

Griesbaum co-ozonolysis

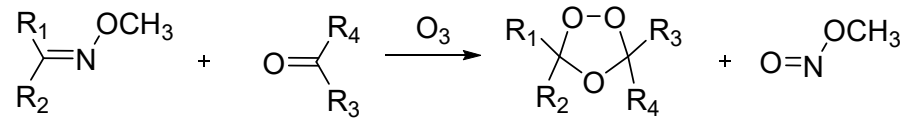

Synthesis of tetrasubstituted unsymmetrical ozonides

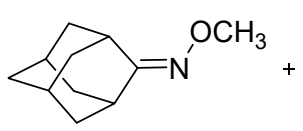

101

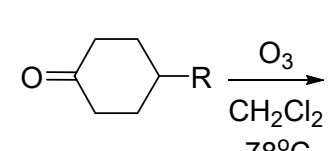

102 $-78^{\circ} \mathrm{C}$

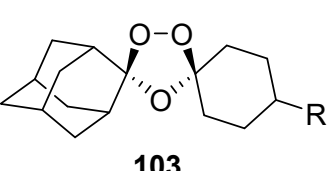

reactions in which the peroxide ring remains intact

Scheme 17. Synthesis of tetrasubstituted unsymmetrical ozonides.

\section{1,2-Dioxanes}

A number of compounds containing 1,2-dioxane fragment isolated from the Plakinidae sponges showed high fungicidal and anti-trypanosomal activity. Plakinic acid B (104) exhibited good fungicidal activity against Saccharomyces cerevisiae and Penicillium atrovenetum (Scheme 18) [56]. The acid 105 in vitro inhibits the growth of fungi Aspergillus fumigatus with $\mathrm{IC}_{90}=5.6 \mu \mathrm{g} / \mathrm{mL}$ [58]. Compounds 106 and 107 were weakly active against Staphylococcus aureus [90]. 11,12-Didehydro-13-oxo-plakortide Q (108) was more active against Trypanosoma brucei [91]. Plakortide F acid (PFA) (109) showed high activity against Candida albicans, Cryptococcus neoformans and A. fumigatus [21]. Plakortides 110 and 111 also demonstrated high activity against a number of fungi [92]. Significant fungicidal activity of mixture of peroxyketal acids isolated from sea sponges was also reported [93].

A series of peroxyterpenes was isolated from the sponges Diacarnus bismarckensis, the most active of which, (+)-muqubilone B (112) and sigmosceptrellin B (113) showed high activity against Trypanosoma brucei [94]. (+)-Muqubilone B (112) and muqubilin (114) (isolated from the sponges Prianos [95]) were in vitro effective against herpes virus (HSV-1), muqubilin (114) and (-)-sigmosceptrellin B (113) exhibited in vitro activity against Toxoplasma gondii (Scheme 19) [96]. Muqubilin (114) possesses herbicidal activity against tobacco Nicotiana tabacum [97], as well as epimuqubilin (115) showed NO inhibitory activity [98]. Mycaperoxide B (116) displays high antiviral activity against vesicular stomatitis virus and herpes simplex virus type-1 (HCV-1) [99].

Several synthetic approaches to plakinic acids and their derivatives containing 1,2-dioxane ring were described. Natural 6-epiplakortolide E (127) was firstly synthesized from available 1-bromo-10-phenyldecane (117) in 10 steps by Diels-Alder reaction with singlet oxygen followed by iodolactonization (Scheme 20) [100]. In the first stage, the addition of the organomagnesium reagent to the unsaturated ketone resulted in enone 118, which was converted to a tertiary alcohol 119. Hydroboration of 119 led to diol 120, protection of hydroxyl group of which provide silyl ether 121. Diels-Alder reaction of diene $\mathbf{1 2 2}$ prepared by dehydration of $\mathbf{1 2 1}$ with singlet oxygen resulted in diastereomeric 1,2-dioxanes 123a and 123b. Deprotected diastereomer 124 was oxidized to acid 125, subsequent iodolactonization of this acid gave bicycle 126. Desirable 6-epiplakortolide E (127) was formed as result of radical reduction of iodine-containing bicycle 126. It was noted that related plakortolide G (128) is active against the protozoa Toxoplasma gondii [101]. 
<smiles>CC(/C=C/c1ccccc1)C/C=C/C(C)C[C@]1(C)C[C@@H](C)[C@@H](CC(=O)O)OO1</smiles>

plakinic acid B (104)

S. cerevisiae $20 \mathrm{~mm}$ zone of inhibition ( $100 \mu \mathrm{g} / \mathrm{disk})$ P. atrouenetum $18 \mathrm{~mm}$ zone of inhibition $(100 \mu \mathrm{g} / \mathrm{disk})$<smiles>CC(CCCCCC/C=C/c1ccccc1)C[C@@H]1C[C@@H](C)[C@@H](O)[C@](C)(C(=O)O)OO1</smiles><smiles>CCC(/C=C/C(C)=O)CC(C)C[C@]1(CC)CC(CC)C(CC(=O)O)OO1</smiles>

11,12-didehydro-13-oxo-plakortide $Q$ (108) T. brucei $\mathrm{IC}_{50}=49 \mathrm{nM}$<smiles>CCCCCCC1(CC)C[C@H](CC)[C@@H](CC(=O)O)OO1</smiles>

$\mathrm{MIC}_{90}(\mu \mathrm{M}) n=1110 n=2111$

Candida albicans $\quad 27 \quad 22$

Cryptococcus gattii $36 \quad 9.6$

Cryptococcus grubii $26 \quad 6.0$

$\begin{array}{lll}\text { Candida krusei } & 10 & 4.3\end{array}$

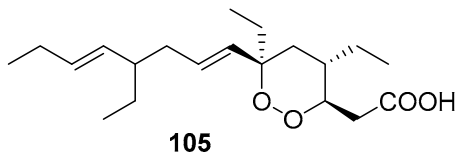

A. fumigatus $\mathrm{IC}_{90}=5.6 \mu \mathrm{g} / \mathrm{mL}$<smiles>CC(CCCCCCCc1ccccc1)C[C@H]1CC(C)[C@](C)(O)OO1</smiles>

S. aureus $\mathrm{MIC}=64 \mu \mathrm{g} / \mathrm{mL}$<smiles>CC/C=C/C(CC)CCCC1(CC)C[C@H](CC)[C@@H](CC(=O)O)OO1</smiles>

plakortide $\mathrm{F}$ acid (109)

C. albicans $\mathrm{IC}_{50}=0.03 \mu \mathrm{g} / \mathrm{mL}$

Cryptococcus neoformans $\mathrm{IC}_{50}=0.75 \mu \mathrm{g} / \mathrm{mL}$

A. fumigatus $\mathrm{IC}_{50}=2.00 \mu \mathrm{g} / \mathrm{mL}$

Scheme 18. 1,2-Dioxanes isolated from the sponges Plakinidae; their antifungal, antibacterial and anti-trypanosomal activity is also shown.<smiles>CC(=O)CCCC(C)(C)C(=O)CC/C(C)=C/CC[C@]1(C)CC[C@H](C(C)C(=O)O)OO1</smiles>

muqubilone $B(112)$

T. brucei $\mathrm{IC}_{50}=2 \mu \mathrm{g} / \mathrm{mL}$ herpes simplex type 1 (HSV-1) $\mathrm{ED}_{50}=30 \mu \mathrm{g} / \mathrm{mL}$<smiles>CC1=C(CC/C(C)=C/CC[C@]2(C)CC[C@H]([C@@H](C)C(=O)O)OO2)C(C)(C)CCC1</smiles>

herpes simplex type $1(\mathrm{HSV}-1) \mathrm{ED}_{50}=7.5 \mu \mathrm{g} / \mathrm{mL}$ Toxoplasma gondii $>90 \%$ inhibition $0.1 \mu \mathrm{M}$ гербицидный эфрфрект $66 \%$ Nicotiana tabacum $6.4 \mu \mathrm{M}$

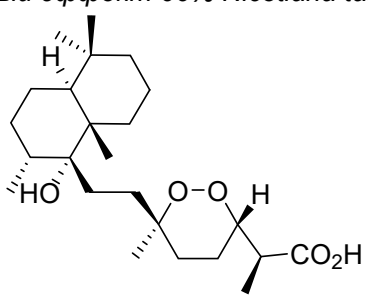

mycaperoxide $B$ (116)

herpes simplex type 1 (HSV-1) $\mathrm{IC}_{50}=0.25-1.0 \mu \mathrm{g} / \mathrm{mL}$ vesicular stomatitis virus $\mathrm{IC}_{50}=0.25-1.0 \mu \mathrm{g} / \mathrm{mL}$

Scheme 19. Muqubilin (114) and related natural peroxides.

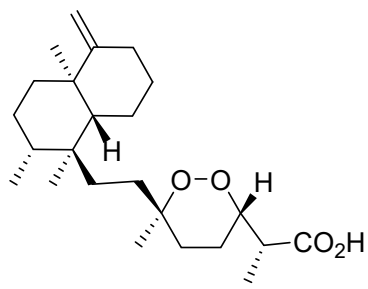

sigmosceptrellin B (113)

T. brucei $\mathrm{IC}_{50}=0.2 \mu \mathrm{g} / \mathrm{mL}$

Toxoplasma gondii $>90 \%$ inhibition $0.1 \mu \mathrm{M}$

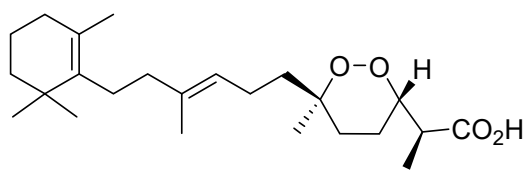

epimuqubilin A (115)

$\mathrm{NO}$ inhibitory activity $\mathrm{IC}_{50}=7.4 \mu \mathrm{M}$ 

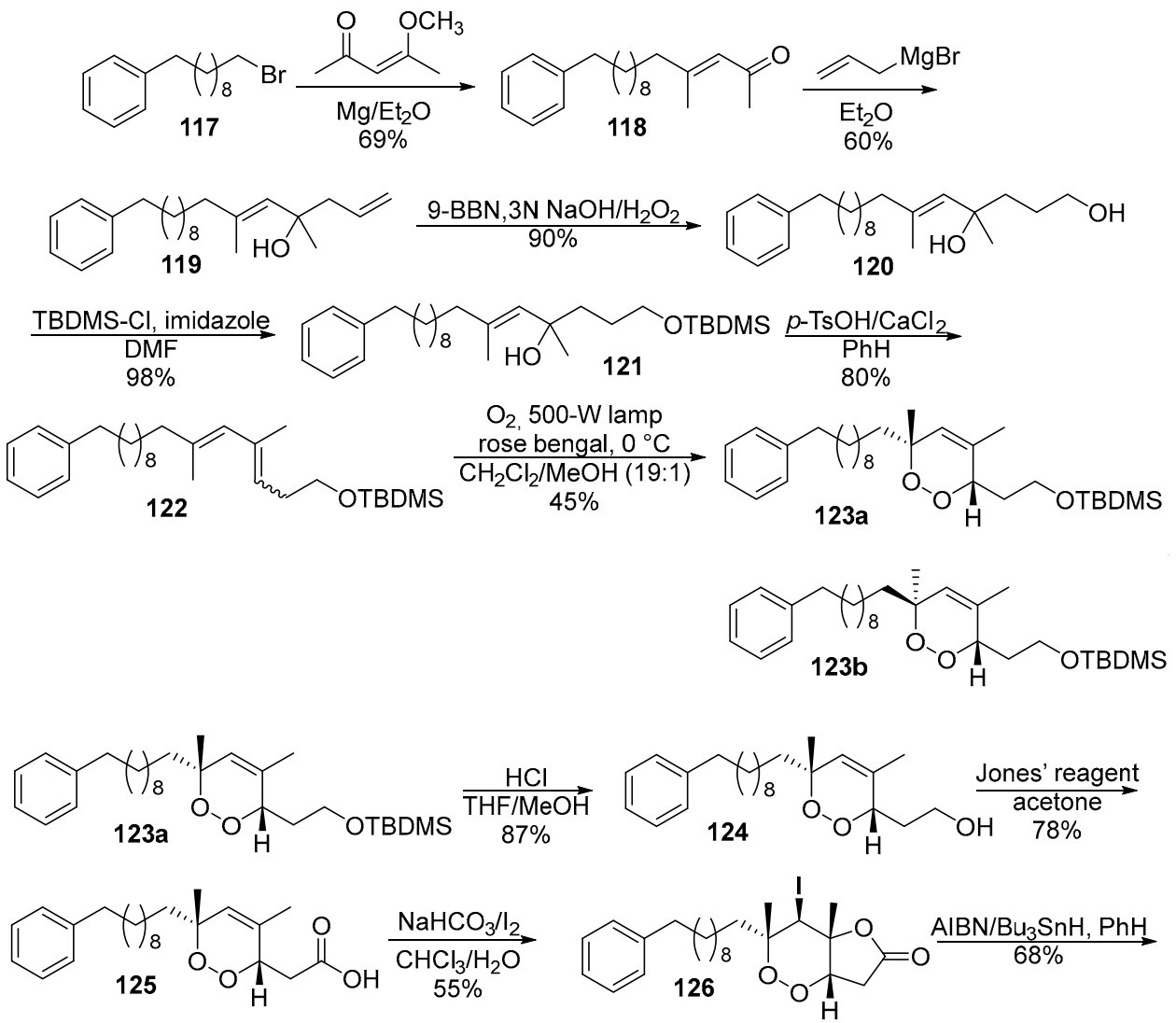<smiles>CC(Cc1ccccc1)CC1(C)C[C@](C)(CCc2ccccc2)OO[C@H]1CC(=O)O</smiles>

6-epiplakortolide $\mathrm{E}$ (127)

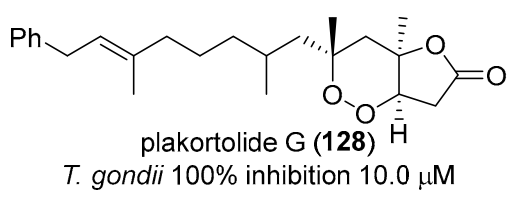

T. gondii $100 \%$ inhibition $10.0 \mu \mathrm{M}$

Scheme 20. Synthesis of 6-epiplakortolide E (127).

Asymmetric synthesis of alkoxy-1,2-dioxane 136 related to plakortolides was realized in 8 steps from carbonyl compounds 129 and 130 (Scheme 21) [102]. Enantioselective aldol reaction in first step resulted in aldol $\mathbf{1 3 1}$ which was converted into protected diol $\mathbf{1 3 2}$ in three steps. Diastereomeric 1,2-dioxanes 133a and 133b were formed by selective ozonolysis of double bond of 132. Hydrozirconation of 133a with following treatment by iodine led to the formation of vinyl iodide 134, followed cross-coupling of one resulted in 1,2-dioxane 135. Deprotection of 135 provided desirable peroxide 136.

Natural endoperoxide 9,10-dihydroplakortin (148) and diastereomer 149 were synthesized through Evans' chiral auxiliary chemistry (Scheme 22) [103]. Alkylation of oxazolidinone 137 and subsequent reduction of $\mathbf{1 3 8}$ led to alcohol 139, which was transformed into acrylic ester $\mathbf{1 4 0}$ (predominantly in E-configuration) by oxidation and Horner-Wadsworth-Emmons olefination. The ester 140 was reduced into corresponding alcohol, which was converted into iodide 141, alkylation of oxazolidinone by which resulted in derivative 142. The cleavage and olefination of 142 provided the ester 143. The reduction of $\mathbf{1 4 3}$ furnished alcohol $\mathbf{1 4 4}$ followed by Sharpless epoxidation and protection of primary hydroxy-group with formation of epoxide 145. Isayama-Mukaiyama peroxidation of epoxide 145 afforded mixture of diastereomeric 1,2-dioxanes 146 and 147 which were independently transformed into 9,10-dihydroplakortin (148) and 6-epi-dihydroplakortin (149). 

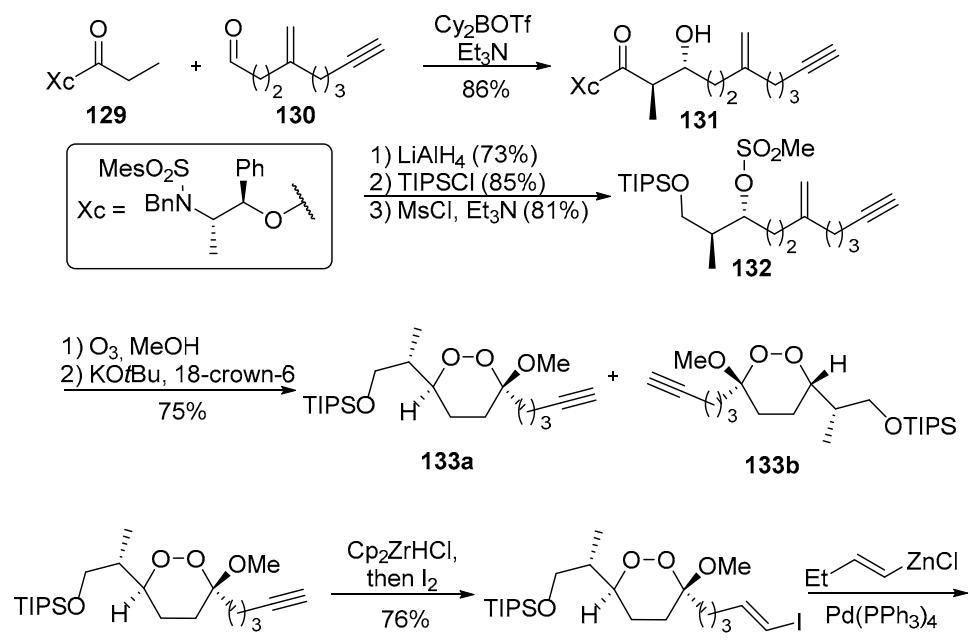

33a

134

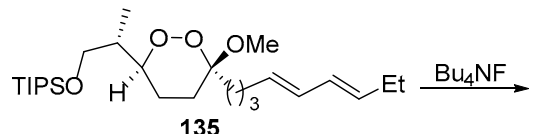

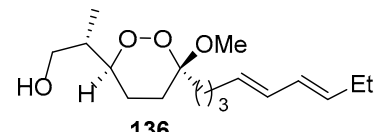

136

Scheme 21. Asymmetric synthesis of 1,2-dioxane 136.
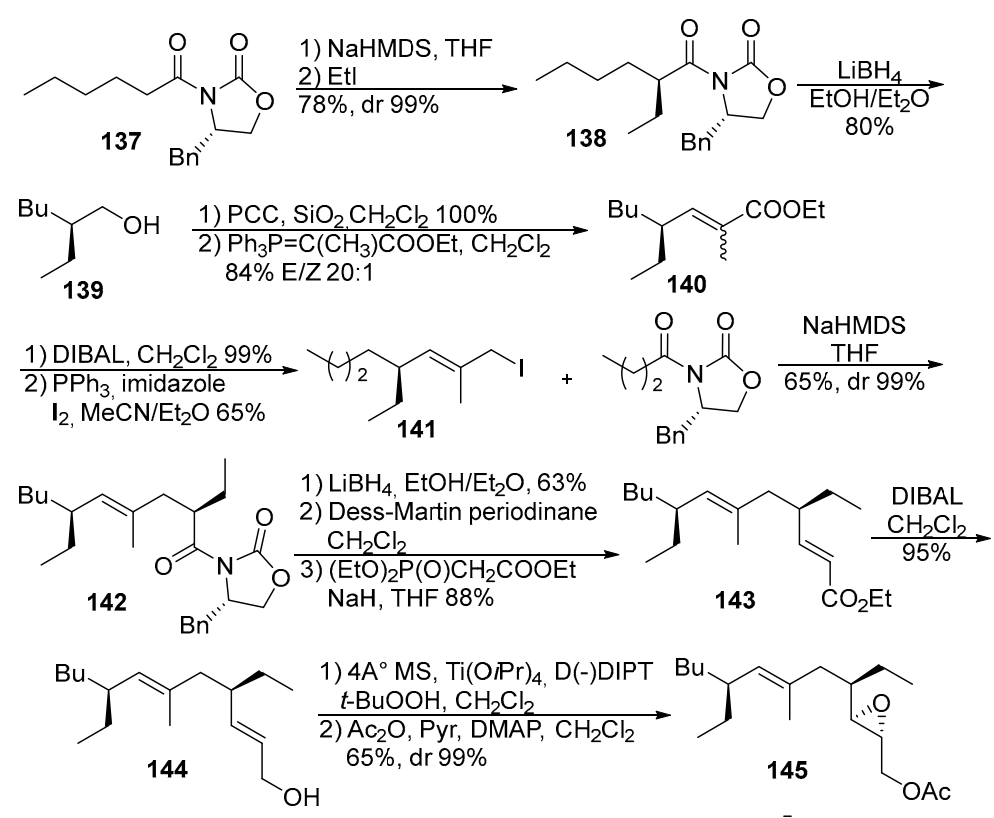

1) $\mathrm{Co}\left(\mathrm{thd}_{2}, \mathrm{Et}_{3} \mathrm{SiH}\right.$ $\mathrm{O}_{2}, 1,2-\mathrm{DCE}$

2) Amberlyst, $\mathrm{CH}_{2} \mathrm{Cl}_{2}$

3) $\mathrm{K}_{2} \mathrm{CO}_{3}, \mathrm{MeOH}$<smiles>CCC(CC(C)C)C[C@]1(C)C[C@H](CC)[C@H]([C@H](O)CO)OO1</smiles>

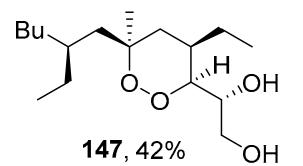

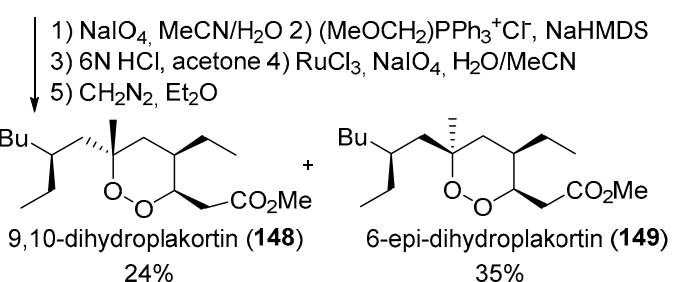

Scheme 22. Synthesis of natural endoperoxide 9,10-dihydroplakortin (148) and its diastereomer 149. 
In the synthesis of diastereomeric plakortolides 160 and 161, the key steps are construction of protected diol 155 from protected 2-methyl glycidol 154 and vinyl bromide 152, diastereoselective Mukaiyama addition of aldehyde 156 with formation of ester 157 and hydroperoxidation of alkene 158 with subsequent cyclization of $\mathbf{1 5 9}$ (Scheme 23) [104].
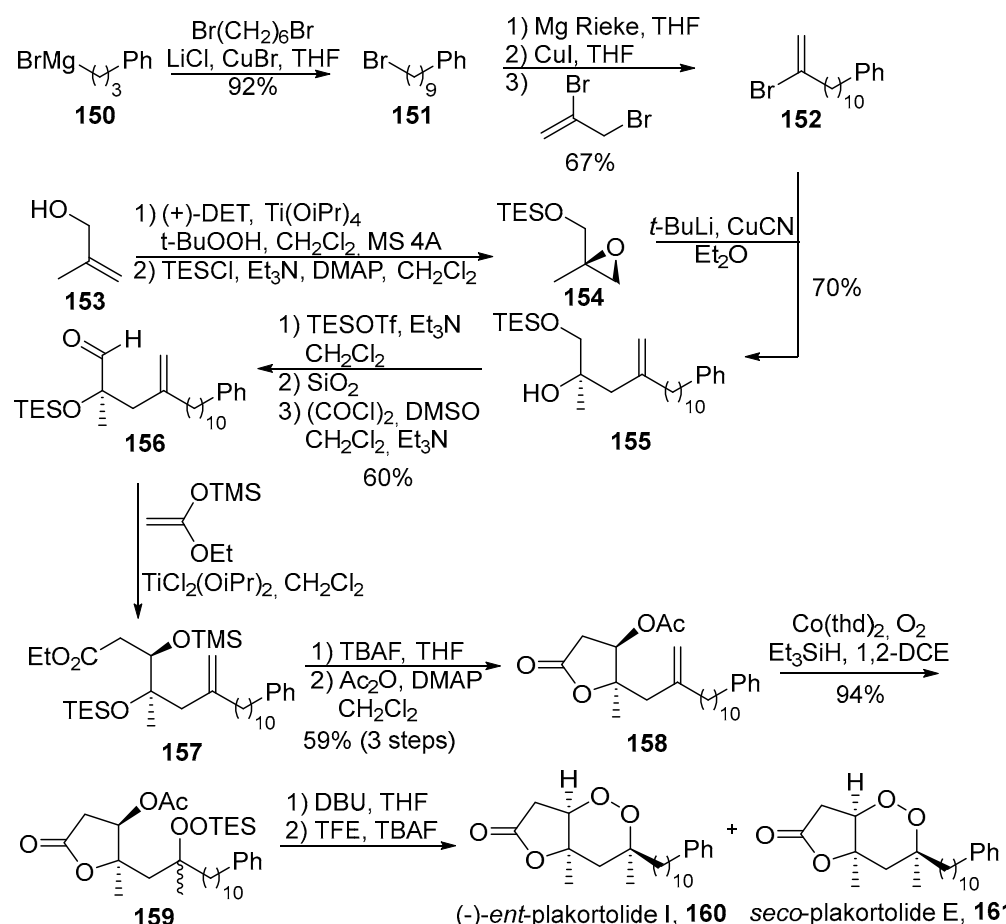

(-)-ent-plakortolide I, 160 seco-plakortolide E, 161

Scheme 23. Synthesis of diastereomeric plakortolides 160 and 161.

Synthesis of analogs of plakinic acids, 1,2-dioxanes 166 with a pronounced anti-trypanosomal activity was proposed from E-hexen-4-ol (162) (Scheme 24) [105]. Swern oxidation of alcohol 162 and subsequent Wittig-olefination led to ester 163. The reaction of unsaturated scaffold 163 with singlet oxygen and following cyclization provided 1,2-dioxane 164, which was hydrolyzed to acid $\mathbf{1 6 5}$. Derivatives 166 were prepared from ester 164 by consistent ozonolysis, reductive cleavage and Wittig reaction. Compounds 166 exhibited high activity against T. brucei brucei BF427.

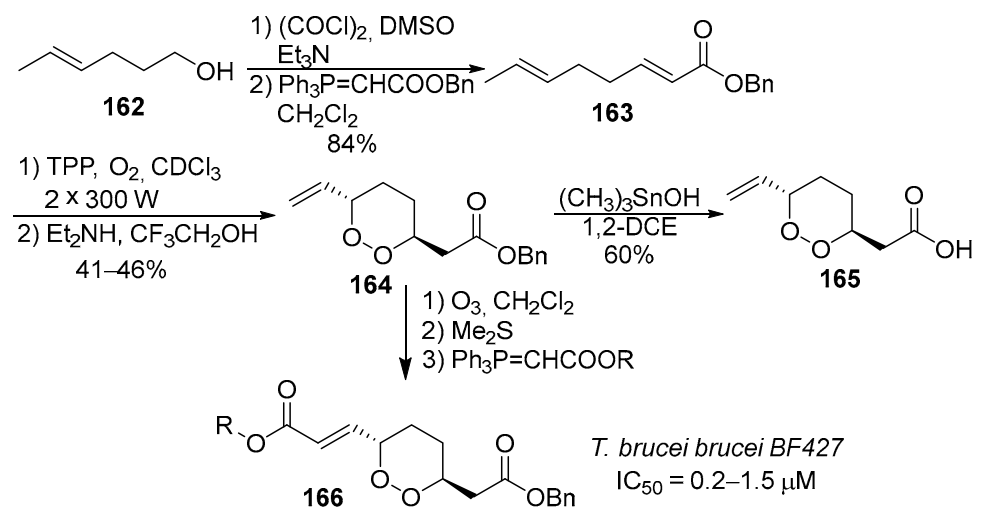

Scheme 24. Synthesis of 1,2-dioxanes 166 with high anti-trypanosomal activity.

Diastereomeric cyclic peroxides 171, one of which is the methyl ester of the mycaperoxide B (116), were prepared from protected hydroxyperoxide 167 (Scheme 25) [106]. In the first step, 
peroxide 167 was oxidized to aldehyde 168, which was converted into unsaturated ester 169 by Wittig reaction. Hydroperoxide 170 synthesized by deprotection of 169 was cyclized into 1,2-dioxane 171 and oxolane $\mathbf{1 7 2}$ by the action of triethylamine.
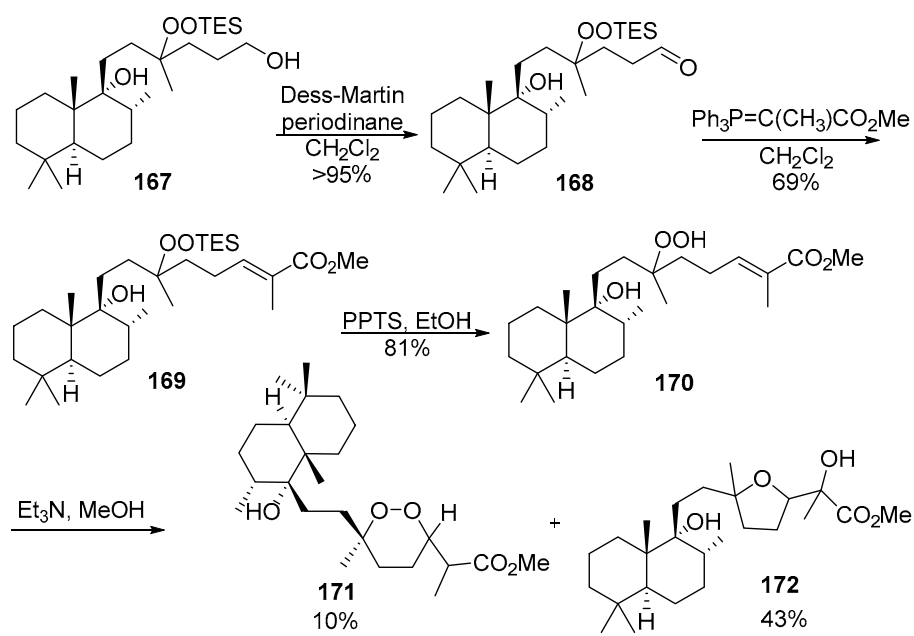

Scheme 25. Synthesis of diastereomeric peroxides 171.

\section{1,2-Dioxenes}

The plant Chenopodium ambrosioides is used for the production of essential chenopodium oil, which has been used as an anthelmintic agent for a long time [107,108]. The first isolation of the most active component-ascaridole (174), from the Chenopodium ambrosioides and the determination of its structure was dated to the beginning of the last century [109-112]. In the 1950s, the ascaridole (174) was completely characterized (Scheme 26) [113,114].

The first laboratory synthesis of ascaridole (174) was performed via photo-induced addition of singlet oxygen to terpene 173 by Schenck in 1944 (Scheme 26) [115]. Later, this reaction was realized in an industrial scale, because ascaridole was of great importance as an anthelmintic agent [116]. The method for the preparation of ascaridole using singlet oxygen generated in situ from sodium molybdate and hydrogen peroxide is known [117].

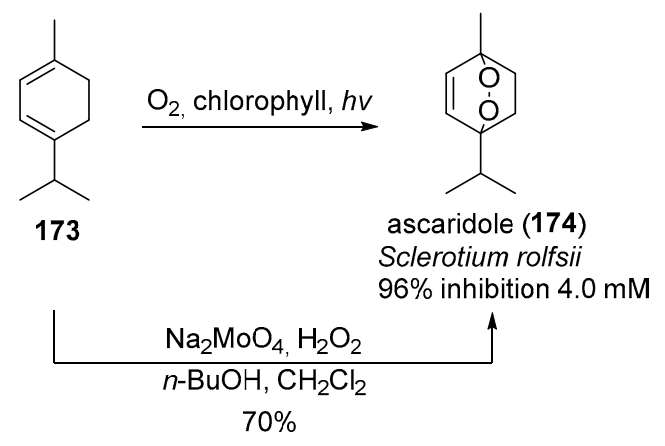

Scheme 26. Ascaridole synthesis (174).

It was shown that ascaridole (174) at concentration $4 \mathrm{mM}$ almost completely inhibits the growth of fungi Sclerotium rolfsii [118]. Presently, the side effects of ascaridole on the gastrointestinal tract have been described, and ascaridole is currently not used [119].

In 1990, Gunasekera with colleagues isolated 1,2-dioxenes 175 and 176 from sea sponge Plakortis angulospiculatus (Scheme 27) [120]. It was shown that these natural peroxides exhibit antifungal activity against Candida albicans (MIC $=1.6 \mu \mathrm{g} / \mathrm{mL}$ ). 


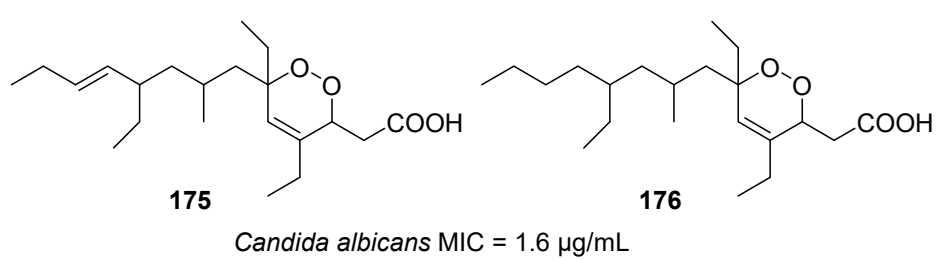

Scheme 27. Antifungal natural 1,2-dioxenes 175, 176.

The total synthesis of stereoisomeric 1,2-dioxenes $\mathbf{1 8 5}$ was performed in 18 steps with a total yield of $2.8 \%$ (Scheme 28) [121]. The treatment of hydroxy ester 177 with tert-butyldiphenylsilyl chloride followed by DIBAL reduction and replacement of hydroxyl by iodine provided iodide 178, which was converted into aldehyde $\mathbf{1 7 9}$ by subsequent asymmetric alkylation, reduction of prepared amide into alcohol and Swern oxidation. Alkene $\mathbf{1 8 0}$ was synthesized from sulfone derivative of aldehyde $\mathbf{1 7 9}$ to obtain mainly trans-isomer. Deprotection of $\mathbf{1 8 0}$, nucleophilic substitution of hydroxyl by iodine, subsequent substitution of iodine by cyano-group and reduction of cyano-group led to aldehyde $\mathbf{1 8 1}$ which was then transformed into alkyne 182 by $\mathrm{PPh}_{3} / \mathrm{CBr}_{4}$ treatment and $\mathrm{HBr}$ elimination. The synthesis of enone 183 was performed by addition of ethylcuprate followed by propionyl chloride to alkyne 182 . The diene $\mathbf{1 8 4}$ was prepared predominantly in trans-conformation by condensation of enone $\mathbf{1 8 3}$ with lithium salt of propargyl phosphonate with subsequent hydroboration. Ene reaction of diene $\mathbf{1 8 4}$ with singlet oxygen and methylation by diazomethane resulted in 1,2-dioxenes 185a and 185b.
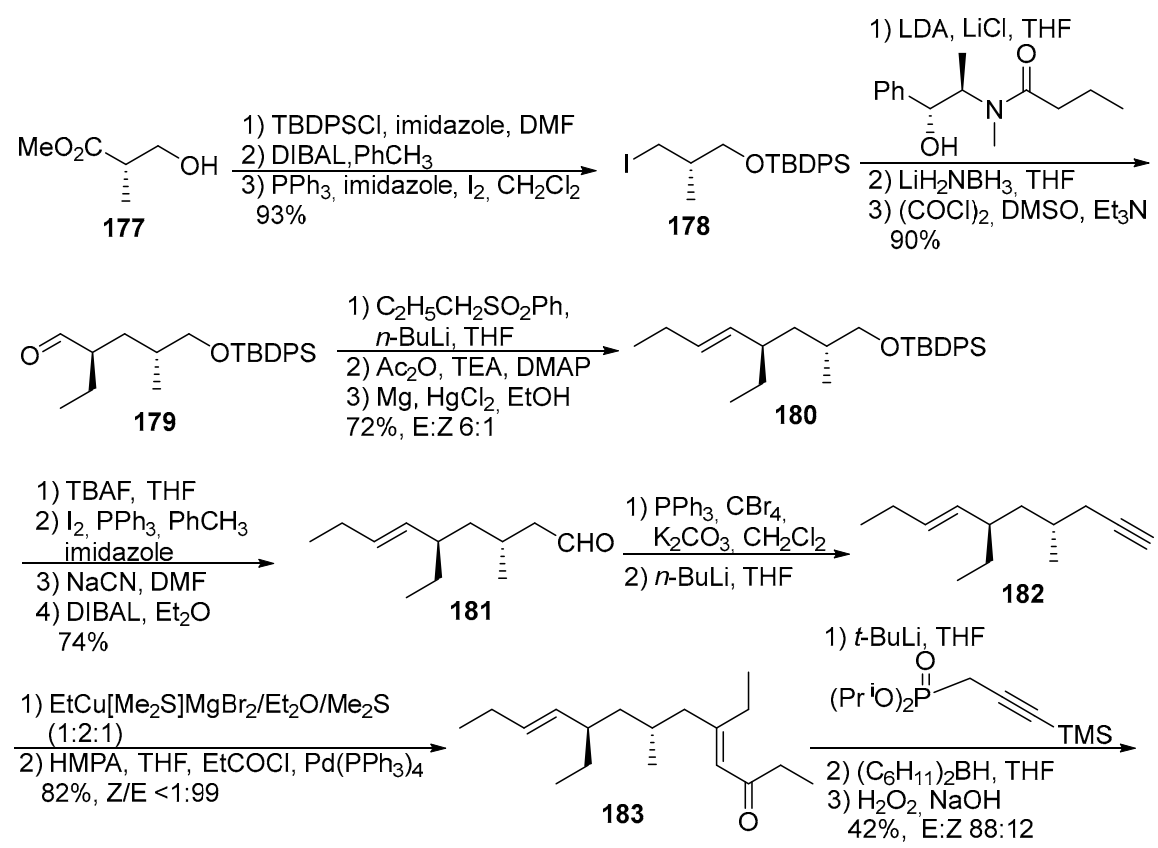

1) $\mathrm{EtCu}\left[\mathrm{Me}_{2} \mathrm{~S}\right] \mathrm{MgBr}_{2} / \mathrm{Et}_{2} \mathrm{O} / \mathrm{Me}_{2} \mathrm{~S}$ $(1: 2: 1)$

2) HMPA, THF, EtCOCl, $\mathrm{Pd}\left(\mathrm{PPh}_{3}\right)_{4}$ $82 \%$, Z/E $<1: 99$

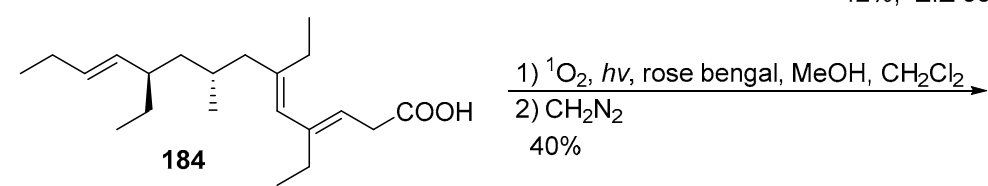<smiles>CC/C=C/C(CC)C[C@H](C)CC1(CC)C=C(CC)C(CC(C)(C)C)OO1</smiles><smiles>CC/C=C/C(CC)C[C@H](C)C[C@]1(CC)C=C(CC)[C@@H](CC(C)=O)OO1</smiles>

Scheme 28. Synthesis of stereoisomeric 1,2-dioxenes 185. 
The cyclic peroxide shuangkangsu (186) isolated from the buds of Lonicera japonica showed high antiviral activity against respiratory syncytial virus on the cell lines and influenza virus in the chicken embryos (Scheme 29) [122].

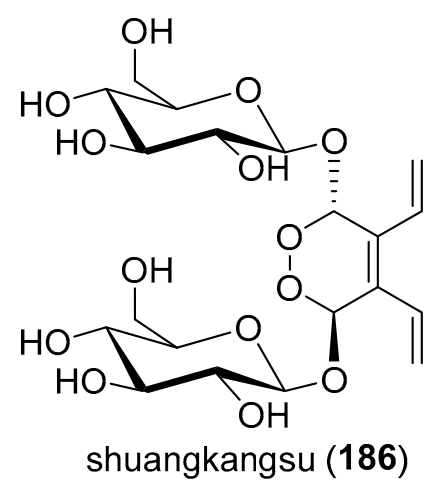

Scheme 29. Peroxide shuangkangsu (186) isolated from Lonicera japonica.

Ergosterol peroxide (187) isolated from different natural sources including the fungi Pycnoporus cinnabarinus demonstrated moderate antiviral activity against Herpes simplex and Polio virus [123], and also antifungal activity against pathogenic fungi Microsporum canis, Trichophyton rubrum and Epidermophyton floccosum (Scheme 30) [124]. Ergosterol peroxide acetate 189 was synthesized with quantitative yield by photo-oxidation of ergosterol acetate 188 in the presence of trityl tetrafluoroborate (Scheme 30) [125].

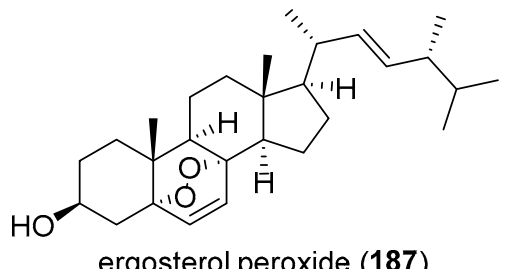

ergosterol peroxide (187)
Herpes simplex virus

Polio virus

Microsporum canis MIC $=10.0 \mu \mathrm{g} / \mathrm{mL}$

Trichophyton rubrum $\mathrm{MIC}=15.0 \mu \mathrm{g} / \mathrm{mL}$

Epidermophyton floccosum MIC $=20.0 \mu \mathrm{g} / \mathrm{mL}$

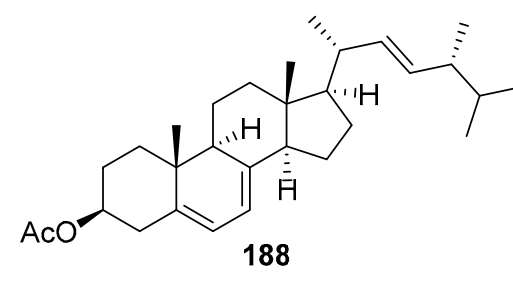

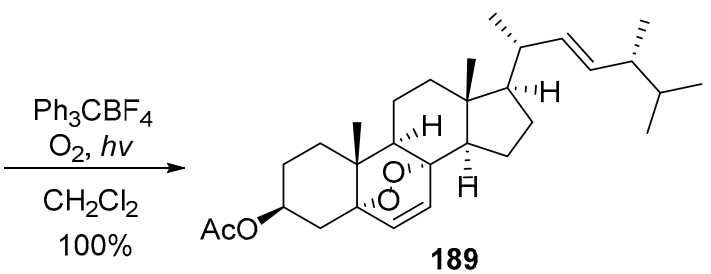

Scheme 30. Ergosterol peroxide (187), exhibited antiviral and antifungal activities and synthesis of its derivatives.

Analogs of ergosterol peroxide without multiple bonds in the side chain $\mathbf{1 9 4}$ were obtained by eosin Y catalyzed photooxidation of steroids 191 followed by hydrolysis and oxidation. Peroxides 194 showed significant ability to inhibit the grown of hepatitis B virus (Scheme 31) [126]. 


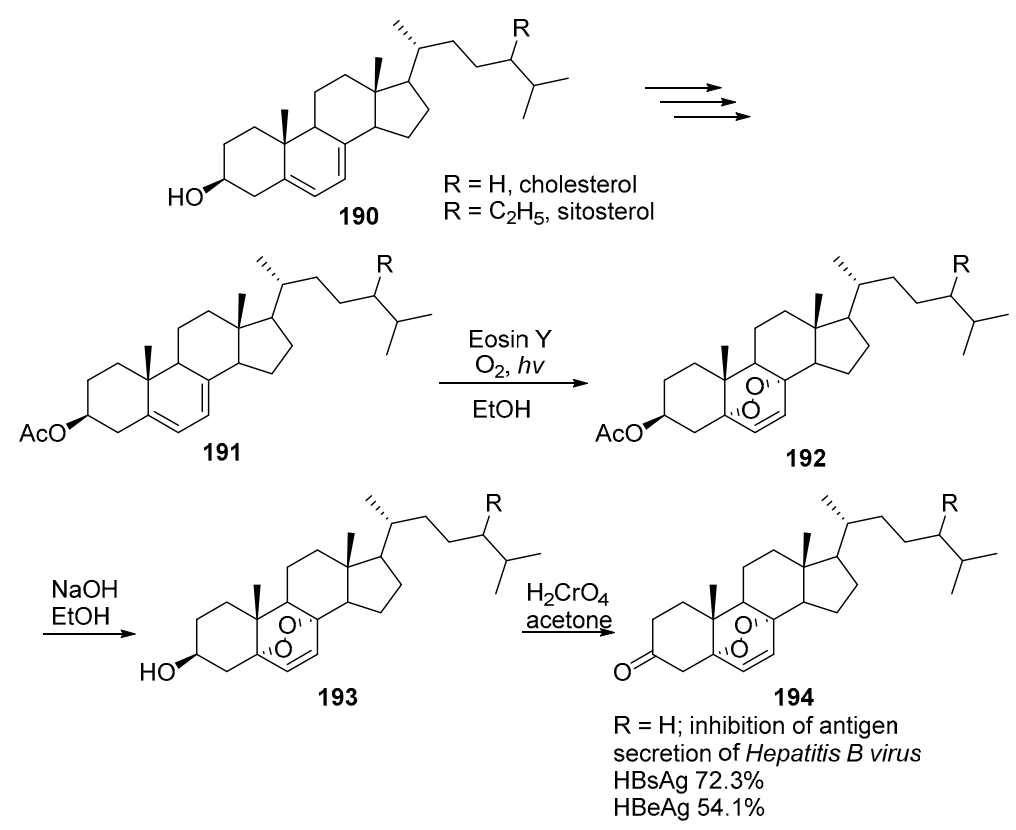

Scheme 31. Synthesis of 194, antiviral analogs of ergosterol peroxide.

A number of 1,2-dioxenes 196 with simpler structure were synthesized from 1,3-butadienes 195. Epoxidation of 196 resulted in 1,2-dioxanes 197 and 198. These peroxides exhibit moderate antifungal activity against Candida family (Scheme 32) [127]. Later, a wide range of derivatives 196, 197 and 198 that inhibits Candida albicans was synthesized [128]. 1,2-Dioxene 196a showed high antifungal activity against C. tropicalis and C. krusei [129].

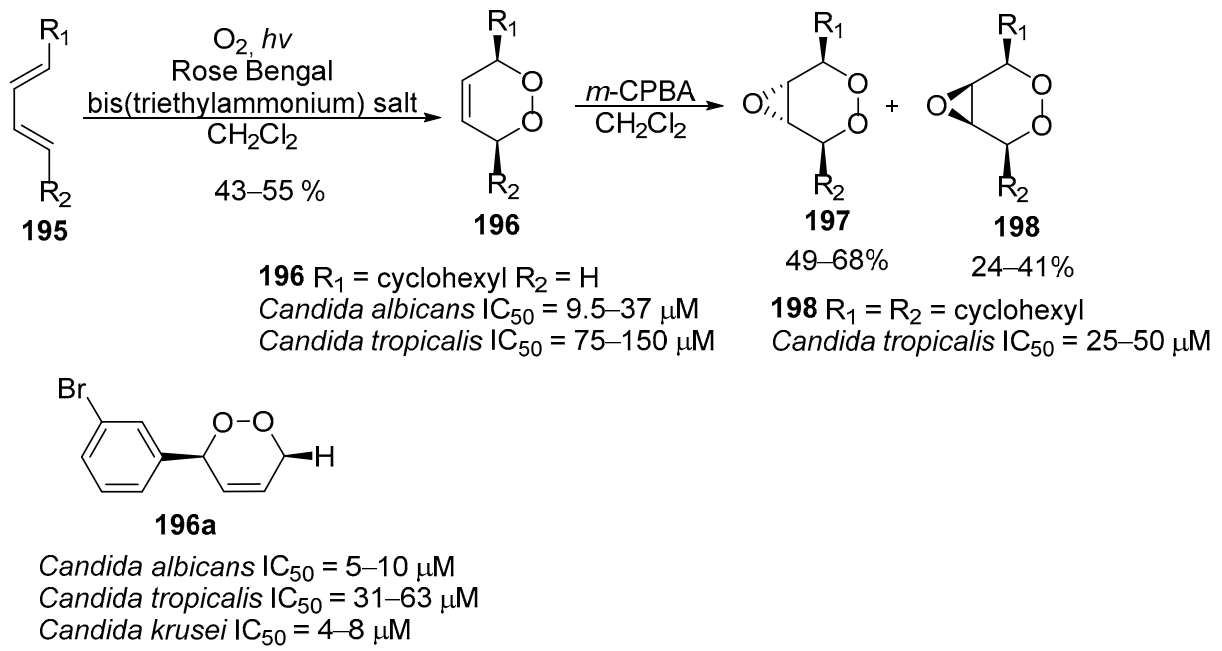

Scheme 32. Synthesis of 1,2-dioxenes 196 and their further modification.

\section{1,2,4-Trioxanes}

Among the class of 1,2,4-trioxane, various aspects of the biological activity of artemisinin and its derivatives are studied most extensively. Synthetic strategies for peroxide ring construction in artemisinin were discussed in detail [130]. Compared with other methods the synthesis of artemisinin (1) based on dihydroartemisinic acid seems most preferable [131], as it can satisfy the demand for cheaper production of sufficient quantities of artemisinin. The key stages of the transformation of dihydroartemisinic acid into artemisinin (1) are described in the fundamental studies of Richard K. Haynes [132]. 
In addition to antimalarial and cytotoxic activity, artemisinin (1) has activity against trypanosomatides Leishmania major [133], Leishmania donovani [134], Trypanosoma brucei rhodesiense and Trypanosoma cruzi [135], as well as parasite Toxoplasma gondii (Scheme 33) [136]. Artemisinin showed a synergistic or additive effect in combination with itraconazole against fungi Aspergillus fumigatus [137], as well as moderate activity against Fusarium oxysporum [138]. Antiviral activity of artemisinin (1) was reported in few studies; inhibition of the human immunodeficiency virus (HIV-1) at $60 \%$ in peripheral blood mononuclear cells [139], the hepatitis C virus (HCV) in human liver cells [140], the bovine viral diarrhea virus (BVDV) [141], as well as hepatitis B virus [142] was shown.

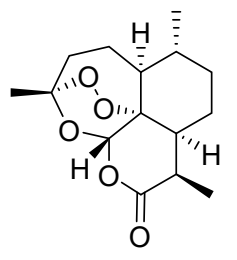

artemisinin (1)
L. major in vitro

promastigotes $\mathrm{ED}_{50}=0.75 \mu \mathrm{M}$

amastigotes $\mathrm{ED}_{50}=30 \mu \mathrm{M}$

L. donovani in vitro

promastigotes $\mathrm{IC}_{50}=160 \mu \mathrm{M}$

amastigotes $\mathrm{IC}_{50}=22 \mu \mathrm{M}$

T. cruzi $\mathrm{IC}_{50}=13.4 \mu \mathrm{M}$

T. brucei rhodesiense $\mathrm{IC}_{50}=20.4 \mu \mathrm{M}$
T. gondii complete elimination at $1.3 \mu \mathrm{g} / \mathrm{mL}$ for 14 days

A. fumigatus $\mathrm{MIC}_{50}=125 \mu \mathrm{g} / \mathrm{mL}$ F. oxysporum inhibition $72 \%$ at $200 \mu \mathrm{g} / \mathrm{mL}$

HIV-1 60\% inhibition $10 \mu \mathrm{M}$ $\mathrm{HCV} \mathrm{EC} \mathrm{E}_{50}=78 \mu \mathrm{M}$

BVDV $60 \%$ inhibition $100 \mu \mathrm{M}$

Scheme 33. Artemisinin and various types of its bioactivity.

Artemisinin derivative, artemether (3), is actively used to treat schistosomiasis, a parasitic disease caused by flat worms of the genus Schistosomiasis [46,47]. A double-blind field trial in the Poyang Lake region (southern China) confirmed that artemether (3) significantly reduces the frequency and intensity of S. japonicum infection and does not cause side effects [143]. Despite the proven pathogenic effects on the reproductive system of Fasciola hepatica [144,145], artemether (3) had practically no effect in the treatment of fascioliasis in humans [146]. Artemether activity against Leishmania major [133], and Toxoplasma gondii $[136,147]$ was detected; it was shown also that artemether is effective in the treatment of experimental rheumatoid arthritis [148,149]. Artemether $(3)$ is obtained by reduction of artemisinin (1) to dihydroartemisinin (2) followed by methylation (Scheme 34) [150,151]. This synthesis can be performed in flow reactor [152,153].

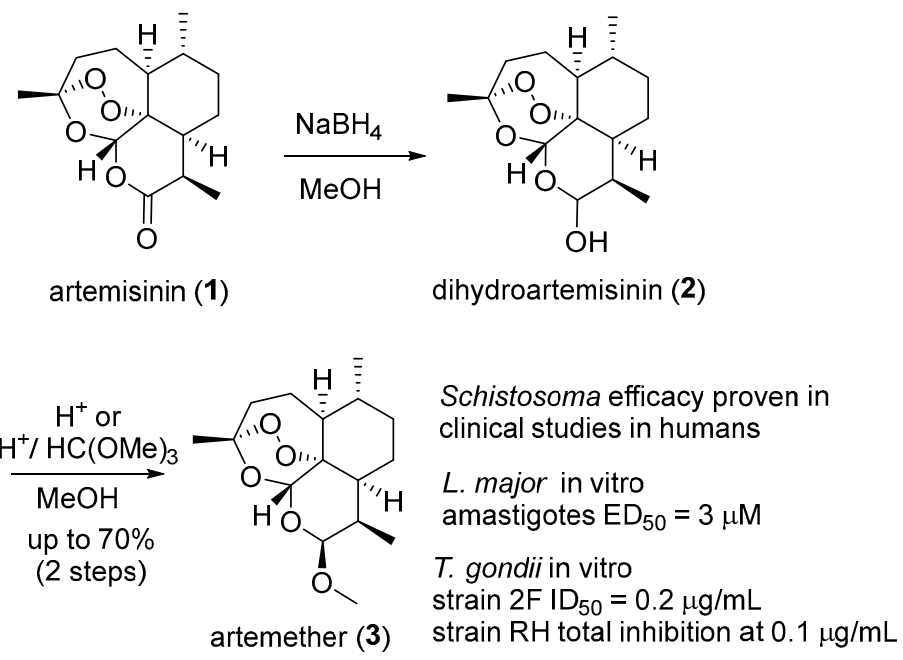

Scheme 34. Synthesis of artemether (3) and its bioactivity.

Artesunate (4), artemisinin derivative containing free carboxylic group showed high efficiency against S. japonicum [154,155], and also in the therapy of fascioliasis caused by Fasciola hepatica or Fasciola gigantica (Scheme 35) [156]. It was determined that artesunate (4) causes changes in the reproductive system of Fasciola hepatica [144]. Antiviral activity of artesunate is displayed 
against the hepatitis B virus [157] and the hepatitis C virus [158], the herpes virus (HHV) type 4 and type 6 [159,160], human cytomegalovirus (HCMV) [161-163], including therapy-resistant mutants of human cytomegalovirus [164]. Artesunate (4) is prepared by reaction of dihydroartemisinin (2) with succinic anhydride in basic conditions (Scheme 35) [152].

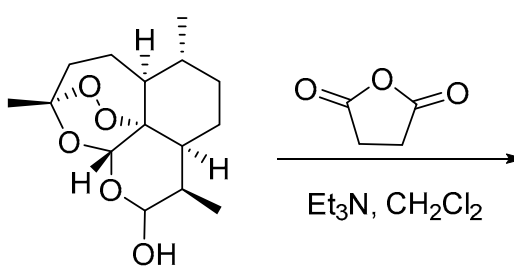

2<smiles>C[C@H]1CC[C@@]2(C)OO[C@@]23[C@H]1CC[C@H](C)[C@@H]3OC(=O)CCC(=O)O</smiles>

artesunate (4)

Schistosoma japonicum efficiency is proven in in vivo studies

Hepatitis $B$ virus antigen $\mathrm{HBsAg} \mathrm{IC}_{50}=2.3 \mu \mathrm{M}$ marker $\mathrm{HBI}$-DNA $\mathrm{IC}_{50}=0.5 \mu \mathrm{M}$

Hepatitis $C$ virus Huh7.5.1 cell line $\mathrm{EC}_{50}=125.8 \mu \mathrm{M}$ therapy-resistant $H C M V I C_{50}=4.4 \mu \mathrm{M}$ OR6 cell line $\mathrm{EC}_{50}=10.8 \mu \mathrm{M}$

Fasciola efficiency is proven in clinical trials

$H H V-4 \mathrm{IC}_{50}=3.8 \mu \mathrm{M}$

HHV $-6 \mathrm{IC}_{50}=7.2 \mu \mathrm{M}$

efficiency is proven in clinical trials

HCMV strain AD169 IC $\mathrm{I}_{50}=3.7 \mu \mathrm{M}$ or $5.6 \mu \mathrm{M}$

HCMV strain VI1210 IC $\mathrm{I}_{50}=5.2 \mu \mathrm{M}$

Scheme 35. Synthesis of artesunate (4) and its bioactivity.

The library of 10-deoxo-derivativies of artemisinin 205 showed high activity against parasites Leishmania donovani (Scheme 36). Synthesis of $\mathbf{2 0 5}$ was performed from artemisitene $\mathbf{1 9 9}$ by radical addition of compound $\mathbf{2 0 0}$ followed by reduction of carbonyl group in 202. Dehydration and deprotection resulted in phenol 204, which formed a series of compounds 205 by reaction with derivatives of carboxylic and sulfonic acids [165].
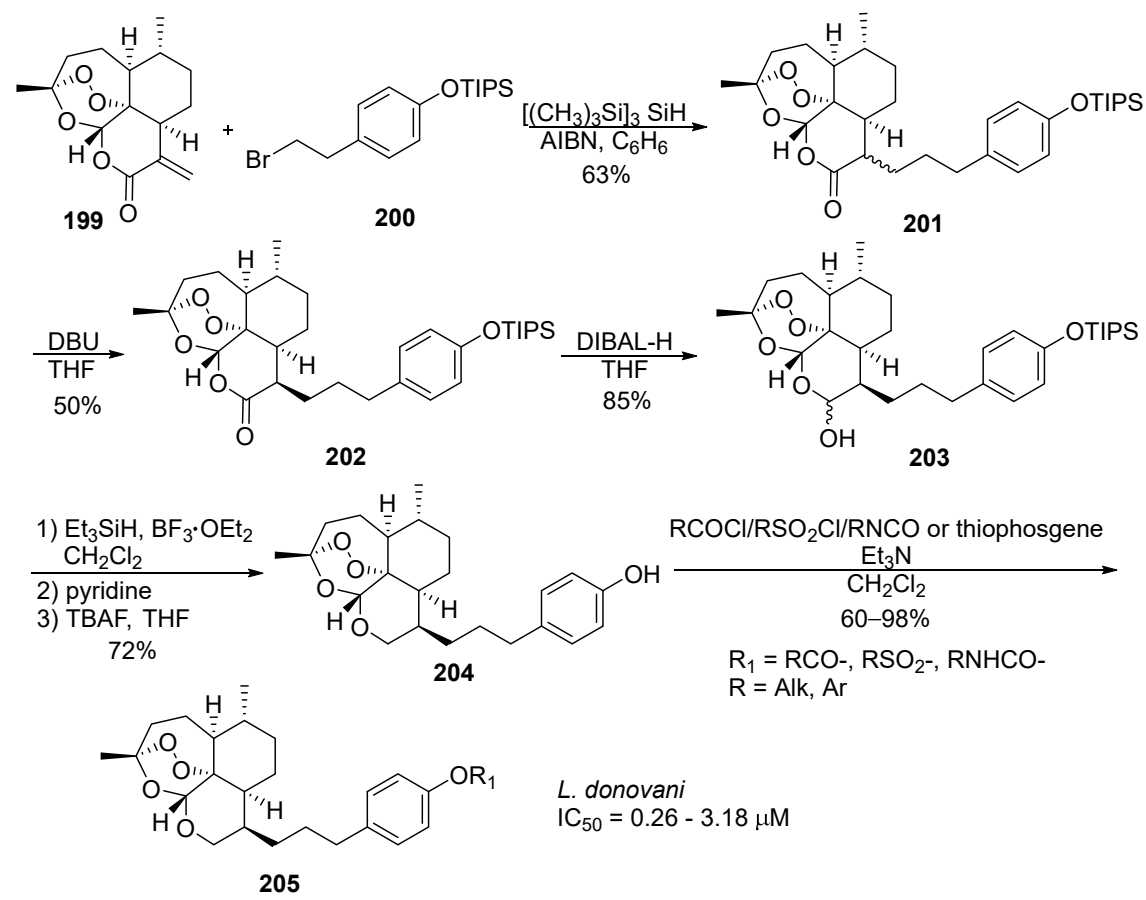

Scheme 36. Antileishmaniasis derivatives of artemisinin 205. 
Attempts to synthesize the antitoxoplasma derivatives of artemisinin have been made $[147,166]$, however their in vitro activity did not exceed the activity of artemether (3).

Among artemisinin derivatives tested for fungicidal activity, anhydrodihydroartemisinin (206) and arteether (207) were most active against Cryptoccocus neoformans [167], their activity surpassed the one of amphotericin B. Both derivatives were obtained [168,169] in one step from dihydroartemisinin (2) (Scheme 37). Later it was found that arteether (207) [170] exhibits moderate antiviral activity against human immunodeficiency virus and anhydrodihydroartemisinin (206) [171] is high active against hepatitis B virus.

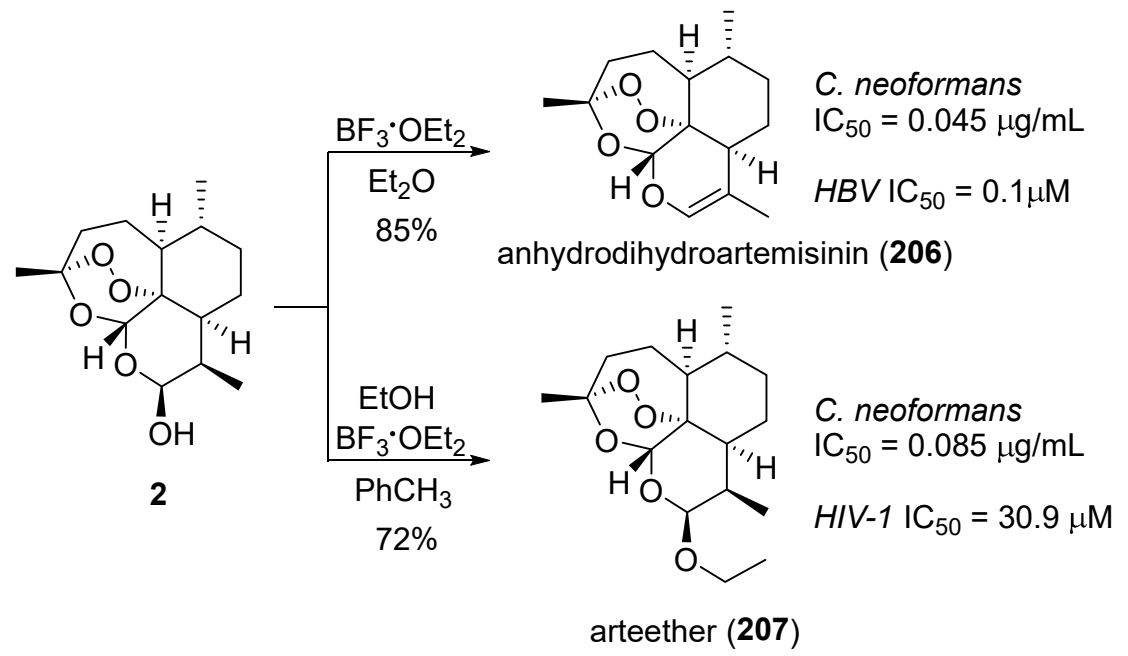

Scheme 37. Antifungal and antiviral artemisinin derivatives— anhydrodihydroartemisinin (206) and arteether (207).

High antiviral activity against human immunodeficiency virus [170] was demonstrated by butyl-derivative of artemisinin 209, prepared via photo-oxidation of alcohol 208 with $12 \%$ yield (Scheme 38) [172].<smiles>CC1=CC2C(CC[C@@H]2C)CC[C@H]1C(C)C(O)c1ccccc1</smiles>

208
1) $\mathrm{O}_{2} h v, \mathrm{CH}_{2} \mathrm{Cl}_{2}$ methylene blue

2) Dowex resin $\mathrm{C}_{6} \mathrm{H}_{14}$ $12 \%$

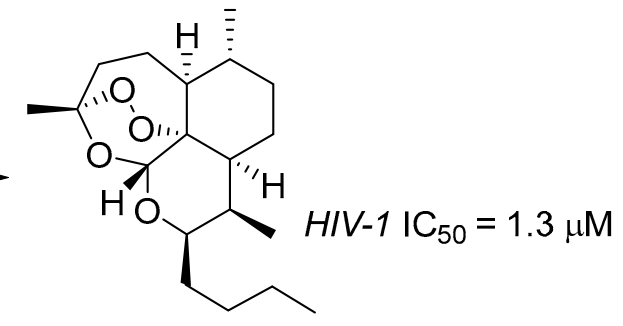

209

Scheme 38. Antiviral artemisinin derivative 209.

Combination of dihydroartemisinin (2) with antiviral drug azidothymidine (210) resulted in compound 211 exhibited both antimalarial as antiviral activity (Scheme 39) [173].

A new trend in the medical chemistry of artemisinin derivatives is the synthesis of dimers and trimers. Among a series of artemisinin dimers obtained by condensation of dihydroartemisinin (2) with binucleophile, compounds $\mathbf{2 1 2}$ and $\mathbf{2 1 3}$ showed the highest activity against fungi Cryptococcus neoformans and parasites Leishmania donovani, respectively (Scheme 40) [174]. 


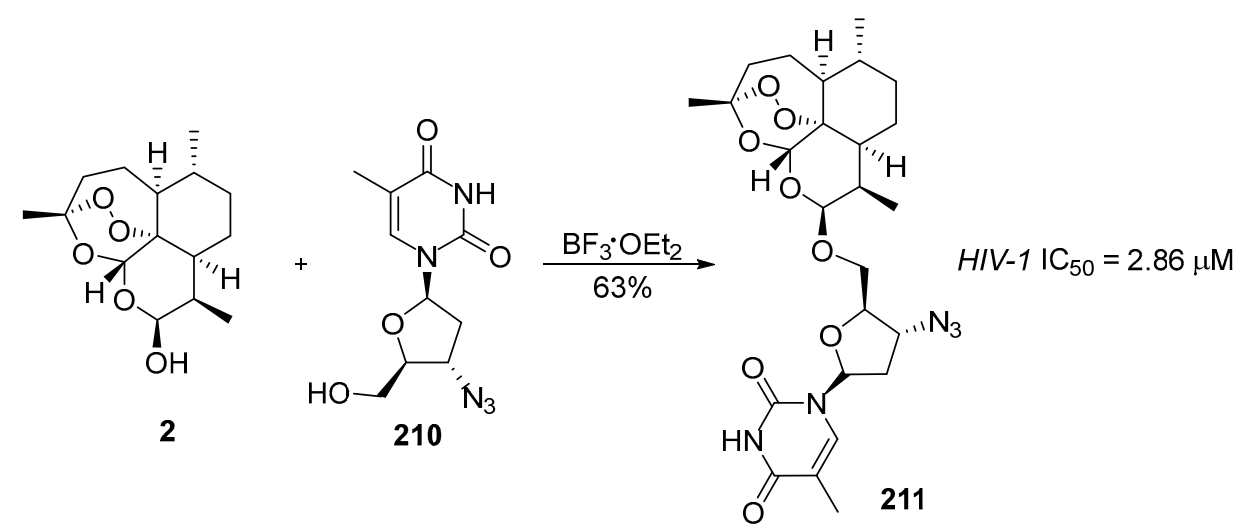

Scheme 39. Synthesis of hybrid 211 based on dihydroartemisinin 2 and azidothymidine 210.

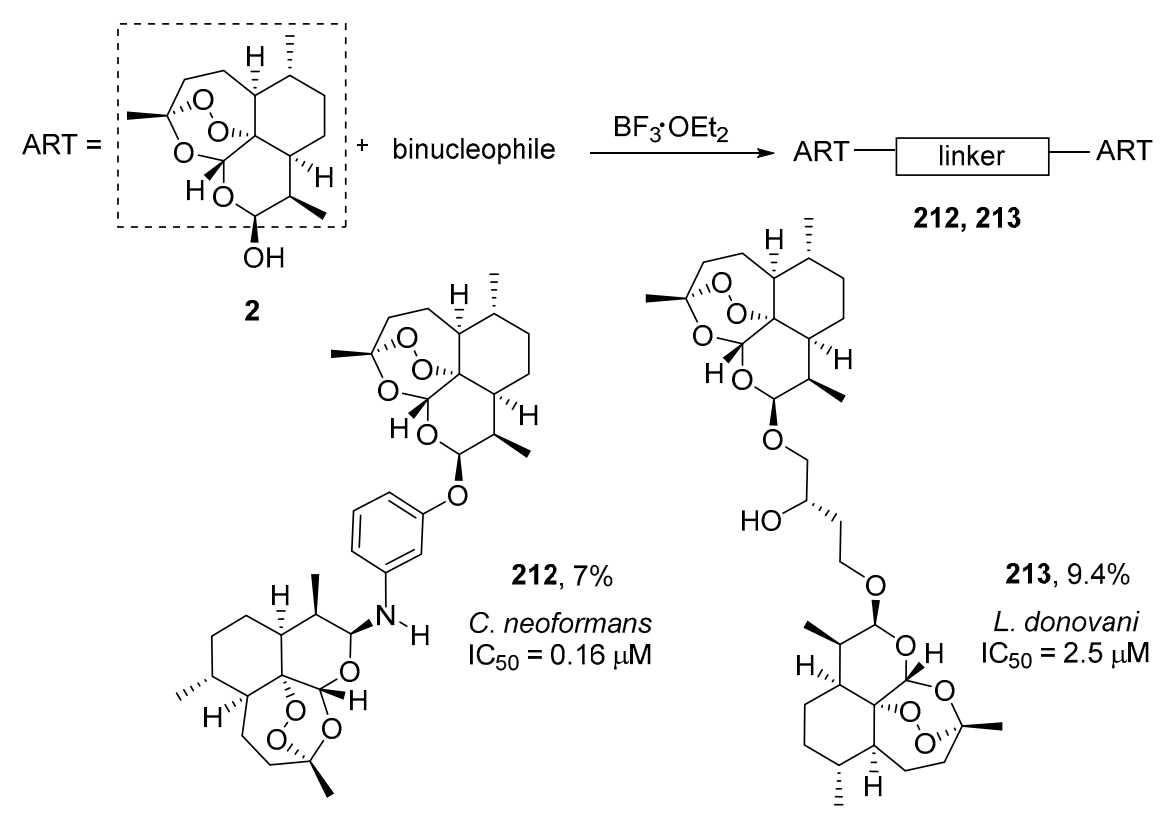

Scheme 40. Synthesis of artemisinin dimers 212 and 213 with antifungal and anti-parasitic activity.

Dimers and trimers of artemisinin showed antiviral activity were summarized in Table 1.

Table 1. Dimers and trimers of artemisinin showed antiviral activity.

\begin{tabular}{|c|c|c|c|}
\hline No. & Dimer/Trimer Structure & Synthesis & Bioactivity \\
\hline 1 & $\underbrace{A R T}_{214}$ & $\begin{array}{l}\text { from artemisinin (1) } \\
3 \text { steps, } 67 \% \text { [175] }\end{array}$ & $\begin{array}{c}H C M V \mathrm{EC}_{50}=0.15 \mu \mathrm{M} \\
{[176,177]}\end{array}$ \\
\hline 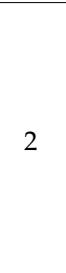 & $\underbrace{}_{215}{ }_{215} \mathrm{CH}_{2} \mathrm{OC}($ & $\begin{array}{l}\text { from } 2143 \text { steps, } \\
\quad 42 \%[178]\end{array}$ & $H C M V \mathrm{EC}_{50}=0.06 \mu \mathrm{M}[176]$ \\
\hline
\end{tabular}


Table 1. Cont

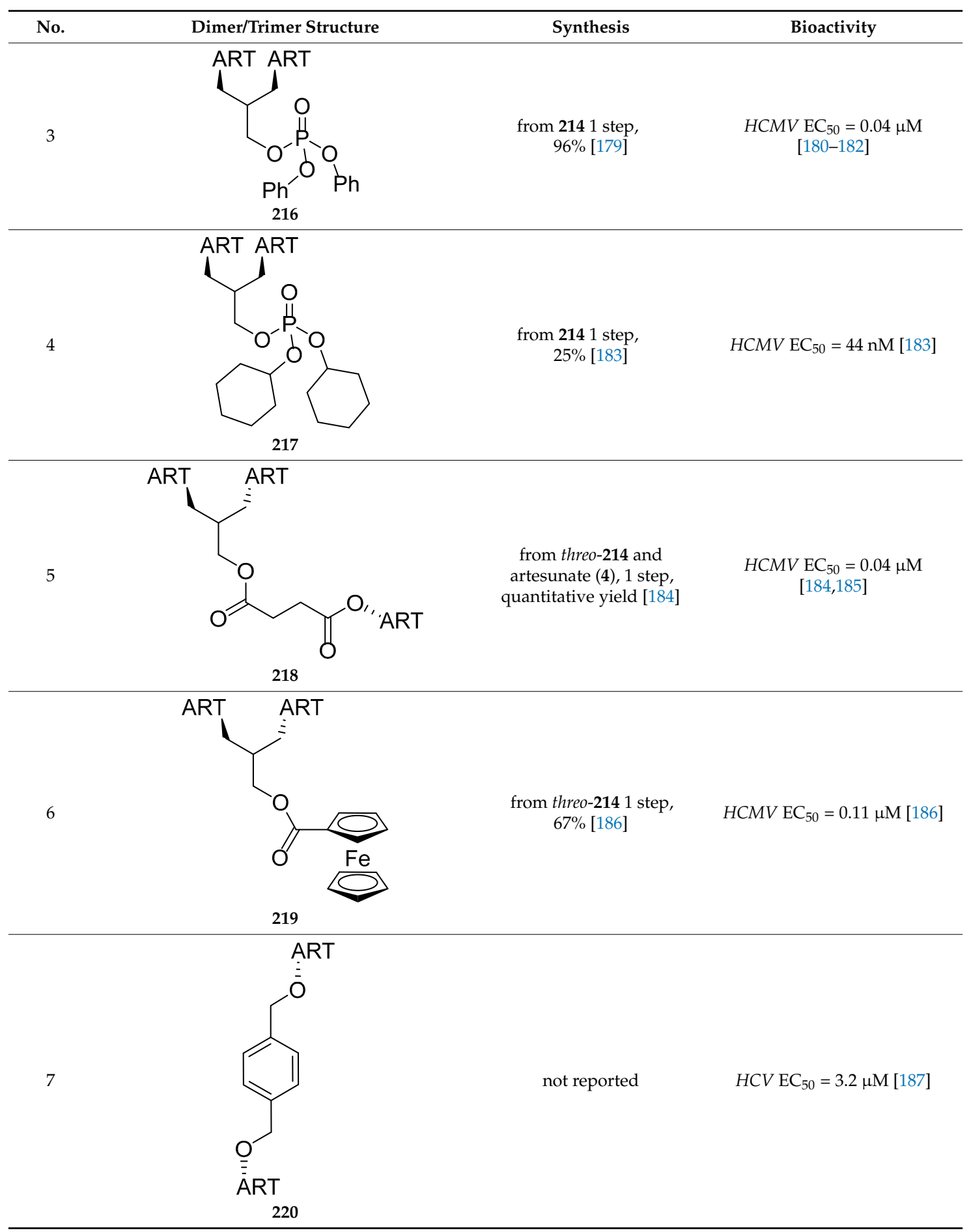

Synthetic 1,2,4-trioxanes 223 obtained by condensation of hydroxy-hydroperoxide 221 with adamantane followed by hydrolysis of ester $\mathbf{2 2 2}$ showed high in vivo activity against helminths Fasciola hepatica in rats (Scheme 41) [188]. 


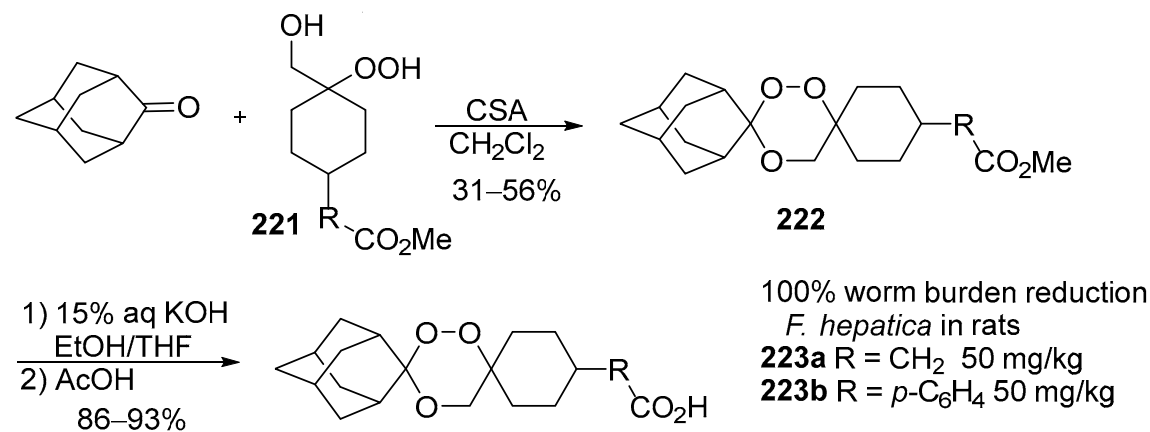

223

Scheme 41. Anthelminthic activity of synthetic 1,2,4-trioxanes 223.

\section{1,2,4,5-Tetraoxanes}

Synthetic 1,2,4,5-tetraoxane 226 [189], prepared by condensation of bis-hydroperoxide 224 with adamantanone followed by hydrolysis ester 225, showed high in vivo activity against helminths Fasciola hepatica in rats (Scheme 42) [188].

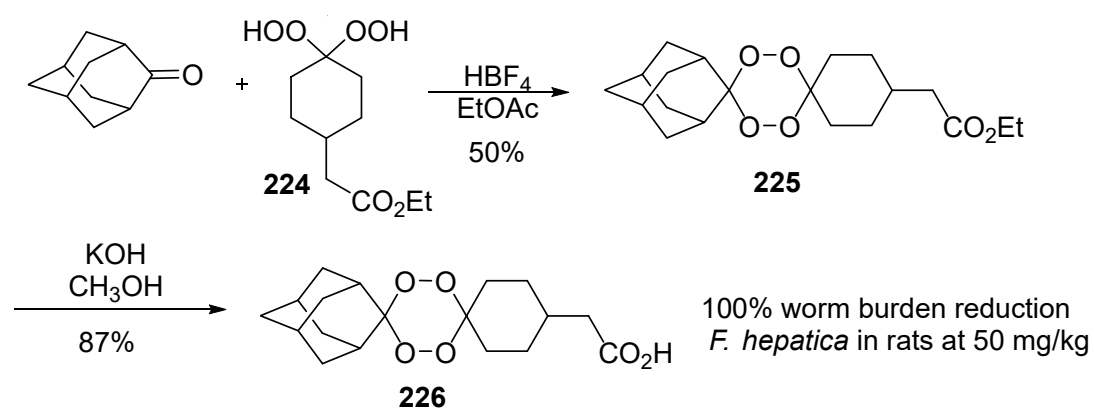

Scheme 42. Synthesis of 1,2,4,5-tetraoxane 226 with high anthelmintic activity.

Based on related 1,2,4,5-tetraoxanes 227, hybrids 229 with a fragment of an anthelmintic drug praziquantel 228 were obtained (Scheme 43) [190]. Synthesized hybrids 229 exhibit high activity against Schistosoma japonicum and Schistosoma mansoni [191].
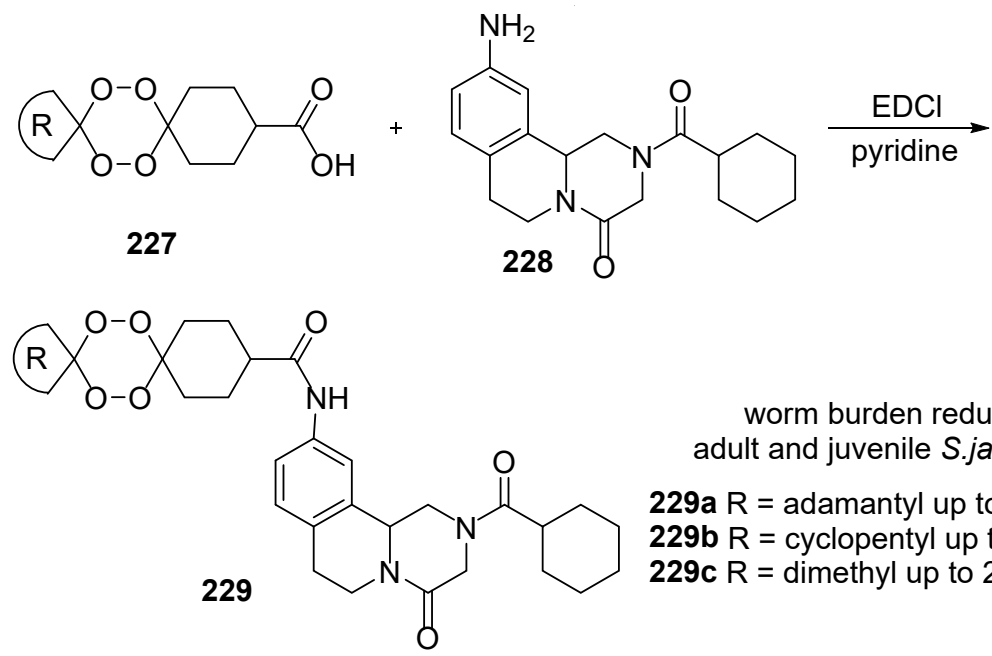

worm burden reduction adult and juvenile S.japonicum

Scheme 43. Synthesis of hybrids 229 as anti-schistosomal agents. 
Bridged 1,2,4,5-tetraoxanes 231 demonstrated high in vitro and in vivo activity against trematodes Schistosoma mansoni $[74,192]$. The best result was shown for adamantane-substituted tetraoxane 231a which caused $75 \%$ worm burden reductions in $S$. mansoni harbored in mice following the administration of peroxide at single oral dose of $400 \mathrm{mg} / \mathrm{kg}$. Peroxides $\mathbf{2 3 1}$ were synthesized from $\beta$-diketones $\mathbf{2 3 0}$ and $\mathrm{H}_{2} \mathrm{O}_{2}$ with good yields by the action of various acids: sulfuric [193], phosphomolybdic and phosphotungstic acids [194] (Scheme 44).<smiles>[R]C(C(C)=O)C(C)=O</smiles>

230

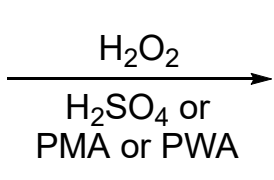

$41-83 \%$<smiles>[R]C1OOC2(C)OOC1(C)OO2</smiles>

231

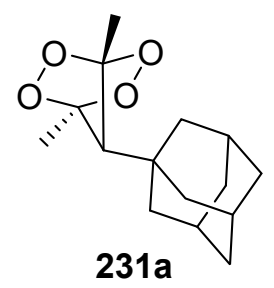

in vitro

adult $S$. mansoni $\mathrm{IC}_{50}=0.3 \mu \mathrm{M}$

NTS S. mansoni $I C_{50}=0.1 \mu \mathrm{M}$

in vivo

$75 \%$ worm burden reduction

Scheme 44. Synthesis of bridged 1,2,4,5-tetraoxanes 231 .

\section{Acyclic Peroxides}

Many acyclic peroxides are applied as oxidants in organic synthesis [195,196]. Benzoyl peroxide (234) is actively used in the food industry as a flour bleach [197-199], and in pharmaceuticals. The first mention about the medical using of benzoyl peroxide dates back to 1929, where Lyon and Reynolds reported effective treatment of burns, wounds and varicose veins by benzoyl peroxide [200]. Subsequently it was found that it has antibacterial [201,202], anti-inflammatory [203], cheratolic [204], and wound-healing $[205,206]$ effects. Presently, benzoyl peroxide is widely used agent for acne treatment because of its efficacy and good tolerability in patients $[207,208]$. Benzoyl peroxide is a good alternative to monotherapy with antibiotics for the treatment of Acne vulgaris caused antibiotic-resistant strains, for example Propionibacterium acnes [209,210].

Benzoyl peroxide is commercially produced by the reaction of benzoyl chloride (232), sodium hydroxide and hydrogen peroxide (Scheme 45, top) [211,212]. Benzoyl peroxide can also be prepared from benzoic anhydride (233) by the action of an alkali metal perborate in an aqueous solution (Scheme 45, bottom) [213].

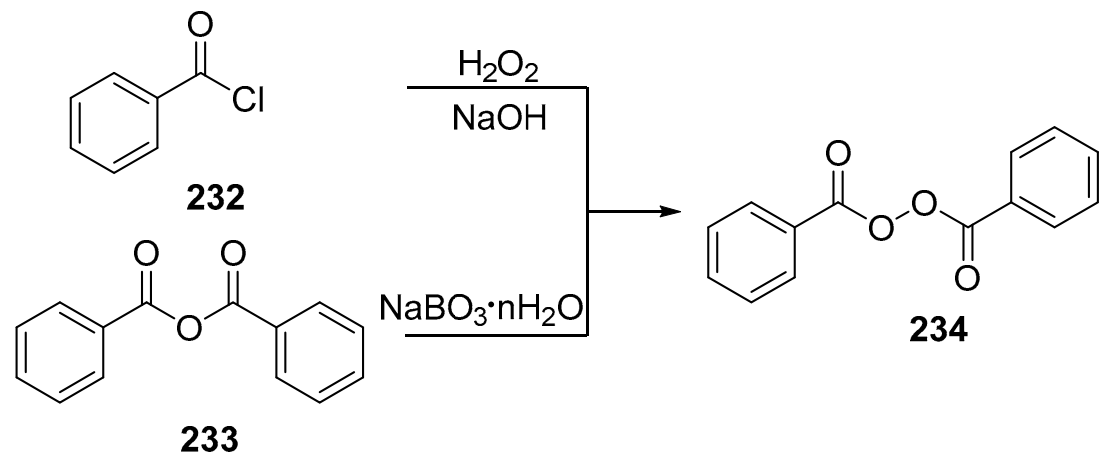

Scheme 45. Benzoyl peroxide (234) production.

Oxanthromicin (235) isolated from bacteria Actinomadura sp. [214] showed high antifungal activity against Trichophyton mentagrophytes, Micosporum canis, M. gypseum, Epidermophyton floccosum, Candida albicans, and Aspergillus niger (Scheme 46) [215]. 


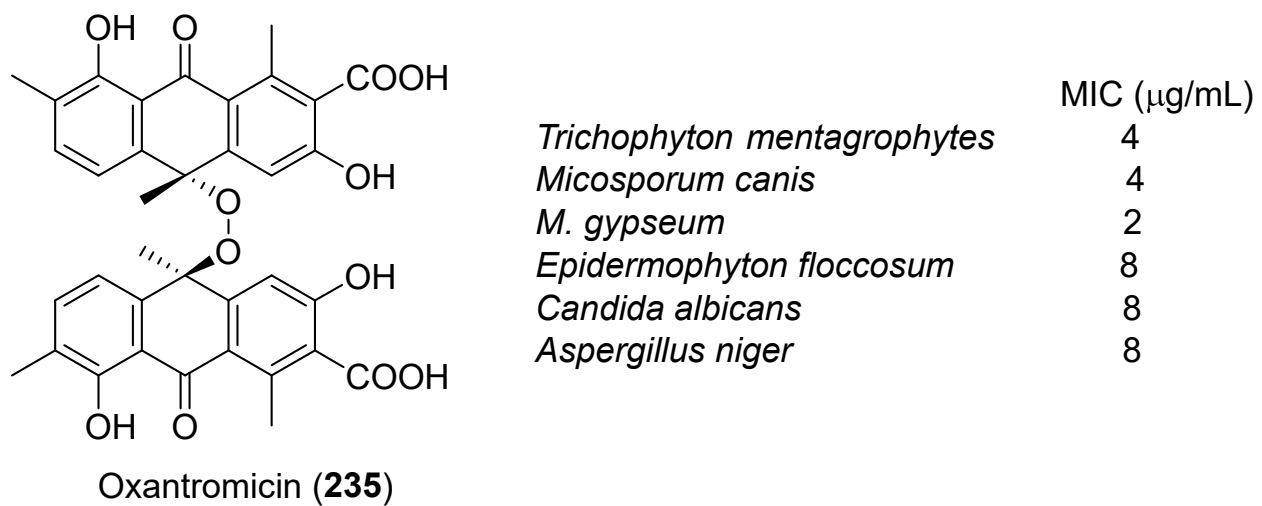

Scheme 46. Antifungal natural acyclic peroxide, oxanthromicin (235).

Hydroperoxide $\mathbf{2 3 6}$ obtained by biotransformation of Artemisia cina metabolites exhibits high in vitro activity against protozoa Trypanosoma brucei (Scheme 47) [216].

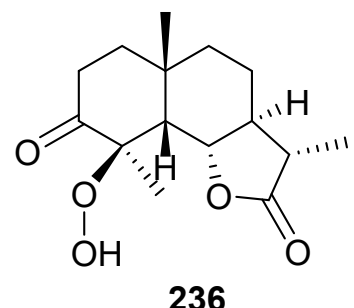

Tripanosoma brucei $\mathrm{EC}_{50}(\mu \mathrm{g} / \mathrm{mL}) 0.40$

Scheme 47. Anti-trypanosomal hydroperoxide 236.

Four monoterpene hydroperoxides $\mathbf{2 3 7} \mathbf{a}-\mathbf{d}$ were isolated from aerial parts of Chenopodium ambrosioides. Minimum lethal concentration (MLC) in vitro of its peroxides against Trypanosoma cruzi was 1.2, 1.6, 3.1, and $0.8 \mu \mathrm{M}$, respectively (Scheme 48) [107].<smiles>O=O</smiles><smiles>C=C1CCC(C(=C)C)CC1</smiles>

237a<smiles>C=C1CCCCC1OO</smiles><smiles>C=C(C)C</smiles>

237b<smiles>C[C@]1(O)C=CCCC1</smiles><smiles>C=C(C)C</smiles>

$237 c$<smiles>C=C(C)[C@H]1C=C[C@@](C)(O)CC1</smiles>

237d

1.2

Tripanosoma cruzi MLC $(\mu \mathrm{M})$

1.6

3.1

0.8

Scheme 48. Hydroperoxides $\mathbf{2 3 7} \mathbf{a}-\mathbf{d}$ isolated from Chenopodium ambrosioides.

A geminal bis-hydroperoxides 239 synthesized from cyclic ketones 238 show pronounced in vitro antimicrobial and antifungal activity against B. cereus, E. coli, P. aeruginosa, S. aureus, C. albicans, and $A$. niger comparable with the effect of some antiseptics and, to a lesser extent, antibiotics (Scheme 49) [217]. 

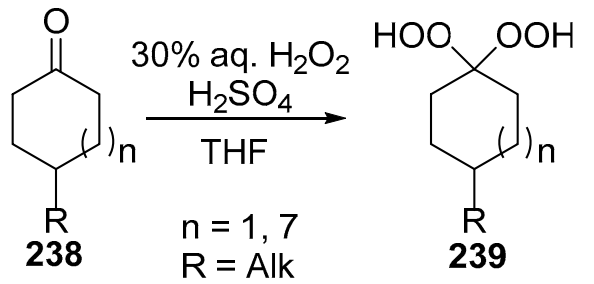

B. cereus
E. coli
Ps. aeruginosa
St. aureus
C. albicans
A. niger

$\mathrm{MIC}, \mathrm{mg} / \mathrm{mL}$
$0.1-1$
$0.1-1$
$1-10$
1
$1-10$
$0.1-10$

Scheme 49. Antimicrobial and antifungal geminal bis-hydroperoxides 239.

\section{Conclusions}

The biological activity of organic peroxides is usually associated with the antimalarial properties of artemisinin and its derivatives. However, the analysis of published data indicates that organic peroxides exhibit a variety of biological activity - anthelmintic, antifungal, antiviral, etc.- - which is still being given insufficient attention.

Efforts of synthetic chemists are currently directed at the development of methods for the synthesis of biologically active natural peroxides, the modification of natural peroxides and the search of synthetic peroxides, which are not inferior to their natural and semisynthetic analogs, but are substantially cheaper. It seems that progress in the synthesis of biologically active peroxides will be mainly related to the last two directions.

In view of very dynamic development of these areas of medical chemistry, in the near future, one should expect a breakthrough in the synthesis of biologically active peroxides and in understanding of its action with respect to a wide range of bio-targets.

Acknowledgments: The authors are grateful to the Russian Science Foundation (Grant 17-73-10364) for the financial support.

Author Contributions: All authors have contributed substantially: V.A.V., I.A.Y., I.A.I. and A.O.T. wrote the manuscript; and V.A.V. and I.A.Y. researched the literature and wrote the manuscript.

Conflicts of Interest: The authors declare no conflict of interest.

\section{References}

1. Patnaik, P. Peroxides, organic. In A Comprehensive Guide to the Hazardous Properties of Chemical Substances; John Wiley \& Sons, Inc.: Hoboken, NJ, USA, 2006; pp. 719-740.

2. Liebman, J.F.; Greer, A. The Chemistry of Peroxides; John Wiley \& Sons: Hoboken, NJ, USA, 2006; Volume 3.

3. Klapötke, T.M.; Wloka, T. Peroxide explosives. In Patai's Chemistry of Functional Groups; John Wiley \& Sons, Ltd.: Hoboken, NJ, USA, 2009.

4. Denisov, E.T.; Denisova, T.G.; Pokidova, T.S. Diacyl peroxides, peroxy esters, polyatomic, and organometallic peroxides. In Handbook of Free Radical Initiators; John Wiley \& Sons, Inc.: Hoboken, NJ, USA, 2005; pp. 129-282.

5. Gaylord, N.G.; Mandal, B.M.; Martan, M. Peroxide-induced polymerization of norbornene. J. Polym. Sci. Polym. Lett. Ed. 1976, 14, 555-559. [CrossRef]

6. Emami, S.H.; Salovey, R.; Hogen-Esch, T.E. Peroxide-mediated crosslinking of poly(ethylene oxide). J. Polym. Sci. Part A Polym. Chem. 2002, 40, 3021-3026. [CrossRef]

7. Russell, K.E. Free radical graft polymerization and copolymerization at higher temperatures. Prog. Polym. Sci. 2002, 27, 1007-1038. [CrossRef]

8. Adam, W. Peroxide Chemistry: Mechanistic and Preparative Aspects of Oxygen Transfer; Wiley-VCH Verlag GmbH \& Co. KGaA: Weinheim, Germany, 2005.

9. Mishra, M.; Yagci, Y. Handbook of Vinyl Polymers: Radical Polymerization, Process, and Technology, 2nd ed.; CRC Press, Taylor \& Francis Group: Boca Raton, FL, USA, 2008; p. 784.

10. Ukuku, D.O.; Bari, L.; Kawamoto, S. Hydrogen peroxide. In Decontamination of Fresh and Minimally Processed Produce; Wiley-Blackwell: Hoboken, NJ, USA, 2012; pp. 197-214.

11. Kitis, M. Disinfection of wastewater with peracetic acid: A review. Environ. Int. 2004, 30, 47-55. [CrossRef] 
12. Chassot, A.L.C.; Poisl, M.I.P.; Samuel, S.M.W. In vivo and in vitro evaluation of the efficacy of a peracetic acid-based disinfectant for decontamination of acrylic resins. Braz. Dent. J. 2006, 17, 117-121. [CrossRef] [PubMed]

13. Baldry, M.G.C.; French, M.S. Disinfection of sewage effluent with peracetic acid. Water Sci. Technol. 1989, 21, 203-206.

14. Alvaro, J.E.; Moreno, S.; Dianez, F.; Santos, M.; Carrasco, G.; Urrestarazu, M. Effects of peracetic acid disinfectant on the postharvest of some fresh vegetables. J. Food Eng. 2009, 95, 11-15. [CrossRef]

15. McDonnell, G. The use of hydrogen peroxide for disinfection and sterilization applications. In Patai's Chemistry of Functional Groups; John Wiley \& Sons, Ltd.: Hoboken, NJ, USA, 2009.

16. Omidbakhsh, N. A new peroxide-based flexible endoscope-compatible high-level disinfectant. Am. J. Infect. Control 2006, 34, 571-577. [CrossRef] [PubMed]

17. Luukkonen, T.; Pehkonen, S.O. Peracids in water treatment: A critical review. Crit. Rev. Environ. Sci. Technol. 2017, 47, 1-39. [CrossRef]

18. Mao, W.; Zhang, Y.; Zhang, A. Discovery of antimalarial drug artemisinin and beyond. In Case Studies in Modern Drug Discovery and Development; John Wiley \& Sons, Inc.: Hoboken, NJ, USA, 2012; pp. 227-256.

19. Tu, Y. The discovery of artemisinin (qinghaosu) and gifts from Chinese medicine. Nat. Med. 2011, 17, 1217-1220. [CrossRef] [PubMed]

20. White, N.J.; Hien, T.T.; Nosten, F.H. A brief history of qinghaosu. Trends Parasitol. 2015, 31, $607-610$. [CrossRef] [PubMed]

21. Xu, T.; Feng, Q.; Jacob, M.R.; Avula, B.; Mask, M.M.; Baerson, S.R.; Tripathi, S.K.; Mohammed, R.; Hamann, M.T.; Khan, I.A.; et al. The marine sponge-derived polyketide endoperoxide plakortide $\mathrm{f}$ acid mediates its antifungal activity by interfering with calcium homeostasis. Antimicrob. Agents Chemother. 2011, 55, 1611-1621. [CrossRef] [PubMed]

22. Tu, Y.Y.; Ni, M.Y.; Zhong, Y.R.; Li, L.N.; Cui, S.L.; Zhang, M.Q.; Wang, X.Z.; Liang, X.T. Studies on the constituents of artemisia annua 1. (author's transl). Yao Xue Xue Bao 1981, 16, 366-370. [PubMed]

23. Miller, L.H.; Su, X. Artemisinin: Discovery from the Chinese herbal garden. Cell 2011, 146, 855-858. [CrossRef] [PubMed]

24. Robert, A.; Dechy-Cabaret, O.; Cazelles, J.; Meunier, B. From mechanistic studies on artemisinin derivatives to new modular antimalarial drugs. Acc. Chem. Res. 2002, 35, 167-174. [CrossRef] [PubMed]

25. Gelb, M.H. Drug discovery for malaria: A very challenging and timely endeavor. Curr. Opin. Chem. Biol. 2007, 11, 440-445. [CrossRef] [PubMed]

26. Capela, R.; Oliveira, R.; Gonçalves, L.M.; Domingos, A.; Gut, J.; Rosenthal, P.J.; Lopes, F.; Moreira, R. Artemisinin-dipeptidyl vinyl sulfone hybrid molecules: Design, synthesis and preliminary sar for antiplasmodial activity and falcipain-2 inhibition. Bioorg. Med. Chem. Lett. 2009, 19, 3229-3232. [CrossRef] [PubMed]

27. Jones, M.; Mercer, A.E.; Stocks, P.A.; La Pensée, L.J.I.; Cosstick, R.; Park, B.K.; Kennedy, M.E.; Piantanida, I.; Ward, S.A.; Davies, J.; et al. Antitumour and antimalarial activity of artemisinin-acridine hybrids. Bioorg. Med. Chem. Lett. 2009, 19, 2033-2037. [CrossRef] [PubMed]

28. White, N.J. Qinghaosu (artemisinin): The price of success. Science 2008, 320, 330-334. [CrossRef] [PubMed]

29. Shah, F.; Zhang, S.-Q.; Kandhari, S.P.; Mukherjee, P.; Chittiboyina, A.; Avery, M.A.; Avery, B.A. In vitro erythrocytic uptake studies of artemisinin and selected derivatives using lc-ms and 2d-qsar analysis of uptake in parasitized erythrocytes. Bioorg. Med. Chem. 2009, 17, 5325-5331. [CrossRef] [PubMed]

30. Mäser, P.; Wittlin, S.; Rottmann, M.; Wenzler, T.; Kaiser, M.; Brun, R. Antiparasitic agents: New drugs on the horizon. Curr. Opin. Pharmacol. 2012, 12, 562-566. [CrossRef] [PubMed]

31. Dembitsky, V.M. Bioactive peroxides as potential therapeutic agents. Eur. J. Med. Chem. 2008, 43, $223-251$. [CrossRef] [PubMed]

32. Ibrahim, S.R.M.; Ebel, R.; Wray, V.; Müller, W.E.G.; Edrada-Ebel, R.; Proksch, P. Diacarperoxides, norterpene cyclic peroxides from the sponge diacarnus megaspinorhabdosa. J. Nat. Prod. 2008, 71, 1358-1364. [CrossRef] [PubMed]

33. Liu, D.-Z.; Liu, J.-K. Peroxy natural products. Nat. Prod. Bioprospect. 2013, 3, 161-206. [CrossRef]

34. Li, H.; Huang, H.; Shao, C.; Huang, H.; Jiang, J.; Zhu, X.; Liu, Y.; Liu, L.; Lu, Y.; Li, M.; et al. Cytotoxic norsesquiterpene peroxides from the endophytic fungus talaromyces flavus isolated from the mangrove plant sonneratia apetala. J. Nat. Prod. 2011, 74, 1230-1235. [CrossRef] [PubMed] 
35. Meshnick, S.R.; Jefford, C.W.; Posner, G.H.; Avery, M.A.; Peters, W. Second-generation antimalarial endoperoxides. Parasitol. Today 1996, 12, 79-82. [CrossRef]

36. Ploypradith, P. Development of artemisinin and its structurally simplified trioxane derivatives as antimalarial drugs. Acta Trop. 2004, 89, 329-342. [CrossRef] [PubMed]

37. Tang, Y.; Dong, Y.; Vennerstrom, J.L. Synthetic peroxides as antimalarials. Med. Res. Rev. 2004, 24, 425-448. [CrossRef] [PubMed]

38. Jefford, C.W. New developments in synthetic peroxidic drugs as artemisinin mimics. Drug Discov. Today 2007, 12, 487-495. [CrossRef] [PubMed]

39. Opsenica, D.M.; Šolaja, B.A. Antimalarial peroxides. J. Serb. Chem. Soc. 2009, 74, 1155-1193. [CrossRef]

40. Dembitsky, V.M.; Gloriozova, T.A.; Poroikov, V.V. Natural peroxy anticancer agents. Mini Rev. Med. Chem. 2007, 7, 571-589. [CrossRef] [PubMed]

41. Jung, M.; Kim, H.; Lee, K.; Park, M. Naturally occurring peroxides with biological activities. Mini Rev. Med. Chem. 2003, 3, 159-165. [CrossRef] [PubMed]

42. Chaturvedi, D.; Goswami, A.; Pratim Saikia, P.; Barua, N.C.; Rao, P.G. Artemisinin and its derivatives: A novel class of anti-malarial and anti-cancer agents. Chem. Soc. Rev. 2010, 39, 435-454. [CrossRef] [PubMed]

43. Lee, S. Artemisinin, promising lead natural product for various drug developments. Mini Rev. Med. Chem. 2007, 7, 411-422. [CrossRef] [PubMed]

44. Pandey, N.; Pandey-Rai, S. Updates on artemisinin: An insight to mode of actions and strategies for enhanced global production. Protoplasma 2016, 253, 15-30. [CrossRef] [PubMed]

45. Yao, W.; Wang, F.; Wang, H. Immunomodulation of artemisinin and its derivatives. Sci. Bull. 2016, 61, $1399-1406$. [CrossRef]

46. Utzinger, J.; Shuhua, X.; N'Goran, E.K.; Bergquist, R.; Tanner, M. The potential of artemether for the control of schistosomiasis. Int. J. Parasitol. 2001, 31, 1549-1562. [CrossRef]

47. Utzinger, J.; Xiao, S.; Keiser, J.; Chen, M.; Zheng, J.; Tanner, M. Current progress in the development and use of artemether for chemoprophylaxis of major human schistosome parasites. Curr. Med. Chem. 2001, 8, 1841-1860. [CrossRef] [PubMed]

48. Keiser, J.; Utzinger, J. Food-borne trematodiasis: Current chemotherapy and advances with artemisinins and synthetic trioxolanes. Trends Parasitol. 2007, 23, 555-562. [CrossRef] [PubMed]

49. Efferth, T.; Romero, M.R.; Wolf, D.G.; Stamminger, T.; Marin, J.J.G.; Marschall, M. The antiviral activities of artemisinin and artesunate. Clin. Infect. Dis. 2008, 47, 804-811. [CrossRef] [PubMed]

50. Muraleedharan, K.M.; Avery, M.A. Progress in the development of peroxide-based anti-parasitic agents. Drug Discov. Today 2009, 14, 793-803. [CrossRef] [PubMed]

51. Panic, G.; Duthaler, U.; Speich, B.; Keiser, J. Repurposing drugs for the treatment and control of helminth infections. Int. J. Parasitol. Drugs Drug Resist. 2014, 4, 185-200. [CrossRef] [PubMed]

52. Qiu, L.-P.; Chen, K.-P. Anti-hbv agents derived from botanical origin. Fitoterapia 2013, 84, 140-157. [CrossRef] [PubMed]

53. Neubig, R.R.; Spedding, M.; Kenakin, T.; Christopoulos, A. International union of pharmacology committee on receptor nomenclature and drug classification. Xxxviii. Update on terms and symbols in quantitative pharmacology. Pharmacol. Rev. 2003, 55, 597-606. [CrossRef] [PubMed]

54. Sebaugh, J.L. Guidelines for accurate ec50/ic50 estimation. Pharm. Stat. 2011, 10, 128-134. [CrossRef] [PubMed]

55. Ann Casteel, D. Peroxy natural products. Nat. Prod. Rep. 1999, 16, 55-73. [CrossRef]

56. Phillipson, D.W.; Rinehart, K.L. Antifungal peroxide-containing acids from two caribbean sponges. J. Am. Chem. Soc. 1983, 105, 7735-7736. [CrossRef]

57. Chen, Y.; Killday, K.B.; McCarthy, P.J.; Schimoler, R.; Chilson, K.; Selitrennikoff, C.; Pomponi, S.A.; Wright, A.E. Three new peroxides from the sponge plakinastrella species. J. Nat. Prod. 2001, 64, 262-264. [CrossRef] [PubMed]

58. Chen, Y.; McCarthy, P.J.; Harmody, D.K.; Schimoler-O'Rourke, R.; Chilson, K.; Selitrennikoff, C.; Pomponi, S.A.; Wright, A.E. New bioactive peroxides from marine sponges of the family plakiniidae. J. Nat. Prod. 2002, 65, 1509-1512. [CrossRef] [PubMed]

59. Oli, S.; Abdelmohsen, U.R.; Hentschel, U.; Schirmeister, T. Identification of plakortide e from the caribbean sponge plakortis halichondroides as a trypanocidal protease inhibitor using bioactivity-guided fractionation. Mar. Drugs 2014, 12, 2614-2622. [CrossRef] [PubMed] 
60. Bloodworth, A.J.; Bothwell, B.D.; Collins, A.N.; Maidwell, N.L. A short synthesis of naturally occurring and other analogues of plakinic acids that contain the 1,2-dioxolane group. Tetrahedron Lett. 1996, 37, 1885-1888. [CrossRef]

61. Dussault, P.H.; Liu, X. Lewis acid-mediated displacements of alkoxydioxolanes: Synthesis of a 1,2-dioxolane natural product. Org. Lett. 1999, 1, 1391-1393. [CrossRef] [PubMed]

62. Dai, P.; Trullinger, T.K.; Liu, X.; Dussault, P.H. Asymmetric synthesis of 1,2-dioxolane-3-acetic acids: Synthesis and configurational assignment of plakinic acid A. J. Org. Chem. 2006, 71, 2283-2292. [CrossRef] [PubMed]

63. Sun, X.-Y.; Tian, X.-Y.; Li, Z.-W.; Peng, X.-S.; Wong, H.N.C. Total synthesis of plakortide e and biomimetic synthesis of plakortone B. Chemistry 2011, 17, 5874-5880. [CrossRef] [PubMed]

64. Zhao, Q.; Wong, H.N.C. Synthetic studies toward plakortide E: Application of the feldman oxygenation to synthesis of highly substituted 1,2-dioxolanes. Tetrahedron 2007, 63, 6296-6305. [CrossRef]

65. Tian, X.-Y.; Han, J.-W.; Zhao, Q.; Wong, H.N.C. Asymmetric synthesis of 3,3,5,5-tetrasubstituted 1,2-dioxolanes: Total synthesis of epiplakinic acid f. Org. Biomol. Chem. 2014, 12, 3686-3700. [CrossRef] [PubMed]

66. Barnych, B.; Fenet, B.; Vatèle, J.-M. Asymmetric synthesis of andavadoic acid via base-catalyzed 5-exo-tet cyclization of a $\beta$-hydroperoxy epoxide. Tetrahedron 2013, 69, 334-340. [CrossRef]

67. Scott, J.J.; Oh, D.-C.; Yuceer, M.C.; Klepzig, K.D.; Clardy, J.; Currie, C.R. Bacterial protection of beetle-fungus mutualism. Science 2008, 322, 63. [CrossRef] [PubMed]

68. Oh, D.-C.; Scott, J.J.; Currie, C.R.; Clardy, J. Mycangimycin, a polyene peroxide from a mutualist streptomyces sp. Org. Lett. 2009, 11, 633-636. [CrossRef] [PubMed]

69. Nguyen, T.L.; Ferrié, L.; Figadère, B. Synthesis of 3,5-disubstituted-1,2-dioxolanes: Access to analogues of mycangimycin and some rearrangement products. Tetrahedron Lett. 2016, 57, 5286-5289. [CrossRef]

70. Qu, J.-B.; Zhu, R.-L.; Zhang, Y.-L.; Guo, H.-F.; Wang, X.-N.; Xie, C.-F.; Yu, W.-T.; Ji, M.; Lou, H.-X. Ent-kaurane diterpenoids from the liverwort jungermannia atrobrunnea. J. Nat. Prod. 2008, 71, 1418-1422. [CrossRef] [PubMed]

71. Wu, H.-H.; Chen, Y.-P.; Ying, S.-S.; Zhang, P.; Xu, Y.-T.; Gao, X.-M.; Zhu, Y. Dinardokanshones A and B, two unique sesquiterpene dimers from the roots and rhizomes of nardostachys chinensis. Tetrahedron Lett. 2015, 56, 5851-5854. [CrossRef]

72. Ingram, K.; Schiaffo, C.E.; Sittiwong, W.; Benner, E.; Dussault, P.H.; Keiser, J. In vitro and in vivo activity of 3-alkoxy-1,2-dioxolanes against schistosoma mansoni. J. Antimicrob. Chemother. 2012, 67, 1979-1986. [CrossRef] [PubMed]

73. Schiaffo, C.E.; Rottman, M.; Wittlin, S.; Dussault, P.H. 3-Alkoxy-1,2-dioxolanes: Synthesis and evaluation as potential antimalarial agents. ACS Med. Chem. Lett. 2011, 2, 316-319. [CrossRef] [PubMed]

74. Ingram, K.; Yaremenko, I.A.; Krylov, I.B.; Hofer, L.; Terent'ev, A.O.; Keiser, J. Identification of antischistosomal leads by evaluating bridged 1,2,4,5-tetraoxanes, alphaperoxides, and tricyclic monoperoxides. J. Med. Chem. 2012, 55, 8700-8711. [CrossRef] [PubMed]

75. Terent'ev, A.O.; Yaremenko, I.A.; Chernyshev, V.V.; Dembitsky, V.M.; Nikishin, G.I. Selective synthesis of cyclic peroxides from triketones and $\mathrm{H}_{2} \mathrm{O}_{2}$. J. Org. Chem. 2012, 77, 1833-1842. [CrossRef] [PubMed]

76. Terent'ev, A.O.; Yaremenko, I.A.; Vil', V.A.; Dembitsky, V.M.; Nikishin, G.I. Boron trifluoride as an efficient catalyst for the selective synthesis of tricyclic monoperoxides from $\beta, \delta$-triketones and $\mathrm{H}_{2} \mathrm{O}_{2}$. Synthesis 2013, 45, 246-250. [CrossRef]

77. Keiser, J.; Utzinger, J.; Tanner, M.; Dong, Y.; Vennerstrom, J.L. The synthetic peroxide OZ78 is effective against echinostoma caproni and fasciola hepatica. J. Antimicrob. Chemother. 2006, 58, 1193-1197. [CrossRef] [PubMed]

78. Keiser, J.; Utzinger, J.; Vennerstrom, J.L.; Dong, Y.; Brennan, G.; Fairweather, I. Activity of artemether and OZ78 against triclabendazole-resistant fasciola hepatica. Trans. R. Soc. Trop. Med. Hyg. 2007, 101, 1219-1222. [CrossRef] [PubMed]

79. Keiser, J.; Kirchhofer, C.; Haschke, M.; Huwyler, J.; Dong, Y.; Vennerstrom, J.L.; Vanhoff, K.; Kaminsky, R.; Malikides, N. Efficacy, safety and pharmacokinetics of 1,2,4-trioxolane OZ78 against an experimental infection with fasciola hepatica in sheep. Vet. Parasitol. 2010, 173, 228-235. [CrossRef] [PubMed]

80. Meister, I.; Duthaler, U.; Huwyler, J.; Rinaldi, L.; Bosco, A.; Cringoli, G.; Keiser, J. Efficacy and pharmacokinetics of OZ78 and MT04 against a natural infection with fasciola hepatica in sheep. Vet. Parasitol. 2013, 198, 102-110. [CrossRef] [PubMed] 
81. Zhao, Q.; Vargas, M.; Dong, Y.; Zhou, L.; Wang, X.; Sriraghavan, K.; Keiser, J.; Vennerstrom, J.L. Structure-activity relationship of an ozonide carboxylic acid (OZ78) against fasciola hepatica. J. Med. Chem. 2010, 53, 4223-4233. [CrossRef] [PubMed]

82. Xiao, S.-H.; Keiser, J.; Chollet, J.; Utzinger, J.; Dong, Y.; Endriss, Y.; Vennerstrom, J.L.; Tanner, M. In vitro and in vivo activities of synthetic trioxolanes against major human schistosome species. Antimicrob. Agents Chemother. 2007, 51, 1440-1445. [CrossRef] [PubMed]

83. Xiao, S.-H.; Mei, J.-Y.; Jiao, P.-Y. Schistosoma japonicum-infected hamsters (mesocricetus auratus) used as a model in experimental chemotherapy with praziquantel, artemether, and OZ compounds. Parasitol. Res. 2011, 108, 431-437. [CrossRef] [PubMed]

84. Xiao, S.-H.; Xue, J.; Mei, J.-Y.; Jiao, P.-Y. Effectiveness of synthetic trioxolane OZ78 against schistosoma japonicum in mice and rabbits. Parasitol. Res. 2012, 110, 2307-2314. [CrossRef] [PubMed]

85. Keiser, J.; Ingram, K.; Vargas, M.; Chollet, J.; Wang, X.; Dong, Y.; Vennerstrom, J.L. In vivo activity of aryl ozonides against schistosoma species. Antimicrob. Agents Chemother. 2012, 56, 1090-1092. [CrossRef] [PubMed]

86. Griesbaum, K.; Övez, B.; Huh, T.S.; Dong, Y. Ozonolyses of o-methyloximes in the presence of acid derivatives: A new access to substituted ozonides. Liebigs Ann. 1995, 1995, 1571-1574. [CrossRef]

87. Griesbaum, K.; Liu, X.; Kassiaris, A.; Scherer, M. Ozonolyses of o-alkylated ketoximes in the presence of carbonyl groups: A facile access to ozonides. Liebigs Ann. 1997, 1997, 1381-1390. [CrossRef]

88. Tang, Y.; Dong, Y.; Karle, J.M.; DiTusa, C.A.; Vennerstrom, J.L. Synthesis of tetrasubstituted ozonides by the griesbaum coozonolysis reaction: Diastereoselectivity and functional group transformations by post-ozonolysis reactions. J. Org. Chem. 2004, 69, 6470-6473. [CrossRef] [PubMed]

89. Dong, Y.; Chollet, J.; Matile, H.; Charman, S.A.; Chiu, F.C.K.; Charman, W.N.; Scorneaux, B.; Urwyler, H.; Santo Tomas, J.; Scheurer, C.; et al. Spiro and dispiro-1,2,4-trioxolanes as antimalarial peroxides: Charting a workable structure-activity relationship using simple prototypes. J. Med. Chem. 2005, 48, 4953-4961. [CrossRef] [PubMed]

90. Manzo, E.; Ciavatta, M.L.; Melck, D.; Schupp, P.; de Voogd, N.; Gavagnin, M. Aromatic cyclic peroxides and related keto-compounds from the plakortis sp. Component of a sponge consortium. J. Nat. Prod. 2009, 72, 1547-1551. [CrossRef] [PubMed]

91. Feng, Y.; Davis, R.A.; Sykes, M.; Avery, V.M.; Camp, D.; Quinn, R.J. Antitrypanosomal cyclic polyketide peroxides from the australian marine sponge plakortis sp. J. Nat. Prod. 2010, 73, 716-719. [CrossRef] [PubMed]

92. Jamison, M.T.; Dalisay, D.S.; Molinski, T.F. Peroxide natural products from plakortis zyggompha and the sponge association plakortis halichondrioides-xestospongia deweerdtae: Antifungal activity against cryptococcus gattii. J. Nat. Prod. 2016, 79, 555-563. [CrossRef] [PubMed]

93. Kobayashi, M.; Kondo, K.; Kitagawa, I. Antifungal peroxyketal acids from an okinawan marine sponge of plakortis sp. Chem. Pharm. Bull. 1993, 41, 1324-1326. [CrossRef] [PubMed]

94. Rubio, B.K.; Tenney, K.; Ang, K.-H.; Abdulla, M.; Arkin, M.; McKerrow, J.H.; Crews, P. The marine sponge diacarnus bismarckensis as a source of peroxiterpene inhibitors of trypanosoma brucei, the causative agent of sleeping sickness. J. Nat. Prod. 2009, 72, 218-222. [CrossRef] [PubMed]

95. Kashman, Y.; Rotem, M. Muqubilin, a new c24-isoprenoid from a marine sponge. Tetrahedron Lett. 1979, 20, 1707-1708. [CrossRef]

96. El Sayed, K.A.; Hamann, M.T.; Hashish, N.E.; Shier, W.T.; Kelly, M.; Khan, A.A. Antimalarial, antiviral, and antitoxoplasmosis norsesterterpene peroxide acids from the red sea sponge diacarnus erythraeanus. J. Nat. Prod. 2001, 64, 522-524. [CrossRef] [PubMed]

97. Peng, J.; Shen, X.; El Sayed, K.A.; Dunbar, D.C.; Perry, T.L.; Wilkins, S.P.; Hamann, M.T.; Bobzin, S.; Huesing, J.; Camp, R.; et al. Marine natural products as prototype agrochemical agents. J. Agric. Food Chem. 2003, 51, 2246-2252. [CrossRef] [PubMed]

98. Cheenpracha, S.; Park, E.-J.; Rostama, B.; Pezzuto, J.M.; Chang, L.C. Inhibition of nitric oxide (no) production in lipopolysaccharide (lps)-activated murine macrophage raw 264.7 cells by the norsesterterpene peroxide, epimuqubilin A. Mar. Drugs 2010, 8, 429-437. [CrossRef] [PubMed]

99. Tanaka, J.; Higa, T.; Suwanborirux, K.; Kokpol, U.; Bernardinelli, G.; Jefford, C.W. Bioactive norsesterterpene 1,2-dioxanes from a thai sponge, mycale sp. J. Org. Chem. 1993, 58, 2999-3002. [CrossRef]

100. Jung, M.; Ham, J.; Song, J. First total synthesis of natural 6-epiplakortolide e. Org. Lett. 2002, 4, $2763-2765$. [CrossRef] [PubMed] 
101. Perry, T.L.; Dickerson, A.; Khan, A.A.; Kondru, R.K.; Beratan, D.N.; Wipf, P.; Kelly, M.; Hamann, M.T. New peroxylactones from the Jamaican sponge plakinastrella onkodes, with inhibitory activity against the aids opportunistic parasitic infection toxoplasma gondii. Tetrahedron 2001, 57, 1483-1487. [CrossRef]

102. Xu, C.; Schwartz, C.; Raible, J.; Dussault, P.H. Asymmetric synthesis of 1,2-dioxanes: Approaches to the peroxyplakoric acids. Tetrahedron 2009, 65, 9680-9685. [CrossRef] [PubMed]

103. Gemma, S.; Gabellieri, E.; Sanna Coccone, S.; Martí, F.; Taglialatela-Scafati, O.; Novellino, E.; Campiani, G.; Butini, S. Synthesis of dihydroplakortin, 6-epi-dihydroplakortin, and their c10-desethyl analogues. J. Org. Chem. 2010, 75, 2333-2340. [CrossRef] [PubMed]

104. Barnych, B.; Vatèle, J.-M. Total synthesis of seco-plakortolide E and (-)-ent-plakortolide I: Absolute configurational revision of natural plakortolide I. Org. Lett. 2012, 14, 564-567. [CrossRef] [PubMed]

105. Holla, H.; Labaied, M.; Pham, N.; Jenkins, I.D.; Stuart, K.; Quinn, R.J. Synthesis of antitrypanosomal 1,2-dioxane derivatives based on a natural product scaffold. Bioorg. Med. Chem. Lett. 2011, 21, 4793-4797. [CrossRef] [PubMed]

106. Silva, E.M.P.; Pye, R.J.; Brown, G.D.; Harwood, L.M. Towards the total synthesis of mycaperoxide b: Probing biosynthetic rationale. Eur. J. Org. Chem. 2012, 2012, 1209-1216. [CrossRef]

107. Kiuchi, F.; Itano, Y.; Uchiyama, N.; Honda, G.; Tsubouchi, A.; Nakajima-Shimada, J.; Aoki, T. Monoterpene hydroperoxides with trypanocidal activity from chenopodium ambrosioides. J. Nat. Prod. 2002, 65, 509-512. [CrossRef] [PubMed]

108. Monzote, L.; Montalvo, A.M.; Almanonni, S.; Scull, R.; Miranda, M.; Abreu, J. Activity of the essential oil from Chenopodium ambrosioides grown in Cuba against Leishmania amazonensis. Chemotherapy 2006, 52, 130-136. [CrossRef] [PubMed]

109. Wallach, O. Zur kenntnis der terpene und der ätherischen öle. Justus Liebigs Ann. Chem. 1912, 392, 49-75. [CrossRef]

110. Nelson, E.K. The composition of oil of chenopodium from various sources. J. Am. Chem. Soc. 1920, 42, 1204-1208. [CrossRef]

111. Smillie, W.G.; Pessôa, S.B. A study of the anthelmintic properties of the constituents of the oil of chenopodium. J. Pharmacol. Exp. Ther. 1924, 24, 359-370.

112. Bodendorf, K. Über ungesättigte peroxyde. Zugleich ein beitrag zur kenntnis der autoxydationsvorgänge. Arch. Pharm. 1933, 271, 1-35. [CrossRef]

113. Beckett, A.H.; Donbrow, M.; Jolliffe, G.O. Ascaridole studies: Part iii. The purification and characterisation of ascaridole. J. Pharm. Pharmacol. 1955, 7, 55-65. [CrossRef] [PubMed]

114. Beckett, A.H.; Jolliffe, G.O. A note on the determination of ascaridole in oil of chenopodium. J. Pharm. Pharmacol. 1955, 7, 606-607. [CrossRef] [PubMed]

115. Schenck, G.O.; Ziegler, K. Die synthese des ascaridols. Naturwissenschaften 1944, 32, 157.

116. Pape, M. Industrial applications of photochemistry. Pure Appl. Chem. 1975, 41, 535-558. [CrossRef]

117. Aubry, J.-M.; Bouttemy, S. Preparative oxidation of organic compounds in microemulsions with singlet oxygen generated chemically by the sodium molybdate/hydrogen peroxide system1. J. Am. Chem. Soc. 1997, 119, 5286-5294. [CrossRef]

118. Paré, P.W.; Zajicek, J.; Ferracini, V.L.; Melo, I.S. Antifungal terpenoids from chenopodium ambrosioides. Biochem. Syst. Ecol. 1993, 21, 649-653. [CrossRef]

119. MacDonald, D.; VanCrey, K.; Harrison, P.; Rangachari, P.K.; Rosenfeld, J.; Warren, C.; Sorger, G. Ascaridole-less infusions of chenopodium ambrosioides contain a nematocide(s) that is(are) not toxic to mammalian smooth muscle. J. Ethnopharmacol. 2004, 92, 215-221. [CrossRef] [PubMed]

120. Gunasekera, S.P.; Gunasekera, M.; Gunawardana, G.P.; McCarthy, P.; Burres, N. Two new bioactive cyclic peroxides from the marine sponge plakortis angulospiculatus. J. Nat. Prod. 1990, 53, 669-674. [CrossRef]

121. Yao, G.; Steliou, K. Synthetic studies toward bioactive cyclic peroxides from the marine sponge plakortis angulospiculatus. Org. Lett. 2002, 4, 485-488. [CrossRef] [PubMed]

122. Yu, D.-Q.; Chen, R.-Y.; Huang, L.-J.; Xie, F.-Z.; Ming, D.-S.; Zhou, K.; Li, H.-Y.; Tong, K.-M. The structure and absolute configuration of shuangkangsu: A novel natural cyclic peroxide from Lonicera japonica (Thunb.). J. Asian Nat. Prod. Res. 2008, 10, 851-856. [CrossRef] [PubMed]

123. Dias, D.A.; Urban, S. HPLC and NMR studies of phenoxazone alkaloids from pycnoporus cinnabarinus. Nat. Prod. Commun. 2009, 4, 489-498. [PubMed] 
124. Wang, F.-W. Bioactive metabolites from Guignardia sp., an endophytic fungus residing in undaria pinnatifida. Chin. J. Nat. Med. 2012, 10, 72-76. [CrossRef] [PubMed]

125. Barton, D.H.R.; Leclerc, G.; Magnus, P.D.; Menzies, I.D. An unusual synthesis of ergosterol acetate peroxide. J. Chem. Soc. Chem. Commun. 1972, 447-449. [CrossRef]

126. Jia, M.; Zhao, R.; Xu, B.; Yan, W.; Chu, F.; Gu, H.; Xie, T.; Xiang, H.; Ren, J.; Chen, D.; et al. Synthesis and biological activity evaluation of novel peroxo-bridged derivatives as potential anti-hepatitis $\mathrm{b}$ virus agents. Med. Chem. Comm. 2017, 8, 148-151. [CrossRef]

127. Macreadie, P.; Avery, T.; Greatrex, B.; Taylor, D.; Macreadie, I. Novel endoperoxides: Synthesis and activity against candida species. Bioorg. Med. Chem. Lett. 2006, 16, 920-922. [CrossRef] [PubMed]

128. Avery, T.D.; Macreadie, P.I.; Greatrex, B.W.; Robinson, T.V.; Taylor, D.K.; Macreadie, I.G. Design of endoperoxides with anti-candida activity. Bioorg. Med. Chem. 2007, 15, 36-42. [CrossRef] [PubMed]

129. Macreadie, I.G.; Avery, T.D.; Robinson, T.V.; Macreadie, P.; Barraclough, M.; Taylor, D.K.; Tiekink, E.R.T. Design of 1,2-dioxines with anti-candida activity: Aromatic substituted 1,2-dioxines. Tetrahedron 2008, 64, 1225-1232. [CrossRef]

130. Vil', V.; Yaremenko, I.; Ilovaisky, A.; Terent'ev, A. Synthetic strategies for peroxide ring construction in artemisinin. Molecules 2017, 22, 117. [CrossRef] [PubMed]

131. Kopetzki, D.; Lévesque, F.; Seeberger, P.H. A continuous-flow process for the synthesis of artemisinin. Chemistry 2013, 19, 5450-5456. [CrossRef] [PubMed]

132. Vonwiller, S.C.; Warner, J.A.; Mann, S.T.; Haynes, R.K. Copper(ii) trifluoromethanesulfonate-induced cleavage oxygenation of allylic hydroperoxides derived from qinghao acid in the synthesis of qinghaosu derivatives: Evidence for the intermediacy of enols. J. Am. Chem. Soc. 1995, 117, 11098-11105. [CrossRef]

133. Yang, D.M.; Liew, F.Y. Effects of qinghaosu (artemisinin) and its derivatives on experimental cutaneous leishmaniasis. Parasitology 1993, 106, 7-11. [CrossRef] [PubMed]

134. Sen, R.; Bandyopadhyay, S.; Dutta, A.; Mandal, G.; Ganguly, S.; Saha, P.; Chatterjee, M. Artemisinin triggers induction of cell-cycle arrest and apoptosis in leishmania donovani promastigotes. J. Med. Microbiol. 2007, 56, 1213-1218. [CrossRef] [PubMed]

135. Mishina, Y.V.; Krishna, S.; Haynes, R.K.; Meade, J.C. Artemisinins inhibit trypanosoma cruzi and trypanosoma brucei rhodesiense in vitro growth. Antimicrob. Agents Chemother. 2007, 51, 1852-1854. [CrossRef] [PubMed]

136. Ke, O.Y.; Krug, E.C.; Marr, J.J.; Berens, R.L. Inhibition of growth of toxoplasma gondii by qinghaosu and derivatives. Antimicrob. Agents Chemother. 1990, 34, 1961-1965. [CrossRef] [PubMed]

137. Gautam, P.; Upadhyay, S.K.; Hassan, W.; Madan, T.; Sirdeshmukh, R.; Sundaram, C.S.; Gade, W.N.; Basir, S.F.; Singh, Y.; Sarma, P.U. Transcriptomic and proteomic profile of aspergillus fumigatus on exposure to artemisinin. Mycopathologia 2011, 172, 331. [CrossRef] [PubMed]

138. Buragohain, P.; Surineni, N.; Barua, N.C.; Bhuyan, P.D.; Boruah, P.; Borah, J.C.; Laisharm, S.; Moirangthem, D.S. Synthesis of a novel series of fluoroarene derivatives of artemisinin as potent antifungal and anticancer agent. Bioorg. Med. Chem. Lett. 2015, 25, 3338-3341. [CrossRef] [PubMed]

139. Oguariri, R.M.; Adelsberger, J.W.; Baseler, M.W.; Imamichi, T. Evaluation of the effect of pyrimethamine, an anti-malarial drug, on hiv-1 replication. Virus Res. 2010, 153, 269-276. [CrossRef] [PubMed]

140. Paeshuyse, J.; Coelmont, L.; Vliegen, I.; Hemel, J.V.; Vandenkerckhove, J.; Peys, E.; Sas, B.; Clercq, E.D.; Neyts, J. Hemin potentiates the anti-hepatitis c virus activity of the antimalarial drug artemisinin. Biochem. Biophys. Res. Commun. 2006, 348, 139-144. [CrossRef] [PubMed]

141. Romero, M.R.; Serrano, M.A.; Vallejo, M.; Efferth, T.; Alvarez, M.; Marin, J.J.G. Antiviral effect of artemisinin from artemisia annua against a model member of the flaviviridae family, the bovine viral diarrhoea virus (BVDV). Planta Med. 2006, 72, 1169-1174. [CrossRef] [PubMed]

142. Parvez, M.K.; Arbab, A.H.; Al-Dosari, M.S.; Al-Rehaily, A.J. Antiviral natural products against chronic hepatitis b: Recent developments. Curr. Pharm. Des. 2016, 22, 286-293. [CrossRef] [PubMed]

143. Li, Y.-S.; Chen, H.-G.; He, H.-B.; Hou, X.-Y.; Ellis, M.; McManus, D.P. A double-blind field trial on the effects of artemether on schistosoma japonicum infection in a highly endemic focus in southern china. Acta Trop. 2005, 96, 184-190. [CrossRef] [PubMed]

144. O'Neill, J.F.; Johnston, R.C.; Halferty, L.; Hanna, R.E.B.; Brennan, G.P.; Fairweather, I. A comparative study on the impact of two artemisinin derivatives, artemether and artesunate, on the female reproductive system of fasciola hepatica. Vet. Parasitol. 2015, 211, 182-194. [CrossRef] [PubMed] 
145. O’Neill, J.F.; Johnston, R.C.; Halferty, L.; Hanna, R.E.B.; Brennan, G.P.; Fairweather, I. Disruption of spermatogenesis in the liver fluke, fasciola hepatica by two artemisinin derivatives, artemether and artesunate. J. Helminthol. 2017, 91, 55-71. [CrossRef] [PubMed]

146. Keiser, J.; Sayed, H.; El-Ghanam, M.; Sabry, H.; Anani, S.; El-Wakeel, A.; Hatz, C.; Utzinger, J.; El-Din, S.S.; El-Maadawy, W.; et al. Efficacy and safety of artemether in the treatment of chronic fascioliasis in egypt: Exploratory phase-2 trials. PLoS Negl. Trop. Dis. 2011, 5, e1285. [CrossRef] [PubMed]

147. Jones-Brando, L.; D’Angelo, J.; Posner, G.H.; Yolken, R. In vitro inhibition of toxoplasma gondii by four new derivatives of artemisinin. Antimicrob. Agents Chemother. 2006, 50, 4206-4208. [CrossRef] [PubMed]

148. Cuzzocrea, S.; Saadat, F.; Di Paola, R.; Mirshafiey, A. Artemether: A new therapeutic strategy in experimental rheumatoid arthritis. Immunopharmacol. Immunotoxicol. 2005, 27, 615-630. [CrossRef] [PubMed]

149. Wang, J.X.; Tang, W.; Shi, L.P.; Wan, J.; Zhou, R.; Ni, J.; Fu, Y.F.; Yang, Y.F.; Li, Y.; Zuo, J.P. Investigation of the immunosuppressive activity of artemether on t-cell activation and proliferation. Br. J. Pharmacol. 2007, 150, 652-661. [CrossRef] [PubMed]

150. Haynes, R.K.; Vonwiller, S.C. Extraction of artemisinin and artemisinic acid: Preparation of artemether and new analogues. Trans. R. Soc. Trop. Med. Hyg. 1994, 88, 23-26. [CrossRef]

151. Stringham, R.W.; Teager, D.S. Streamlined process for the conversion of artemisinin to artemether. Org. Process Res. Dev. 2012, 16, 764-768. [CrossRef]

152. Gilmore, K.; Kopetzki, D.; Lee, J.W.; Horvath, Z.; McQuade, D.T.; Seidel-Morgenstern, A.; Seeberger, P.H. Continuous synthesis of artemisinin-derived medicines. Chem. Commun. 2014, 50, 12652-12655. [CrossRef] [PubMed]

153. Yaseneva, P.; Plaza, D.; Fan, X.; Loponov, K.; Lapkin, A. Synthesis of the antimalarial API artemether in a flow reactor. Catal. Today 2015, 239, 90-96. [CrossRef]

154. Li, S.; Wu, L.; Liu, Z.; Hu, L.; Xu, P.; Xuan, Y.; Liu, Y.; Liu, X.; Fan, J. Studies on prophylactic effect of artesunate on schistosomiasis japonica. Chin. Med. J. 1996, 109, 848-853. [PubMed]

155. Liu, R.; Dong, H.-F.; Guo, Y.; Zhao, Q.-P.; Jiang, M.-S. Efficacy of praziquantel and artemisinin derivatives for the treatment and prevention of human schistosomiasis: A systematic review and meta-analysis. Parasites Vectors 2011, 4, 201. [CrossRef] [PubMed]

156. Hien, T.T.; Truong, N.T.; Minh, N.H.; Dat, H.D.; Dung, N.T.; Hue, N.T.; Dung, T.K.; Tuan, P.Q.; Campbell, J.I.; Farrar, J.J.; et al. A randomized controlled pilot study of artesunate versus triclabendazole for human fascioliasis in central Vietnam. Am. J. Trop. Med. Hyg. 2008, 78, 388-392. [PubMed]

157. Romero, M.R.; Efferth, T.; Serrano, M.A.; Castaño, B.; Macias, R.I.R.; Briz, O.; Marin, J.J.G. Effect of artemisinin/artesunate as inhibitors of hepatitis b virus production in an "in vitro" replicative system. Antivir. Res. 2005, 68, 75-83. [CrossRef] [PubMed]

158. Dai, R.; Xiao, X.; Peng, F.; Li, M.; Gong, G. Artesunate, an anti-malarial drug, has a potential to inhibit hcv replication. Virus Genes 2016, 52, 22-28. [CrossRef] [PubMed]

159. Milbradt, J.; Auerochs, S.; Korn, K.; Marschall, M. Sensitivity of human herpesvirus 6 and other human herpesviruses to the broad-spectrum antiinfective drug artesunate. J. Clin. Virol. 2009, 46, 24-28. [CrossRef] [PubMed]

160. Hakacova, N.; Klingel, K.; Kandolf, R.; Engdahl, E.; Fogdell-Hahn, A.; Higgins, T. First therapeutic use of artesunate in treatment of human herpesvirus $6 \mathrm{~b}$ myocarditis in a child. J. Clin. Virol. 2013, 57, 157-160. [CrossRef] [PubMed]

161. Efferth, T.; Marschall, M.; Wang, X.; Huong, S.-M.; Hauber, I.; Olbrich, A.; Kronschnabl, M.; Stamminger, T.; Huang, E.-S. Antiviral activity of artesunate towards wild-type, recombinant, and ganciclovir-resistant human cytomegaloviruses. J. Mol. Med. 2002, 80, 233-242. [CrossRef] [PubMed]

162. Flobinus, A.; Taudon, N.; Desbordes, M.; Labrosse, B.; Simon, F.; Mazeron, M.-C.; Schnepf, N. Stability and antiviral activity against human cytomegalovirus of artemisinin derivatives. J. Antimicrob. Chemother. 2014, 69, 34-40. [CrossRef] [PubMed]

163. Zeng, A.-H.; Ou, Y.-Y.; Guo, M.-M.; Dai, X.; Zhou, D.-Z.; Chen, R. Human embryonic lung fibroblasts treated with artesunate exhibit reduced rates of proliferation and human cytomegalovirus infection in vitro. J. Thorac. Dis. 2015, 7, 1151-1157. [PubMed]

164. Chou, S.; Marousek, G.; Auerochs, S.; Stamminger, T.; Milbradt, J.; Marschall, M. The unique antiviral activity of artesunate is broadly effective against human cytomegaloviruses including therapy-resistant mutants. Antivir. Res. 2011, 92, 364-368. [CrossRef] [PubMed] 
165. Menon, R.B.; Kannoth, M.M.; Tekwani, B.L.; Gut, J.; Rosenthal, P.J.; Avery, M.A. A new library of c-16 modified artemisinin analogs and evaluation of their anti-parasitic activities. Combinatorial Chem. High Throughput Screen. 2006, 9, 729-741. [CrossRef]

166. D'Angelo, J.G.; Bordón, C.; Posner, G.H.; Yolken, R.; Jones-Brando, L. Artemisinin derivatives inhibit toxoplasma gondii in vitro at multiple steps in the lytic cycle. J. Antimicrob. Chemother. 2009, 63, 146-150. [CrossRef] [PubMed]

167. Galal, A.M.; Ross, S.A.; Jacob, M.; ElSohly, M.A. Antifungal activity of artemisinin derivatives. J. Nat. Prod. 2005, 68, 1274-1276. [CrossRef] [PubMed]

168. Lin, A.J.; Lee, M.; Klayman, D.L. Antimalarial activity of new water-soluble dihydroartemisinin derivatives. 2. Stereospecificity of the ether side chain. J. Med. Chem. 1989, 32, 1249-1252. [CrossRef] [PubMed]

169. Brossi, A.; Venugopalan, B.; Dominguez Gerpe, L.; Yeh, H.J.C.; Flippen-Anderson, J.L.; Buchs, P.; Luo, X.D.; Milhous, W.; Peters, W. Arteether, a new antimalarial drug: Synthesis and antimalarial properties. J. Med. Chem. 1988, 31, 645-650. [CrossRef] [PubMed]

170. Jung, M.; Schinazi, R.F. Synthesis and in vitro anti-human immunodeficiency virus activity of artemisinin (qinghaosu)-related trioxanes. Bioorg. Med. Chem. Lett. 1994, 4, 931-934. [CrossRef]

171. Blazquez, A.G.; Fernandez-Dolon, M.; Sanchez-Vicente, L.; Maestre, A.D.; Gomez-San Miguel, A.B.; Alvarez, M.; Serrano, M.A.; Jansen, H.; Efferth, T.; Marin, J.J.G.; et al. Novel artemisinin derivatives with potential usefulness against liver/colon cancer and viral hepatitis. Bioorg. Med. Chem. 2013, 21, 4432-4441. [CrossRef] [PubMed]

172. Jung, M.; Bustos, D.A.; ElSohly, H.N.; McChesney, J.D. A concise and stereoselective synthesis of (+)-12-n-butyldeoxoartemisinin. Synlett 1990, 1990, 743-744. [CrossRef]

173. Aminake, M.N.; Mahajan, A.; Kumar, V.; Hans, R.; Wiesner, L.; Taylor, D.; de Kock, C.; Grobler, A.; Smith, P.J.; Kirschner, M.; et al. Synthesis and evaluation of hybrid drugs for a potential HIV / AIDS-malaria combination therapy. Bioorg. Med. Chem. 2012, 20, 5277-5289. [CrossRef] [PubMed]

174. Slade, D.; Galal, A.M.; Gul, W.; Radwan, M.M.; Ahmed, S.A.; Khan, S.I.; Tekwani, B.L.; Jacob, M.R.; Ross, S.A.; ElSohly, M.A. Antiprotozoal, anticancer and antimicrobial activities of dihydroartemisinin acetal dimers and monomers. Bioorg. Med. Chem. 2009, 17, 7949-7957. [CrossRef] [PubMed]

175. Posner, G.H.; Paik, I.-H.; Sur, S.; McRiner, A.J.; Borstnik, K.; Xie, S.; Shapiro, T.A. Orally active, antimalarial, anticancer, artemisinin-derived trioxane dimers with high stability and efficacy. J. Med. Chem. 2003, 46, 1060-1065. [CrossRef] [PubMed]

176. Arav-Boger, R.; He, R.; Chiou, C.-J.; Liu, J.; Woodard, L.; Rosenthal, A.; Jones-Brando, L.; Forman, M.; Posner, G. Artemisinin-derived dimers have greatly improved anti-cytomegalovirus activity compared to artemisinin monomers. PLoS ONE 2010, 5, e10370. [CrossRef] [PubMed]

177. Roy, S.; He, R.; Kapoor, A.; Forman, M.; Mazzone, J.R.; Posner, G.H.; Arav-Boger, R. Inhibition of human cytomegalovirus replication by artemisinins: Effects mediated through cell cycle modulation. Antimicrob. Agents Chemother. 2015, 59, 3870-3879. [CrossRef] [PubMed]

178. Rosenthal, A.S.; Chen, X.; Liu, J.O.; West, D.C.; Hergenrother, P.J.; Shapiro, T.A.; Posner, G.H. Malaria-infected mice are cured by a single oral dose of new dimeric trioxane sulfones which are also selectively and powerfully cytotoxic to cancer cells. J. Med. Chem. 2009, 52, 1198-1203. [CrossRef] [PubMed]

179. Alagbala, A.A.; McRiner, A.J.; Borstnik, K.; Labonte, T.; Chang, W.; D’Angelo, J.G.; Posner, G.H.; Foster, B.A. Biological mechanisms of action of novel c-10 non-acetal trioxane dimers in prostate cancer cell lines. J. Med. Chem. 2006, 49, 7836-7842. [CrossRef] [PubMed]

180. He, R.; Mott, B.T.; Rosenthal, A.S.; Genna, D.T.; Posner, G.H.; Arav-Boger, R. An artemisinin-derived dimer has highly potent anti-cytomegalovirus (CMV) and anti-cancer activities. PLoS ONE 2011, 6, e24334. [CrossRef] [PubMed]

181. He, R.; Park, K.; Cai, H.; Kapoor, A.; Forman, M.; Mott, B.; Posner, G.H.; Arav-Boger, R. Artemisinin-derived dimer diphenyl phosphate is an irreversible inhibitor of human cytomegalovirus replication. Antimicrob. Agents Chemother. 2012, 56, 3508-3515. [CrossRef] [PubMed]

182. He, R.; Forman, M.; Mott, B.T.; Venkatadri, R.; Posner, G.H.; Arav-Boger, R. Unique and highly selective anticytomegalovirus activities of artemisinin-derived dimer diphenyl phosphate stem from combination of dimer unit and a diphenyl phosphate moiety. Antimicrob. Agents Chemother. 2013, 57, 4208-4214. [CrossRef] [PubMed] 
183. Mott, B.T.; He, R.; Chen, X.; Fox, J.M.; Civin, C.I.; Arav-Boger, R.; Posner, G.H. Artemisinin-derived dimer phosphate esters as potent anti-cytomegalovirus (anti-cmv) and anti-cancer agents: A structure-activity study. Bioorg. Med. Chem. 2013, 21, 3702-3707. [CrossRef] [PubMed]

184. Reiter, C.; Fröhlich, T.; Gruber, L.; Hutterer, C.; Marschall, M.; Voigtländer, C.; Friedrich, O.; Kappes, B.; Efferth, T.; Tsogoeva, S.B. Highly potent artemisinin-derived dimers and trimers: Synthesis and evaluation of their antimalarial, antileukemia and antiviral activities. Bioorg. Med. Chem. 2015, 23, 5452-5458. [CrossRef] [PubMed]

185. Hutterer, C.; Niemann, I.; Milbradt, J.; Fröhlich, T.; Reiter, C.; Kadioglu, O.; Bahsi, H.; Zeitträger, I.; Wagner, S.; Einsiedel, J.; et al. The broad-spectrum antiinfective drug artesunate interferes with the canonical nuclear factor kappa b (Nf-kB) pathway by targeting RelA/p65. Antivir. Res. 2015, 124, 101-109. [CrossRef] [PubMed]

186. Reiter, C.; Fröhlich, T.; Zeino, M.; Marschall, M.; Bahsi, H.; Leidenberger, M.; Friedrich, O.; Kappes, B.; Hampel, F.; Efferth, T.; et al. New efficient artemisinin derived agents against human leukemia cells, human cytomegalovirus and plasmodium falciparum: 2nd generation 1,2,4-trioxane-ferrocene hybrids. Eur. J. Med. Chem. 2015, 97, 164-172. [CrossRef] [PubMed]

187. Obeid, S.; Alen, J.; Nguyen, V.H.; Pham, V.C.; Meuleman, P.; Pannecouque, C.; Le, T.N.; Neyts, J.; Dehaen, W.; Paeshuyse, J. Artemisinin analogues as potent inhibitors of in vitro hepatitis c virus replication. PLoS ONE 2013, 8, e81783. [CrossRef] [PubMed]

188. Wang, X.; Zhao, Q.; Vargas, M.; Dong, Y.; Sriraghavan, K.; Keiser, J.; Vennerstrom, J.L. The activity of dispiro peroxides against fasciola hepatica. Bioorg. Med. Chem. Lett. 2011, 21, 5320-5323. [CrossRef] [PubMed]

189. Amewu, R.; Stachulski, A.V.; Ward, S.A.; Berry, N.G.; Bray, P.G.; Davies, J.; Labat, G.; Vivas, L.; O’Neill, P.M. Design and synthesis of orally active dispiro 1,2,4,5-tetraoxanes; synthetic antimalarials with superior activity to artemisinin. Organ. Biomol. Chem. 2006, 4, 4431-4436. [CrossRef] [PubMed]

190. Duan, W.-W.; Qiu, S.-J.; Zhao, Y.; Sun, H.; Qiao, C.; Xia, C.-M. Praziquantel derivatives exhibit activity against both juvenile and adult schistosoma japonicum. Bioorg. Med. Chem. Lett. 2012, 22, 1587-1590. [CrossRef] [PubMed]

191. Yang, J.-J.; Boissier, J.; Chen, J.-L.; Yao, H.; Yang, S.; Rognon, A.; Qiao, C. Design, synthesis and biological evaluation of praziquantel and endoperoxide conjugates as antischistosomal agents. Future Med. Chem. 2015, 7, 713-725. [CrossRef] [PubMed]

192. Cowan, N.; Yaremenko, I.A.; Krylov, I.B.; Terent'ev, A.O.; Keiser, J. Elucidation of the in vitro and in vivo activities of bridged 1,2,4-trioxolanes, bridged 1,2,4,5-tetraoxanes, tricyclic monoperoxides, silyl peroxides, and hydroxylamine derivatives against schistosoma mansoni. Bioorg. Med. Chem. 2015, 23, 5175-5181. [CrossRef] [PubMed]

193. Terent'ev, A.O.; Borisov, D.A.; Chernyshev, V.V.; Nikishin, G.I. Facile and selective procedure for the synthesis of bridged 1,2,4,5-tetraoxanes; strong acids as cosolvents and catalysts for addition of hydrogen peroxide to $\beta$-diketones. J. Org. Chem. 2009, 74, 3335-3340. [CrossRef] [PubMed]

194. Terent'ev, A.O.; Yaremenko, I.A.; Vil, V.A.; Moiseev, I.K.; Kon'kov, S.A.; Dembitsky, V.M.; Levitsky, D.O.; Nikishin, G.I. Phosphomolybdic and phosphotungstic acids as efficient catalysts for the synthesis of bridged 1,2,4,5-tetraoxanes from [small beta]-diketones and hydrogen peroxide. Org. Biomol. Chem. 2013, 11, 2613-2623. [CrossRef] [PubMed]

195. Shul'pin, G.B. Metal-catalyzed hydrocarbon oxygenations in solutions: The dramatic role of additives: A review. J. Mol. Catal. A Chem. 2002, 189, 39-66. [CrossRef]

196. Wu, X.-F.; Gong, J.-L.; Qi, X. A powerful combination: Recent achievements on using tbai and tbhp as oxidation system. Org. Biomol. Chem. 2014, 12, 5807-5817. [CrossRef] [PubMed]

197. Saiz, A.I.; Manrique, G.D.; Fritz, R. Determination of benzoyl peroxide and benzoic acid levels by hplc during wheat flour bleaching process. J. Agric. Food Chem. 2001, 49, 98-102. [CrossRef] [PubMed]

198. Abe-Onishi, Y.; Yomota, C.; Sugimoto, N.; Kubota, H.; Tanamoto, K. Determination of benzoyl peroxide and benzoic acid in wheat flour by high-performance liquid chromatography and its identification by high-performance liquid chromatography-mass spectrometry. J. Chromatogr. A 2004, 1040, 209-214. [CrossRef] [PubMed]

199. Mu, G.; Liu, H.; Gao, Y.; Luan, F. Determination of benzoyl peroxide, as benzoic acid, in wheat flour by capillary electrophoresis compared with hplc. J. Sci. Food Agric. 2012, 92, 960-964. [CrossRef] [PubMed]

200. Cotterill, J.A. Benzoyl peroxide. Acta Derm.-Venereol. Suppl. 1980, (Suppl. S89), 57-63. 
201. Leyden, J.J.; Wortzman, M.; Baldwin, E.K. Antibiotic-resistant propionibacterium acnes suppressed by a benzoyl peroxide cleanser 6\%. Cutis 2008, 82, 417-421. [PubMed]

202. Burkhart, C.G.; Burkhart, C.N.; Isham, N. Synergistic antimicrobial activity by combining an allylamine with benzoyl peroxide with expanded coverage against yeast and bacterial species. Br. J. Dermatol. 2006, 154, 341-344. [CrossRef] [PubMed]

203. Hegemann, L.; Toso, S.M.; Kitay, K.; Webster, C.F. Anti-inflammatory actions of benzoyl peroxide: Effects on the generation of reactive oxygen species by leucocytes and the activity of protein kinase $\mathrm{c}$ and calmodulin. Br. J. Dermatol. 1994, 130, 569-575. [CrossRef] [PubMed]

204. Waller, J.M.; Dreher, F.; Behnam, S.; Ford, C.; Lee, C.; Tiet, T.; Weinstein, G.D.; Maibach, H.I. 'Keratolytic' properties of benzoyl peroxide and retinoic acid resemble salicylic acid in man. Skin Pharmacol. Physiol. 2006, 19, 283-289. [CrossRef] [PubMed]

205. Merker, P.C. Benzoyl peroxide: A history of early research and researchers. Int. J. Dermatol. 2002, 41, $185-188$. [CrossRef] [PubMed]

206. Alvarez, O.M.; Mertz, P.M.; Eaglstein, W.H. Benzoyl peroxide and epidermal wound healing. Arch. Dermatol. 1983, 119, 222-225. [CrossRef] [PubMed]

207. Sagransky, M.; Yentzer, B.A.; Feldman, S.R. Benzoyl peroxide: A review of its current use in the treatment of acne vulgaris. Expert Opin. Pharmacother. 2009, 10, 2555-2562. [CrossRef] [PubMed]

208. Burkhart, C.G.; Burkhart, C.N. The chemistry and synergy of benzoyl peroxide with clindamycin. Br. J. Dermatol. 2008, 159, 480-481. [CrossRef] [PubMed]

209. Kaur, J.; Sehgal, V.K.; Gupta, A.K.; Singh, S.P. A comparative study to evaluate the efficacy and safety of combination topical preparations in acne vulgaris. Int. J. Appl. Basic Med. Res. 2015, 5, 106-110. [CrossRef] [PubMed]

210. Burkhart, C.G.; Burkhart, C.N. Treatment of acne vulgaris without antibiotics: Tertiary amine-benzoyl peroxide combination vs. Benzoyl peroxide alone (proactiv solution ${ }^{\mathrm{TM}}$ ). Int. J. Dermatol. 2007, 46, 89-93. [CrossRef] [PubMed]

211. Price, C.C.; Krebs, E. P-nitrobenzoyl peroxide. Org. Synth. 1943, 23, 65.

212. Her, B.; Jones, A.; Wollack, J.W. A three-step synthesis of benzoyl peroxide. J. Chem. Educ. 2014, 91, 1491-1494. [CrossRef]

213. La Barge, R.G.; Johnson, G.L. Preparation of Benzoyl Peroxide. U.S. Patent 3,674,858, 4 July 1972.

214. Wright, J.J.K.; Merill, Y.; Puar, M.S.; McPhail, A.T. Structure of oxanthromicin (antibiotic 16-550), a novel dimeric anthrone peroxide. J. Chem. Soc. Chem. Commun. 1984, 473-474. [CrossRef]

215. Patel, M.; Horan, A.C.; Gullo, V.P.; Loebenberg, D.; Marquez, J.A.; Miller, G.H.; Waltz, J.A. Oxanthromicin, a novel antibiotic from actinomadura. J. Antibiot. 1984, 37, 413-415. [CrossRef] [PubMed]

216. Otoguro, K.; Iwatsuki, M.; Ishiyama, A.; Namatame, M.; Nishihara-Tukashima, A.; Kiyohara, H.; Hashimoto, T.; Asakawa, Y.; Ōmura, S.; Yamada, H. In vitro antitrypanosomal activity of plant terpenes against trypanosoma brucei. Phytochemistry 2011, 72, 2024-2030. [CrossRef] [PubMed]

217. Tropina, V.I.; Krivykh, O.V.; Sadchikova, N.P.; Terent'ev, A.O.; Krylov, I.B. Synthesis and antimicrobial activity of geminal bis-hydroperoxides. Pharm. Chem. J. 2010, 44, 248-250. [CrossRef]

(C) 2017 by the authors. Licensee MDPI, Basel, Switzerland. This article is an open access article distributed under the terms and conditions of the Creative Commons Attribution (CC BY) license (http://creativecommons.org/licenses/by/4.0/). 